Portland State University

PDXScholar

Environmental Science and Management

Professional Master's Project Reports

2020

\title{
Effectiveness of Focused Water Conservation Messaging in the Clackamas River, OR
}

Rikki Carroll Oden

Portland State University

Follow this and additional works at: https://pdxscholar.library.pdx.edu/mem_gradprojects

Part of the Natural Resources Management and Policy Commons, and the Water Resource Management Commons

Let us know how access to this document benefits you.

\section{Recommended Citation}

Oden, Rikki Carroll, "Effectiveness of Focused Water Conservation Messaging in the Clackamas River, OR" (2020). Environmental Science and Management Professional Master's Project Reports. 64.

https://pdxscholar.library.pdx.edu/mem_gradprojects/64

https://doi.org/10.15760/mem.67

This Project is brought to you for free and open access. It has been accepted for inclusion in Environmental Science and Management Professional Master's Project Reports by an authorized administrator of PDXScholar. Please contact us if we can make this document more accessible: pdxscholar@pdx.edu. 
Effectiveness of Focused Water Conservation Messaging in the Clackamas River, OR

\author{
by \\ Rikki Carroll Oden
}

\begin{abstract}
A thesis submitted in partial fulfillment of the requirements for the degree of
\end{abstract}

Master of Environmental Management

Thesis Committee:

Max Nielsen-Pincus

Alida Cantor

Sarah Carvill

Christine Hollenbeck

Portland State University

2020 
Abstract

The Clackamas River in Oregon is a drinking water source for upwards of 300,000 people living in the Portland metro region. This river experiences seasonal low flow during the annual dry season throughout summer and early fall when endangered salmon species return to the river to spawn. This dry season also coincides with the highest period of urban water use. Since precipitation is minimal at this time, water users choose to water their lawns to make up for the lack of rain which contributes to water use tripling during the driest part of the year. To promote local water conservation, the Clackamas River Water Providers (CRWP) - who manage source water protection and public outreach and education around watershed issues, drinking water, and water conservation for the eight water providers on the river-have created a water conservation campaign that they intend to promote each dry season for the next several years. First promoted during the dry season of 2019, the messaging focuses on the flow needs of endangered salmon and asks water users to cease outdoor watering altogether. Through focus group discussion and a survey of water users, this research investigates public perception and opinion of the CRWP's summer water conservation messaging campaign with the goal of improving the effectiveness of the messaging in future dry seasons. 


\section{Contents}

Introduction 1

Chapter 1 - Water Conservation Messaging in the Clackamas River: What focus group research reveals about the political ecology of water and the adoption of water conservation behaviors ..........6

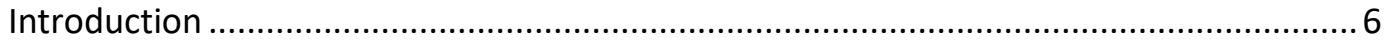

The Political Ecology of Drinking Water...................................................................... 6

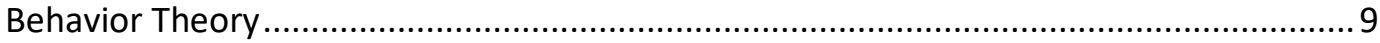

Case Study: The Clackamas River, Oregon ................................................................... 11

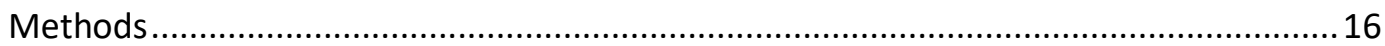

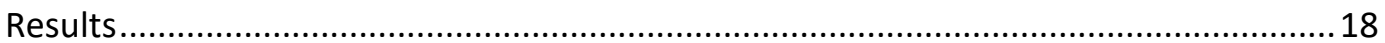

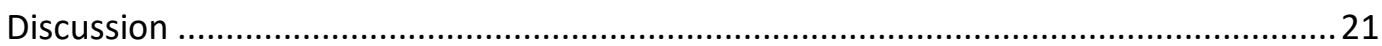

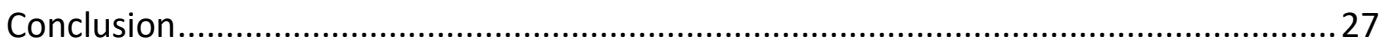

Chapter 2 - Environmental Concern and Local Water Conservation: How motivation acts as a mediator

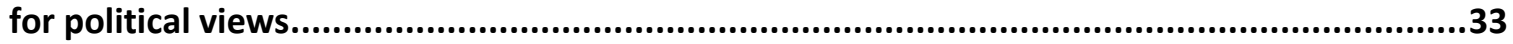

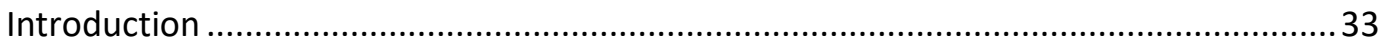

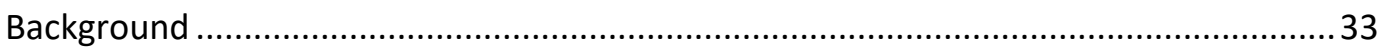

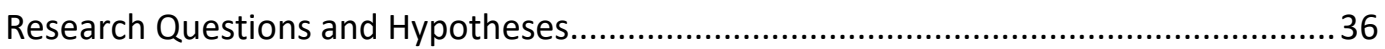

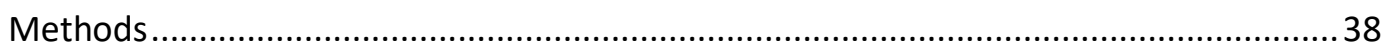

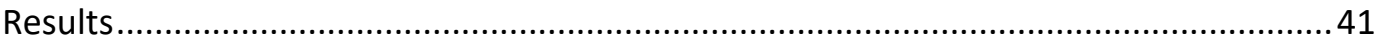

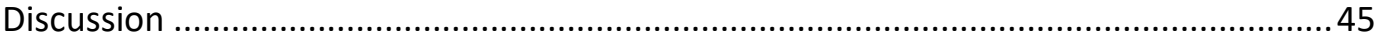

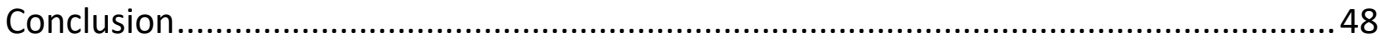

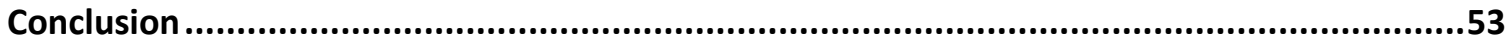

Appendix: Clackamas River Water Providers Summer Watering Campaign Assessment: Results from a

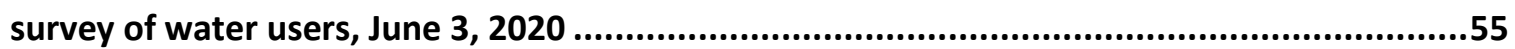

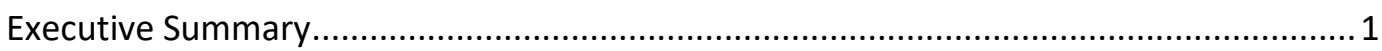

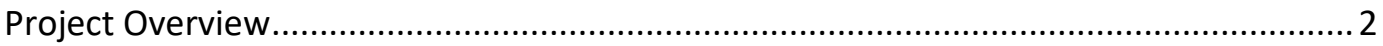

Survey Section 1: Awareness and Water Conservation Behaviors ................................... 5

Survey Section 2: The Summer Watering Campaign ................................................... 6

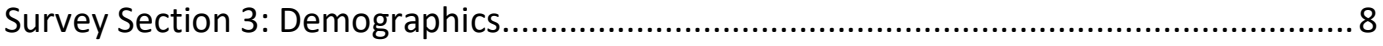

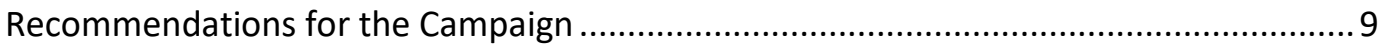

Appendix: Survey Results - Tables and Figures .............................................................. 11 


\section{Acknowledgements}

Many thanks to Dr. Max Nielsen-Pincus for his advising and support throughout this project, and to Kim Swan and Christine Hollenbeck at CRWP for the opportunity to work on a subject that I am truly passionate about.

Thank you to Dr. Alida Cantor and Dr. Sarah Carvill for building my theoretical knowledge and my writing skills, as well as for serving on my committee.

Thank you to Dr. Melissa Haeffner for her guidance and support during my first year in the program, and for helping me get involved in multiple valuable collaborative projects.

Thank you to my peers in the ESM Department who helped me get through coursework, gave feedback on my project at many different stages, and for generally being a trustworthy group who I could always count on for support.

And of course, thank you to my friends and family for encouraging me to follow my passion. 
Over the next several decades, water resources around the world will be affected by the changing climate (IPCC, 2018). Climate research is already finding evidence of altered water regimes that affect local peoples, plants, and animals (Crate, 2011). By understanding current water use trends and communicating any needs for water conservation, water providers can prepare for future changes to water supply. This research uses the Clackamas River watershed as a case study to understand the water conservation attitudes and behaviors of urban water users.

\section{Research objectives}

This research project is a collaboration between Portland State University and the Clackamas River Water Providers (CRWP), a coalition of the eight drinking water providers that all source their water from the Clackamas River. This research aims to understand Clackamas River water users' perceptions of CRWP's water conservation campaign as well as their attitudes and behaviors regarding water conservation. This campaign uses focused messaging to inform the local general public of water issues in the basin and asks water users to adopt water conservation behaviors, especially reducing their outdoor water use during the watershed's dry season, from August to October.

Through literature review, participant observation, focus group, and survey research, this project seeks to answer the research question what are the attitudes, beliefs, and behaviors of Clackamas River water users surrounding water conservation and how do they influence water conservation behaviors? The findings of this overall research project can be practically applied to watersheds across the US, and may help water managers communicate with their water users and create behavior changes to aid in supply management.

\section{Chapter 1 - Focus Group and Political Ecology}

The first chapter of this thesis reports the findings of the initial portion of the research project, where we collected data through focus group discussion with Clackamas River water users as well as through participant observation at meetings of local water provider organizations. The objective was to gain a foundational understanding of water users' perceptions of CRWP's summer watering campaign in order to guide the survey design, which was the next step of the project. We chose the method of a focus group because we believed it would be the best way to communicate information about the campaign and local water issues as a focus group would allow for the time and interactions between 
water users and water providers to ask and answer questions. The data gathered through focus group discussion and participant observation was analyzed through lenses of political ecology and behavior theory. By evaluating focus group participants' comments through the Theory of Planned Behavior (Ajzen, 1991) and the theory of the Diffusion of Innovations (Rogers, 1983), we are able to deconstruct water users' experience of choosing whether or not to adopt water conservation behaviors as well as any potential barriers that may stand in their way. Through political ecology themes of agency at different scales, avoiding regulation, knowledge creation, and collaboration, we are able to understand the interactions between humans and nature that shape the need for water conservation. The finding of strong collaboration amongst local water providers to ensure adequate supply during times of drought and to prepare for potential trend shifts due to climate change shows us that natural resource managers are making the effort to get ahead of the impacts of climate change.

\section{Chapter 2-Survey Results}

The second chapter of this project uses the results of the survey of Clackamas River water users to better understand the relationship between participants' perceived likelihood of completing water conservation actions with their political views and motivation. Past environmental campaign research shows a correlation between an individual's political views and their willingness to participate in environmental campaigns or projects. With the survey data, we found that motivation acted as a mediator between participants' political views and their perceived likelihood of acting to complete water conservation behaviors. This means that an individual's political views do not predict environmental concern as indicated by likelihood of acting to perform water conservation behaviors. An individual's motivation to conserve water was determined to be an important factor in predicting likelihood of acting to perform water conservation behaviors alongside their political views. This information can be used to understand water users across the U.S. and aid water managers in their messaging campaign efforts.

\section{Appendix - Report of Survey Findings for the Clackamas River Water Providers}

The purpose of the third chapter of this project is to summarize the survey findings for CRWP board members. This report describes the results of the survey conducted to understand public perception of their summer water conservation campaign and provides recommendations for future campaign improvements. CRWP board members received this report as part of a presentation I gave outlining my recommendations and reporting my findings. This chapter outlines three main methods: a 
literature review, the focus group, and the online survey. The report also breaks down the content and results of the survey in three sections.

The first section focused on awareness and water conservation behaviors. From these results we see a potential increase in source water awareness from a survey of the same population five years before. The second section of the survey focused on the summer water conservation campaign itself including a description of the campaign and questions asking participants about their motivation to participate and the likelihood of them doing various water conservation actions. In this section, we provided an explanation of the issues driving the need for the water conservation campaign to each participant. There were three different framings of this message, and we expected to see different responses to the campaign based on these framings, though analysis showed no differences in participants motivations or perceptions of the campaign due to the framings. The third section of the survey focused on the demographics of the participants. Based on responses, the participants in the survey were home owners (95\%) with a median household income of $\$ 112,499$ and a median age of 56 . Information about the participants' political views, home type, education, gender, and years lived in Clackamas County. The appendix of the report includes raw results of all survey responses. These results are presented in an appropriate figure or graph, as well as in tables that show the responses from the water provider groups so that the water providers can better understand their water users.

The final section of the report outlines recommendations to improve the campaign based on the findings from the literature review, focus group, and survey. Overall, I recommended increasing awareness of the campaign by focusing on the unique aspects of the watershed that drive the need for water conservation, addressing the different audiences in the watershed through multiple framings, and continuing public education efforts in schools and through the campaign's website. I also recommended monitoring public perception of the campaign in future summers, creating additional financial incentives to reduce water use, working with local HOAs to change policies during the dry months, and focusing on creating a cultural shift around the value of a green lawn. The specific messaging strategies behind the campaign could also be expanded, and a table of twelve types of messaging strategies and their definitions can be found in this section.

\section{The importance of this research project as a whole}

These three chapters represent different portions of a broader project that aims to understand water conservation attitudes and behaviors in urban water users. By starting with a focus group, we 
were able to spend time speaking to individual water users and communicate their role within the local water cycle while learning about their values. When analyzing the focus group and participant observation data, we were able to untangle the impacts agents have on each other at different scales within this watershed. We used these focus group findings to design our survey, which gave us even more information about water users attitudes and behaviors. We used this information to analyze the connection between water users' political views, their motivation, and their likelihood of completing water conservation actions. The survey results were also reported directly to the water providers themselves, enabling water managers to make informed decisions about local water use, water supply, and their relationship and communications with their water users.

The findings of this research can be practically applied to other urban watersheds across the United States, and perhaps internationally. By evaluating water use and management through a political ecology lens, the threads of agency and power can be better understood to make improvements to the system in any watershed. With knowledge of the political demographics within a service area, a water provider can predict how motivated their water users will be to conserve water, and how likely these water users could be to complete water conservation actions. By using different framings of a message and different messaging strategies, water providers can reach more audiences within their user population, increasing the changes of creating the desired behavior change. Increasing motivation to conserve, increasing the desire to act in order to benefit one's local environment, should be the aim of local water providers with water conservation needs.

Climate change will affect water trends and availability across the globe, and some watersheds will find themselves needing to conserve water. With the findings of this research, water providers are better equipped and informed to communicate with their water users and create a culture of water conservation based on the needs of their community. 


\section{Citations}

Ajzen, I. (1991). The theory of planned behavior. Organizational Behavior and Human Decision Processes, 50(2), 179-211. https://doi.org/10.1016/0749-5978(91)90020-T

Chen, J., \& Chang, H. (2019a). Climate and Land Use Change Impacts on Water Quality and QuantityClackamas Watershed Resilience Project (Poster). Portland State University, Department of Geography. https://drive.google.com/file/d/1uQszJvFfON1S5Ct9wN2lalq-20okPN9Q/view?usp=embed_facebook

Chen, J., \& Chang, H. (2019b). Projected Changes in river discharge and sediment load in Clackamas River Watershed. Portland State University, Department of Geography.

https://drive.google.com/file/d/1cV4Jho1XnepwynErHf935eYrlOxqKBI8/view?usp=embed_facebook

Crate, S. A. (2011). A Political Ecology of "Water in Mind": Attributing Perceptions in the Era of Global Climate Change. Weather, Climate, and Society, 3(3), 148-164. https://doi.org/10.1175/WCAS-D-10-

05006.1

Masson-Delmotte, V., Zhai, P., Portner, H. O., Roberts, D., Skea, J., Shukla, P. R., Pirani, A., MoufoumaOkia, W., Pean, C., Pidcock, R., Connors, S., Matthews, J. B. R., Chen, Y., Zhou, X., Gomis, M. I., Lonnoy, E., Maycock, T., Tignor, M., \& Waterfield, T. (2018). Summary for Policymakers (Global Warming of 1.5 oC). IPCC. https://www.ipcc.ch/sr15/chapter/spm/

Rogers, E. M. (1983). Diffusion of Innovations. Free Press. 


\section{Chapter 1 - \\ Water Conservation Messaging in the Clackamas River: What focus group research reveals about the political ecology of water and the adoption of water conservation behaviors}

\section{Introduction}

Over the next several decades, water resources around the world will be affected by the changing climate (Chen \& Chang, 2019a, 2019b; IPCC, 2018). Climate research is already finding evidence of altered water regimes that affects local peoples, plants, and animals (Crate, 2011). The way humans acquire, process, and distribute natural resources like water-which can be understood as the political ecology of water-will shift as precipitation trends and seasonal weather patterns change. In the Clackamas River watershed in Oregon, water agencies are looking ahead and planning for potential future supply fluctuations by evaluating their present-day water usage trends and vulnerabilities. Future supply may be uncertain, but some actors believe future demand can be manipulated and reduced through behavior changes of water users as promoted through messaging campaigns.

This paper explores the political ecology of drinking water and urban residential water use behaviors through a case study in the Clackamas River watershed in the Portland metropolitan region in Oregon. A coalition of water providers in this watershed, the Clackamas River Water Providers (CRWP), have designed and implemented the first season of what is planned to be a decade-long water conservation campaign that expresses a need to conserve water for endangered fish that spawn in the river during the dry season. Through literature review, participant observation, and focus group discussion, this paper seeks to understand water users' perceptions of CRWP's summer water conservation campaign and the ways in which agents influence each other's' power over water within the Clackamas River basin.

\section{The Political Ecology of Drinking Water}

Political ecology offers an effective lens through which the interactions between humans and natural resources can be studied. Political ecologists seek to recognize the power relations through which resources are both produced and distributed (Robbins, 2004). This approach offers both a hatchet and a seed, meaning the approaches of political ecology employ critical insights that can chop through 
the acceptance of an unchangeable world and also be used to develop claims of how the world should be (Loftus, 2009; Robbins, 2004).

Early explorations of water through political ecology were rooted in studying how the distribution of water has been shaped by relations of power, but more recent work focuses on the how water itself shapes those relations (Loftus, 2009). The predicted effects of climate change show changes in water availability which will only amplify the power water itself has in shaping human relations of power. Water can be powerful when it's overly abundant (for example, in New Orleans in 2005) and when it's scarce due to prolonged droughts or seasonal dryness (Swyngedouw, 2009). As more extreme weather patterns emerge due to climate change, scientists expect to observe an increase in flooding events and an increase in droughts (IPCC, 2018), which will change the way humans interact with and control water. This paper will explore four themes of political ecology-agency, avoiding regulation, collaboration, and the creation of knowledge-through a case study in the Clackamas River watershed in Oregon that will enable insight and understanding in a real-world setting.

\section{Agency at different scales}

The actions of the many actors who use and appropriate water resources in the West have permanently and irreversibly altered the hydrology, ecology, and geomorphology in many watersheds (Crifasi, 2002). These actors exist at multiple scales and include state and federal agencies at the broadest scale, municipal or private water providers at a smaller local scale, and water users at the individual scale. Collaboration occurring within these watersheds can be seen as a method of downward rescaling, since responsibility and decision-making is in the hands of municipalities and water providers (Cohen \& Bakker, 2014). These local actors and agents all interact with local water as a natural resource, though there is variation amongst the actors' agency over its use and their own behavior in relation to it. In the case of water, where rights and prior appropriation determine access and agency, select agents have the power to make decisions that affect all users, and a few agents can determine the fate of others in the watershed.

Though individual water users can be mandated to reduce or curtail their water use, this only occurs in extreme situations. Typically, individual water users are able to use as much water as they are willing to pay for, and water providers cannot raise prices at will. Additionally, water use trends set by individuals can affect water providers at the local scale, but water providers cannot mandate water 
restrictions until the supply of water reaches a certain low threshold. This is how water users and water providers have agency over each other at the individual and local scale.

\section{Avoiding regulation}

In Oregon, the state manages water quality through the Oregon Department of Environmental Quality (DEQ) and water quantity and rights through the Oregon Department of Water Resources (OR DWR, 2018; State of Oregon: Water Quality - Water Quality Standards, n.d.). Local organizations seeking to maintain their control over and access to local resources are motivated to avoid violating environmental policies because it could lead to stronger top-down regulation from the state, which would reduce their own local control. For this reason, local agents often create collaborative partnerships with other similar agents at the same scale who share their resource of interest in order to manage it with minimal impacts that might draw the attention of higher-level regulators. Examples of these collaborative approaches can be seen in the agriculture sector in Canada where farmers worked together to reduce detrimental environmental impacts in order to avoid regulation (de Loë et al., 2015) and in water governance in Montana where local water resource planning shifted to a model of "shared giving" (Anderson et al., 2016). Avoiding top-down regulation through local collaboration is a strategy seen across natural resource industries.

\section{Collaboration}

Due to a lack of comprehensive national water policy in the US, there is a trend of bioregional ecosystem-scale management approaches with an emphasis on shared governance in water management (Gerlak, 2008). An example of this shared governance is a management style known as collective water resource management. Collective water resource management (CRWM) is a collaborative method of watershed management where stakeholders work together to "solve" waterrelated problems (Anderson et al., 2016). This style of management shifts the scale of decision-making to the watershed (Cohen \& Bakker, 2014), which can be seen across Oregon in the form of watershed councils that were created by the state in 1993 (Watson et al., 2019). There are various reasons for and benefits to this style of management, and in the Clackamas watershed CRWM represents an attempt by local users to avoid the depletion and degradation of water resources they all depend upon (Anderson et al., 2016). Collaborative approaches to environmental problem solving are becoming increasingly common (Holley \& Sofronova, 2017) and can be seen across various natural resource industries at different scales all over the world. 


\section{Creation of knowledge}

Political ecology enables the demonstration for the ways in which environmental "problems" are constructed. These problems arise from natural events like droughts or floods and are only considered to be "problems" because they negatively affect humans. For this reason, environmental problems are rooted in the political-economic systems that produce and sustain them (Robbins, 2004).

Knowledge of the local environment and awareness of environmental problems is crucial to understanding them. There are movements within the field of political ecology that push for the inclusion of local knowledge alongside agency practices in environmental management processes (Robbins, 2004). In some cases, local knowledge and agency practices have stark differences, and the ecology -in addition to the human interaction with the ecology-becomes political within the context of local knowledge (Perramond, 2005). In other cases, local knowledge and agency practices can be combined to create knowledge in a specific place. In the case study discussed in this paper, we will explore the ways in which a water provider partnership uses the creation of knowledge to influence the behavior of their water users and reduce the impacts of the environmental problem of low supply.

These four themes within political ecology-agency, avoiding regulation, collaboration, and the creation of knowledge-are present in the case study region and can be used alongside behavior theories to understand the interactions between humans and nature that shape the need for water conservation.

\section{Behavior Theory}

Psychologists have developed numerous theories to explain people's behavior and behavior changes. Both the Theory of Planned Behavior (Ajzen, 1991) and the theory known as the Diffusion of Innovations (Rogers, 1983) have been extensively utilized to evaluate pro-environmental behavior changes (Chan \& Bishop, 2013; Sengupta et al., 2005; Warner et al., 2016; Zhong et al., 2019).

\section{Theory of Planned Behavior}

The Theory of Planned Behavior (TPB) is used to explain all behaviors over which people have the ability to exert self-control. According to TBP, behaviors are a result of an individual's intentions. Intentions are determined by three components: attitudes, or the individual's overall evaluation of the behavior; subjective norms, or the individual's beliefs about whether others think they should engage in the behavior; and the extent to which the individual perceives they have personal control over the 
behavior (Conner, 2001). TPB is often used in heath behavior studies but is easily transferrable to the context of pro-environmental behaviors and water conservation.

The importance of intentions and its components emerge when TBP is applied to proenvironmental behaviors and water conservation. Though the intention to engage in pro-environmental behaviors may exist, these behaviors are not always realized. Research has shown that people feel

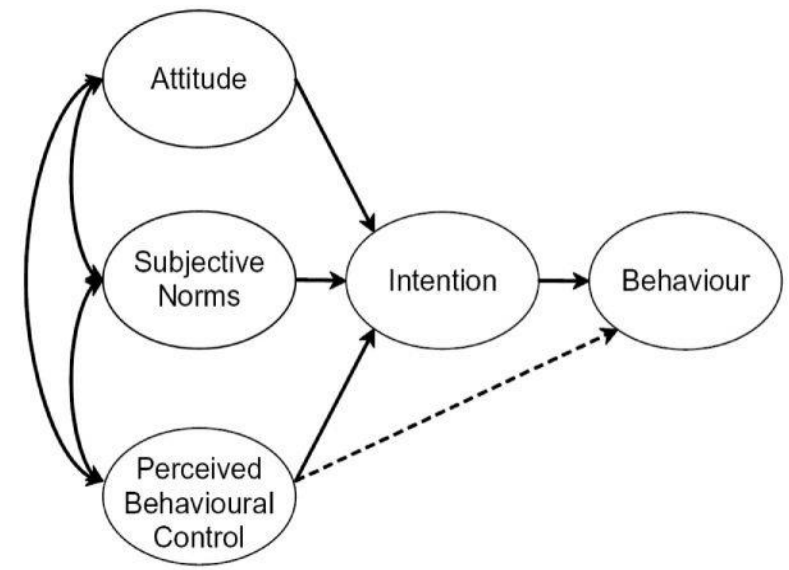

Figure 1. The components of the Theory of Planned Behavior (Aizen, 1991). responsible for water conservation, but they do not always follow water conservation practices, meaning that their sense of responsibility is not manifesting as a practiced behavior (Miller \& Buys, 2008). Results like these demonstrate the importance of one component of TPB, personal behavioral control (PCB). PCB is an important component of this theory due to the nature of water conservation being a large problem that no single individual can fix. Individuals need to feel that the efforts they make are helping, thus when personal efficacy is perceived as low, people don't feel like their individual actions contribute enough (Thompson \& Stoutemyer, 1991) and they may disengage from conservation behaviors. In general, regardless of how much an individual values the environment, research shows that people are inconsistent in their environmental behaviors (Steg \& Vlek, 2009).

\section{The Diffusion of Innovations}

Water conservation is not a new idea, but the initial adoption of water conservation behaviors or technologies by an individual can be understood through the theory of the Diffusion of Innovationsspecifically the innovation-decision process (Rogers, 1983). An individual goes through the innovationdecision process when they are exposed to a new innovation or idea and choose to adopt or reject it. The innovation-decision process has five stages: Knowledge, Persuasion, Decision, Implementation, and Confirmation. In some cases, an individual may learn of an innovation and decide they want to adopt it in order to fulfill a need they may or may not have been aware of previously. Though exposure to an innovation will have minimal effect unless the individual perceives the innovation will fulfill a need and aligns with their attitudes and beliefs (Hassinger, 1959). If knowledge about the innovation does not 
align with an individual's attitudes and beliefs, they may experience cognitive dissonance (Festinger, 1962) and may attempt to reduce this uncomfortable state through selective exposure or selective perception. Selective exposure occurs when an individual avoids messages that are in conflict with their predispositions; selective perception is a tendency to interpret communication messages in terms of one's attitudes and beliefs (Rogers, 1983).

Table 1. The definitions of the five stages of the innovation-decision process and their context within the CRWP's water conservation campaign (Rogers, 1983).

\begin{tabular}{|l|l|l|}
\hline Stage & Definition & Campaign Context \\
\hline Knowledge & $\begin{array}{l}\text { Exposure to an innovation's } \\
\text { existence and functions. }\end{array}$ & $\begin{array}{l}\text { Providing awareness of the need for } \\
\text { conservation due to naturally low water } \\
\text { levels, increased watering, endangered fish, } \\
\text { and regulations. }\end{array}$ \\
\hline Persuasion & $\begin{array}{l}\text { Formation of a favorable or } \\
\text { unfavorable attitude towards } \\
\text { the innovation. }\end{array}$ & $\begin{array}{l}\text { Assessing how conservation aligns with } \\
\text { personal attitudes, values, and PBC. } \\
\text { Evaluating possible methods for the } \\
\text { individual. }\end{array}$ \\
\hline Implementation & $\begin{array}{l}\text { Engagement of activities that } \\
\text { lead to the choice to adopt } \\
\text { or reject the innovation. }\end{array}$ & $\begin{array}{l}\text { Formulating a plan or strategy for } \\
\text { conservation, signing the pledge card, } \\
\text { purchasing water-saving devices. }\end{array}$ \\
\hline innovation to use. & $\begin{array}{l}\text { Ceasing outdoor irrigation, installing water- } \\
\text { saving devices, adopting water saving habits } \\
\text { and behaviors, displaying campaign yard sign. }\end{array}$ \\
\hline Confirmation & $\begin{array}{l}\text { Continuation of information- } \\
\text { seeking after the decision } \\
\text { has been made. Could result } \\
\text { in the reversal of the } \\
\text { decision. }\end{array}$ & $\begin{array}{l}\text { Paying less for their water bill, dormant lawn } \\
\text { becoming green at the beginning of the rainy } \\
\text { season, no harm occurred due to water } \\
\text { conservation practices. }\end{array}$ \\
\hline
\end{tabular}

These two behavior theories can be applied to urban residential water users in our case study area to help understand the potential success of a water conservation messaging campaign, which is one way that water providers can influence the behavior of their individual water users.

\section{Case Study: The Clackamas River, Oregon}

The Clackamas River in Oregon is a drinking water source for over 300,000 people and is home to several species of endangered salmon. Multiple agencies are involved in the management of this river and watershed, and the agent central to this research is an organization called the Clackamas River Water Providers (CRWP). CRWP is a coalition of the eight drinking water providers that source their water from the Clackamas River. This organization clearly states that its purpose is to fund and coordinate source water protection efforts as well as public outreach and education regarding watershed issues, drinking water, and water conservation (Clackamas River Water Providers / About Us, n.d.). 
This coalition of water managers faces multiple challenges in this watershed. The Clackamas River has no storage reservoirs, though there are two run-of-the-river dams used for power generation. This means water managers have no way of holding water in the river; they are only able to withdraw water from whatever quantity is in the river at a given time. They also face flow level fluctuations throughout the year due to the hydrology of the basin. The Clackamas River is primarily fed by snowpack and groundwater. Throughout the year, snow melts and feeds the river through the groundwater table. By the summer months, there is less input into the river and flow is at its lowest. The summer months also feature the lowest amount of precipitation which drives urban water users to irrigate their lawns and gardens and increase their overall water use for the season. In fact, summer water use is between 2 and 3 times the amount used during the winter months because of increased landscape irrigation (Clackamas River Water Providers / Water Efficient Plant Guide, n.d.). For these reasons, late summer is a critical time of year for water managers because it is the season when extremes meet: natural input is at its lowest and withdraw is at its highest.

Clackamas River water managers are concerned about climate change exacerbating low summer flows. Over the last few years, CRWP has been involved in a climate resiliency study with Portland State University to better understand the impacts of climate change within the watershed. This project, known as the Clackamas River Watershed Resilience Project, aims to assess changes to wildfire risk and future water supply due to climate change in order to inform managers and aid in planning for the future (Nielsen-Pincus et al., 2018). Involvement in this climate change impact study shows that CRWP is a forward-thinking organization, as they are using the results to look ahead and determine the changes they can make in the present regarding infrastructure, management strategies, and public education that will benefit them in the future.

Additionally, CRWP is planning and preparing for the future enforcement of currently unenforced minimum flow regulations. The Clackamas River is unique in the area because it is one of the last local rivers that is both used for drinking water and is home to endangered salmon during spawning season. Figure 2 shows that migrating or spawning salmon can be found in the river virtually year-round (Clackamas Fish Runs - Fish Counts \& Fish Runs / PGE, n.d.). But because flows are lowest during the summer, and salmon need a minimum amount of water in the river in order to swim upstream against the current to spawn, minimum flow requirements have been designated to the river during specific summer months. (Swan, 2019). Though these requirements rights were attached to CRWP's water right 


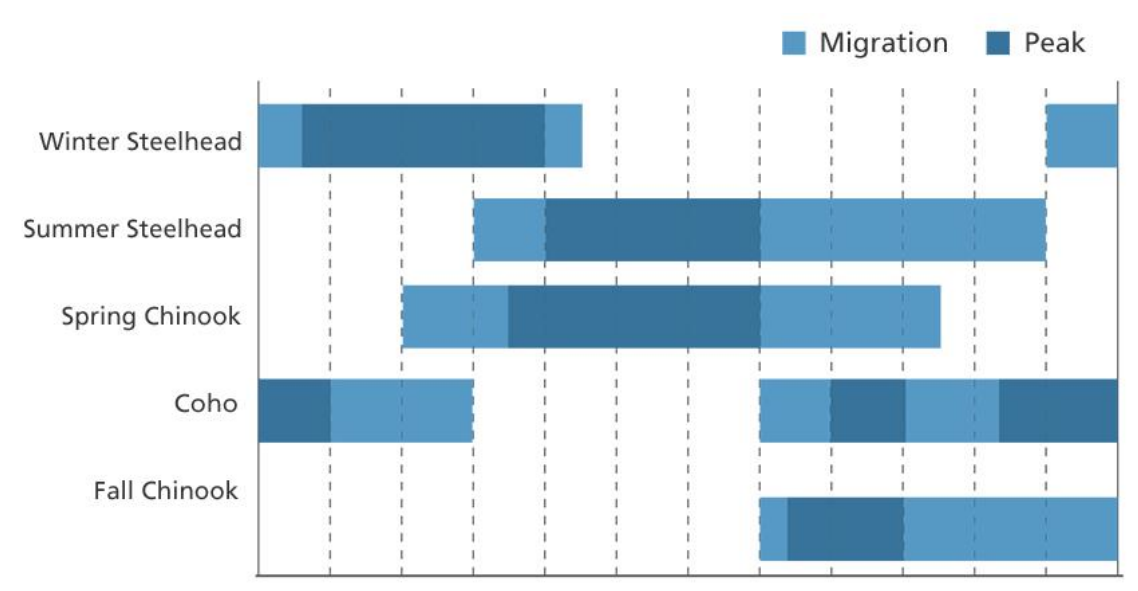

JAN FEB MAR APR MAY JUN JUL AUG SEP OCT NOV DEC

Figure 2. This diagram shows the five different salmon species that live and spawn in the Clackamas River ("Clackamas Fish Runs--Fish Counts \& Fish Runs ( PGE." n.d.)

in 2004, they were challenged in court and are still being reviewed. For this reason they have not been enforced yet, but the summer of 2015 was particularly dry and water managers in the Clackamas had a "wake up call" when they experienced the problem of significantly low flows and recognized the high probability of the same situation occurring in the near future, especially with the potential effects of climate change to water supply (Swan, 2019). There were no regulatory consequences in 2015, but CRWP continues to be proactive by looking forward to the future and acting to get ahead of potential problems.

\section{Water Conservation Campaign}

As part of their preparations for anticipated low flows during future summers, CRWP created a water conservation campaign that premiered in August of 2019 (Figure 3). A common strategy to create behavior change is the use of focused messaging campaigns that inform the general public of an issue and attempt to create a specific behavioral change. The messaging of the CRWP's campaign focuses on the endangered salmon that live in the Clackamas River and features the slogan "Fish on the run, irrigation done!"(Clackamas River Water Providers / Fish On The Run, 2019). The goal of the campaign is to reduce water use during the summer months primarily through the reduction of outdoor watering. Water users are encouraged to sign pledge cards that include a checklist of ways they plan on conserving water that are primarily irrigation-oriented but also include indoor water conservation strategies. Water users who complete pledge cards receive a yard sign with the campaign slogan and website on it that can help explain their brown dormant lawn to neighbors. 
The campaign is designed to run during dry summer months when the need for water conservation is highest, then to be quietly shelved during the wet parts of the year so water users don't become desensitized to the message. CRWP plans to run this campaign for the next decade under an

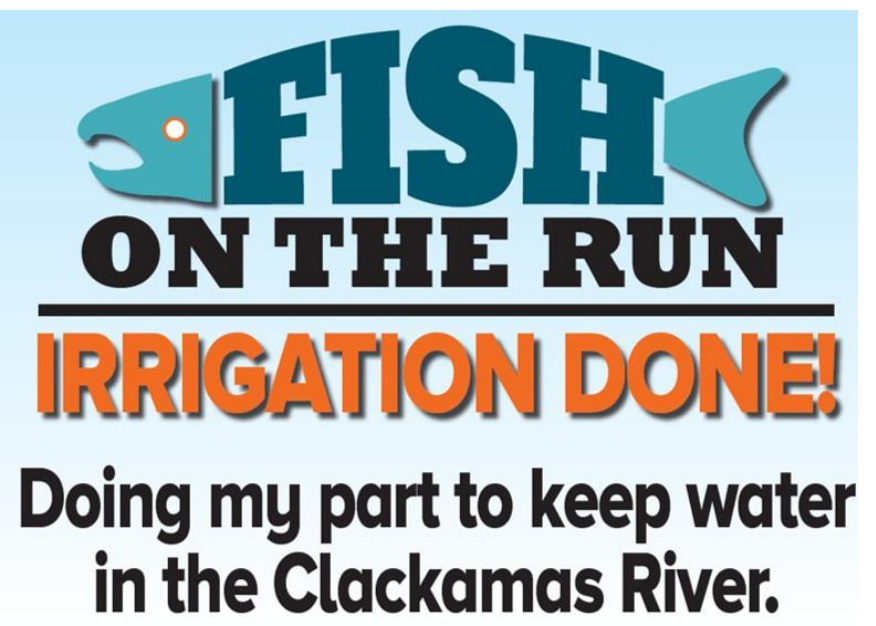

Figure 3. CRWP's campaign graphic for their summer water conservation messaging campaign ("Clackamas River Water Providers / Fish On The Run," 2019). adaptive management strategy, meaning improvements and adjustments can be made each year to ensure the message is as effective as possible. In its first year of circulation, the campaign was promoted through radio and local newspaper advertisements, in-person public outreach, as well as within various municipal newsletters distributed in the service areas. CRWP did not have a large budget for promoting the campaign and would have expanded this effort if funding was available.

It's important to note that this campaign is one of many ways that CRWP addresses water conservation needs; the organization offers public education programs to local schools, rebate programs, information about landscaping, free water-saving devices like shower heads and hose nozzles, as well as many educational materials on their website.

A common strategy to create behavior change is the use of specific messaging campaigns that inform the general public of an issue and attempt to create an intended behavioral change. This is commonly used to create pro-environmental behavior change in the form of resource conservation like water and electricity. Liang et al (2018) identified the major messaging types used to encourage water conservation behaviors during a long-term drought in California. They identified twelve different types of messaging (Table 2). The strategies that CRWP's campaign slogan utilizes are conservation tips, direct request, and commitment. The second half of the slogan ("irrigation done") is a direct request for consumers to cease outdoor irrigation and is a method or conservation tip. The pledge card acts as a way of committing to the requested behavior change. Campaign resources like the website and pledge cards also utilize referrals and redirections, policies, and loss aversion. The website offers many resources in the form of conservation information, tips and methods, and even rebate programs. The 
Table 2. Twelve typologies of message strategies identified by Liang et al (2015).

\begin{tabular}{|c|c|}
\hline Message strategy & Conceptual definition \\
\hline Conservation tips & $\begin{array}{l}\text { Conservation tips refer to messages that directly provide the receiver with any } \\
\text { type of content, tips, and strategies to save water. }\end{array}$ \\
\hline $\begin{array}{l}\text { Referrals and } \\
\text { redirections }\end{array}$ & $\begin{array}{l}\text { The referrals and redirections strategy refers to messages that aim to direct the } \\
\text { receiver to another source of information which serves as a means for the } \\
\text { audience to learn more about conservation. }\end{array}$ \\
\hline Policies & $\begin{array}{l}\text { Policies are any rules, regulations, laws, mandatory restrictions, and monetary } \\
\text { exchanges for some conservation actions. }\end{array}$ \\
\hline Goal-setting & $\begin{array}{l}\text { Goal-setting refers to providing the receiver a clear reference point in their } \\
\text { conservation behavior in an effort to achieve or surpass that point }\end{array}$ \\
\hline Loss aversion & $\begin{array}{l}\text { Loss aversion occurs when a message conveys to the receiver that inadequate } \\
\text { conservation efforts will result in a reduction in water supply and other related } \\
\text { consequences. }\end{array}$ \\
\hline $\begin{array}{l}\text { Evidence of } \\
\text { drought }\end{array}$ & $\begin{array}{l}\text { Offers some concrete evidence, often in data or pictorial elements, to encourage } \\
\text { conservation behavior. }\end{array}$ \\
\hline Social identity & $\begin{array}{l}\text { Social identity is a message strategy that heightens the awareness of the } \\
\text { receiver's group membership and makes salient his/her group-level } \\
\text { characteristics in favor of the desired outcome. }\end{array}$ \\
\hline Humor & $\begin{array}{l}\text { Humor attempts to gain attention by inducing a receiver's positive reaction or } \\
\text { arousal. }\end{array}$ \\
\hline Direct request & $\begin{array}{l}\text { The direct request strategy refers to water conservation messages that instruct } \\
\text { the audience to conserve without any support or justification. }\end{array}$ \\
\hline Commitment & $\begin{array}{l}\text { Commitment asks the receiver to demonstrate a willingness to conserve water, } \\
\text { privately and/or publicly. }\end{array}$ \\
\hline Social norms & $\begin{array}{l}\text { Social norms refer to the subjective and generalized belief that individuals have } \\
\text { about the referent others in their social environment. }\end{array}$ \\
\hline Social comparison & $\begin{array}{l}\text { Social comparison is a framing strategy that makes a direct evaluation of the } \\
\text { receiver against a certain referent individual (or group) in the attempt to induce } \\
\text { behavioral change in alignment with the referent individual (or group). }\end{array}$ \\
\hline
\end{tabular}

slogan references the minimum flow requirements for endangered salmon, but these policies aren't explained further on the campaign website. An explanation of this may be included at a later time.

Ideally, CRWP would like to be able to utilize messaging strategies that capitalize on existing social identity and social norms, but neither of these are very strong within the watershed and community at this time. The CRWP's strategy of using a unique quality of the watershed and targeting only locals who use water from the Clackamas has potential to be an effective strategy. The watershed itself can serve as a potent material and symbolic site for identification (Druschke, 2013) but social identity in this area is not strongly tied to the watershed, and many water users don't even know their water comes from the Clackamas River (Larson, 2019). Increasing awareness of the River as people's water source may increase the value people place on the watershed and demonstrate its significant impact on their lives. Communicating that water conservation in the Clackamas River is relevant and an issue of interest to local water users would help contribute to improved conservation long-term; 
messages that are relevant can result in longer-lasting changes in attitude (Petty et al., 1995).

Understanding the values of individuals in the watershed will help the CRWP tailor their messaging and improve the effectiveness of the campaign, which is why this research project is crucial to the future success of water conservation efforts within the Clackamas River watershed.

\section{Methods}

\section{Participant Observation}

In order to gain insight and understanding about the local water resource management sector, I attended various meetings and events during the course of this research project. Most of this time was spent with CRWP at board meetings, events promoting the water conservation campaign, and meetings discussing and planning this research project. I also attended a meeting with the Regional Water Providers Consortium (the Consortium). This organization was founded in 1997 to "improve the planning and management of municipal water supplies" and is made up of 23 water providers (About Us, 2014). This group has created plans for regional water supply, source water protection, and population growth (Regional Coordination, 2014).

\section{Focus Group}

The primary data gathering method for this research project was a focus group conducted with an involved set of stakeholders and ratepayers for water utilities associated with the Clackamas River Water Providers. The intention of the focus group was to create an opportunity to discuss the messaging campaign with engaged community members. It was thought that explanations would be most effective in person where the community members could ask questions, engage in dialogue, and explore different perspectives.

The focus group was designed to engage local water users and discuss their perceptions of the water conservation campaign. Potential participants were identified by CRWP board members and were chosen because they were active members of their community. This pool of potential participants was contacted and invited to participate in a focus group, and the scheduling of the focus group was based on participant availability. The focus group was held on the evening of October $8^{\text {th }}, 2019$ in a relatively central location. Seven people representing six different water providers attended the focus group. Though all participants were involved with their municipal government in some way, most volunteered in non-water-focused groups or committees. Of the seven total participants, two people had past or present experience working within the local water sector. 
Table 3. The focus group questions organized into four topics: awareness of the issues, perception of the campaign, motivation for action, and barriers to action. Topic questions (bolded) were projected for all participants to see.

\begin{tabular}{|c|c|}
\hline Discussion Topic & Main question and probing questions \\
\hline $\begin{array}{l}\text { Awareness of } \\
\text { the issues }\end{array}$ & $\begin{array}{l}\text { When you think about water conservation for the Clackamas } \\
\text { River, what are the important issues that come to mind? } \\
\text { - Were you aware of the flow minimums in the river before now? } \\
\text { - Whose job is it to make sure we have a sustainable, high quality } \\
\text { water supply (consumers, cities, state water managers, utilities, } \\
\text { agriculture, landowners, etc.)? } \\
\text { - How does water conservation rank in relation to other important } \\
\text { values in your life, and can you imagine anything that would } \\
\text { elevate the importance of water conservation in your life? } \\
\text { - Do you already take any specific actions to try to conserve water, } \\
\text { especially in the late summer? }\end{array}$ \\
\hline $\begin{array}{l}\text { Perception of } \\
\text { the campaign }\end{array}$ & $\begin{array}{l}\text { What do you think about the CRWP water conservation campaign } \\
\text { messaging and how it is focused on the fish-specific importance of } \\
\text { water conservation? } \\
\text { - What do you think about the look and feel of the messaging? The } \\
\text { slogan itself? } \\
\text { - How do you think the fish focus might impact the way people in } \\
\text { the watershed feel about the campaign? } \\
\text { - Are there other issues you think should be included in the } \\
\text { campaign? } \\
\text { - Is there anything you can think of that might elevate people's } \\
\text { perception of the campaign among the broader public? }\end{array}$ \\
\hline $\begin{array}{l}\text { Motivation } \\
\text { for action }\end{array}$ & $\begin{array}{l}\text { If you, or your neighbors, were asked to change your water use to } \\
\text { support CRWPs summer water conservation campaign, what do } \\
\text { you think would be motivating to take action? } \\
\text { - Are incentives important (e.g., free consultations, rebates for } \\
\text { equipment, etc.)? } \\
\text { - Are there knowledge gaps that are important to fill? } \\
\text { - Is there a particular type of messaging that might resonate better } \\
\text { than others? } \\
\text { - Does the geography of the Clackamas River matter? Would it be } \\
\text { all the same if CRWPs messaging was broader than the Clackamas } \\
\text { (e.g., the Willamette or Columbia basins)? }\end{array}$ \\
\hline $\begin{array}{l}\text { Barriers to } \\
\text { action }\end{array}$ & $\begin{array}{l}\text { What barriers or other issues do you see that stand in the way of } \\
\text { getting people to take action on water conservation? }\end{array}$ \\
\hline
\end{tabular}


Focus group discussion questions were organized into four primary sections: awareness of the issues, perception of the campaign, motivation for action, and barriers to action (Table 3). These questions were designed to spark conversation and to reveal participants' values regarding water use and the environment. The questions sought information from the participants about their values, perceived behavioral control, perceptions of their communities' values, and their knowledge of water conservation practices in order to evaluate the participants through the Theory of Planned Behavior and the Diffusion of Innovations (Ajzen, 1991; Rogers, 1983). Probing questions were prepared and readily available to the moderator if the conversation strayed from the main topic or lacked desired detail. Additional time was allotted at the end of the focus group for an open-ended discussion and for participants to share any additional thoughts or ideas.

As participants arrived, they were invited to eat the food provided and briefly socialize which helped establish an informal friendly atmosphere for the discussion. The focus group started with introductions from each researcher and participant including name, water provider, and the reason they think water conservation is important. This activity helped to break the ice and also gave the researchers insight into each participant's values and motivations. Next, a brief presentation was given that provided background information about the Clackamas River watershed, issues faced within the watershed, and the conservation campaign. The participants were then given time to review campaign materials including magnets, signs, and pledge cards. The rest of the time was spent discussing the focus group questions which were projected on a large screen, enabling participants to understand the goals of the discussion (see Table 3). A designated note-taker took detailed notes throughout the discussion and created a loose transcript with several direct quotes from participants.

At a later date, the detailed notes were used to evaluate the focus group through thematic analysis. The detailed notes and quotes were reviewed. Key comments and quotes were highlighted and categorized into topics. Similar topics were then grouped into larger themes which were connected to ideas in political ecology and behavior theory.

\section{Results}

\section{Participant Observation}

CRWP is a small organization with only two full-time employees who report to the board. Each board member is an employee of one of the water providers and these individuals take on their roles as members of the board as an additional duty to their standard work. CRWP employees act as 
representatives for their eight water provider members at local and regional meetings. During local events within the distribution jurisdiction, CRWP employees and volunteers promote water conservation directly to water users by providing information as well as water-saving devices like lowflow nozzles for garden hoses. CRWP is part of several collaborative environmental work groups within the watershed and region, and actively participates in projects along with non-profits, watershed councils, government agencies, and more.

At the meeting I attended in November 2019, the Consortium was discussing new water conservation technologies for water providers to adopt as well as methods to streamline member organizations' Water Management and Conservation Plans (Regional Water Providers Consortium, 2019). The goal is to create a plan for future curtailment events by finding the differences and similarities between plans, determine who best to communicate with, and to compare and be aware of each providers' triggers for different stages of curtailment. This discussion is important to these water providers because there is no specific trigger for curtailment set by the state; each provider has unique infrastructure and supply systems that determine the trigger point for curtailment stages. These local water providers are collaborating to streamline the overall curtailment process and reduce negative impacts that would potentially be felt by water users.

\section{Focus Group}

During the focus group discussion, participants learned detailed background information about the campaign as well as water resource issues in the Portland metro region and issues specific to the Clackamas River. Several themes emerged throughout the focus group discussion: personal efficacy, individual values, and awareness.

According to behavioral theories, an individual's values influence their intentions and behavior. The focus group participants had differing individual values regarding the endangered salmon, the environment, and the local community of water users. When asked about the use of the endangered salmon as the focus of the campaign slogan, a participant (Clackamas resident, 55 years old, female identified) asked "Why is it that the fish are more important than the people?" The group discussed the importance of conserving water for the fish but also for the present and future community. When the participants were asked if they thought the fish-focused messaging would resonate with their neighbors and local friends, one participant said "I care about fish, but I'm not sure that resonates with a greater number of people" (Oak Lodge resident, no water sector experience, 60 years old, female identified). 
She perceives her personal environmental values to be stronger than others within the community, meaning the fish-focus might be motivating to her, but would not be enough for others to adopt water conservation behaviors. Another participant was indifferent to the fish focus of the messaging and valued planning for the future more so than present-day fish protection. Regarding this value, he said "we need to act now so we don't have to act later. Spend a dime, save a dollar" (Oregon City resident, employed in water sector, 55 years old, male identified). Focus group participants demonstrated they valued the environment, the endangered salmon, and the present and future community.

Personal efficacy was another theme mentioned multiple times throughout the discussion. One participant often drives by a large local retirement community that has a large area of landscaping covered green grass. She said:

"[The retirement community]'s irrigation system is on all the time. It's raining and the irrigation is on! And people are driving up River Road thinking 'what good is my little postage stamp of a property? Why should I conserve?'” (Oak Lodge resident, community organizer, 65 years old, female identified).

The group discussed the potential mechanisms for reducing water use at facilities like the retirement community, industrial operations, agricultural properties, and even municipal properties in order to ensure all water users in the community - and not just residential water users - were participating in conservation. Another participant mentioned he has a green lawn in his front yard but he lives in a Home Owners Association (HOA) managed community. The HOA pays for and manages the landscaping of all front lawns within the neighborhood. He stated that he would only be able to let the grass in his backyard go dormant, as he doesn't have control over watering in is front yard, and that he would not be able to demonstrate his participation in the campaign with a yard sign. He said, "I can't put up the yard sign. My HOA. I can only have a sign for two months," (Estacada resident and City Council Member, 40 years old, male identified). Though these individuals were motivated to adopt water conservation behaviors, they had low personal efficacy or personal behavioral control.

The theme that was discussed most during the focus group was a lack of awareness and a need for education regarding water issues in the area. One participant stated he notices a lack of stewardship in people today and that we "have to change the culture" in order to improve water conservation (Happy Valley resident, works in water sector, 55 years old, male identified). Participants agreed that education should start with children. A CRWP representative briefly outlined the components of the 
organization's public education program, which included giving lectures at local schools. The group discussed the difference between areas where awareness of water conservation needs is strong due to long droughts and dry climates, like Southern California. One participant mentioned that the local area receives a lot of precipitation for the majority of the year, but "we have a drought season," which occurs every summer (Oregon City resident, employed in water sector, 55 years old, male identified). The group discussed the importance of and methods to create public awareness of the local 'drought season.'

\section{Discussion}

The case study of drinking water and water conservation in the Clackamas River, Oregon illuminate ideas from behavior theory and political ecology. These themes can be used by the CRWP to improve their water conservation messaging for future seasons, as well as other water providers and natural resource managers who aim to create a behavior change.

\section{Collaboration amongst agents at different scales to avoid regulations}

Based on data gathered through participant observation, there is strong collaboration between water providers at the local scale in the Portland metro region aiming to avoid top-down regulations. The Consortium is working to streamline the water conservation management plans (WCMP) of their member organizations in order to avoid potential increased top-down regulations. This last point is the most important because there is no specific trigger for curtailment set by the state; each provider has unique infrastructure and supply systems that determine the trigger point for curtailment stages. Because water providers have different triggers and sources, one water provider may be close to a trigger when others are not. Local water providers collaborate to avoid state intervention during these times by selling water to each other when possible. These non-standard water sales and the transactional costs associated with this collaboration are seen as a better alternative than state involvement and the triggering of curtailment procedures. The involvement of these 23 water providers in this Consortium and curtailment plan streamlining process is evidence of the collaboration occurring at the local agency scale with the goal of avoiding top-down regulations.

CRWP's water conservation messaging is aimed at actors within the individual water user scale. These individual actors have little agency because they lack the direct regulatory powers of water providers and agencies. However, their demand for water shapes the behavior of the actors above them in the form of resource production and distribution. The Clackamas River has no drinking water storage and water providers take water from the river to meet the demand of the consumers. If water providers 
are unable to meet this demand, they may want to use economic motivations to decrease water use by raising water rates. Unfortunately for most water utilities, the public needs to vote to approve a rate raise, and they often vote against proposed measures. Water providers must then use other methods to decrease demand or increase supply. In this way, the behaviors at the individual water user scale influence the behaviors at the local agency scale.

The use of CWRM as a management strategy in the Clackamas River watershed is evidenced by the existence of CRWP. These 8 water providers understood their shared reliance on the same body of water and developed a mechanism for collaboration in the form of the organization itself. The water providers identified their shared used of the River and recognized that pooling financial and political resources to manage it would benefit all of them. Though the individual water providers still manage their own distribution of the water, their source water protection program and public education programs are a collective effort managed by CRWP. By creating the water conservation messaging campaign, the member organizations are striving to avoid top-down regulation from state and federal agencies. CRWP knows that less water in the river during spawning season will result in more attention from the agencies that regulate their use of the Clackamas River, but through preemptive action CRWP and its members are able to make decisions about their own actions that will satisfy regulators' requirements without intervention from these regulators. Through collaboration within CRWP, local actors are holding on to their agency regarding their behaviors in the watershed.

CRWP is not the only organization promoting water conservation in the greater Portland area, and they must collaborate with the other local water provider groups to avoid negative impacts to all the water providers. The Consortium has their own water conservation messaging designed to promote general water conservation behaviors and reach a broad audience (Conservation, 2014). The City of Portland Water Bureau also promotes water conservation (Water Efficiency / The City of Portland, Oregon, n.d.) and is arguably the water provider with the most well-known water source. The Bull Run watershed has a strong presence in local culture and public awareness regarding local drinking water sources and many people in the Portland metro region believe the Bull Run is the source of their drinking water, even if they are served by a different water provider using a different source. This lack of awareness can create confusion for water users when drinking water enters the news cycle-whether the issue is water conservation, boil water notices, or maintenance issues-and one water provider's announcement can create confusion in the general public. When the issue is general water 
conservation, water managers see the resulting phone calls to their office as a simple inconvenience, but when the issue is relevant to human health, confusion about the affected water utility amongst the general public can lead to widespread panic. If a situation like this occurs, water managers have no choice but to put time and energy into communication efforts which reduces the resources available to address the actual problem. Collaboration and communication within the members of the CRWP and other local water providers are crucial to reducing public confusion and effectively manage water supply in the region.

\section{Behavior theory and water conservation}

Behaviors are shaped by an individual's values, their perceptions of their community's values, and their PBC (Ajzen, 1991; Rogers, 1983). The campaign focuses on conserving water to protect endangered fish, calling upon environmental values to drive behavior change. But the focus group demonstrated that strong environmental values were not the only values that could produce the desired behavior change. Valuing the preservation and protection of resources for present and future use by people coupled with the information that local water supply has a dry season was enough for some focus group participants to declare an intention to change their behavior. Finding ways of delivering the water conservation message that calls upon multiple values to create the same desired behavior change would be an effective solution for this messaging campaign.

When the focus group began, the participants were not impressed with the slogan of the campaign and generally didn't feel motivated by the focus on endangered salmon species. As their awareness of the issues and regulations in the basin increased, their opinions of the campaigns message evolved. Throughout the discussion, participants were individually and collectively progressing through the innovation-decision process, specifically the knowledge, persuasion, and decision stages (Rogers, 1983). The new information about regulations, the summer dry season, and the increase in water use through outdoor irrigation provided detailed context; the participants were able to comprehend and imagine a more detailed local water system. Through this new understanding, participants were able to assess the way the innovation of water conservation aligned with their personal attitudes and values. Some participants may have decided to adopt water conservation behaviors going forward, though the goal of the discussion was to improve the campaign and not to lead the participants to a decision about their behavior. The focus group allowed participants to progress through the first three stages of the 
innovation-decision process-knowledge, persuasion, and decision-while discussing the water conservation campaign.

While progressing partially through the decision-innovation process, some participants recognized their own barriers to action. Several individuals in the focus group expressed that they felt unable to adopt specific behaviors or perceived their impacts to be insignificantly beneficial, which discouraged them from participating. If an individual believes their impact won't make a difference in the big picture, they will be less likely to have the motivation and desire to put in the effort, energy, and money required to participate (Ajzen, 1991). Increasing individuals' PBC and perceived impact would remove potential barriers to water conservation behaviors.

One individual completely lacked the ability to cease watering his lawn and allow it to go dormant, which is the method of participation most promoted and desired by CRWP. This individual lives in a neighborhood with an active HOA that has specific rules about the appearance of front lawns that requires him to keep it green and forbids him from posting signs for more than two months each year. This individual was also a city council member, making him an actor at the individual scale and an agent at the municipal scale. At the individual scale, he is unable to participate in the ideal way due to the power his HOA has over his home. At the municipal scale, he has power and agency to make municipal decisions that could conserve more water than he could as an individual. This juxtaposition of power at different scales shows the complex layers of political ecology in the Clackamas River area and the way these political ecologies can become a potential barrier to simple water conservation behaviors.

The innovation-decision process is outlined as a way that an individual might adopt an innovation at any one time. The confirmation stage, when individuals continue to seek information after making the decision to adopt a behavior, is crucial to the success of the CRPW's water conservation campaign. Because individuals are asked to conserve only during summer months, water users will need to decide whether or not to adopt or re-adopt water conservation behaviors each year. The CRWP asks individuals to conserve water by ceasing all outdoor irrigation, installing water efficient devices, or changing water use behaviors. Some of these innovations, which I term installed innovations, can be installed once and then used year-round (e.g. washing machine, dishwasher, showerheads). A "smart" or programmable outdoor irrigation system only needs to be installed once, but will need to be reprogrammed throughout the year to adjust for fluctuations in precipitation. For installed innovations, the bulk of the decision-making effort will be done only once before installation, and individuals will not 
need to go through the innovation-decision process each year. Behavioral innovations, or water conservation behaviors that are based on the individual's water use habits and actions, will likely be reevaluated each year. Some examples of behavioral innovations are consciously taking shorter showers, using car washes that recycle water instead of washing your own car in your driveway, and deciding to water your lawn less during the dry season. The seasonality of the need to conserve water shapes the innovation-decision process into a complex and iterative process.

\section{Increasing awareness through the creation of knowledge}

The focus group demonstrated the importance of awareness regarding conservation behaviors. Participants who were previously uninformed about environmental issues in the watershed shared that they were more concerned about water use after learning about vulnerabilities and consequences. Their perceptions of resource availability had shifted. Whether their behavior will reflect their newfound concern for water availability is outside the scope of this paper, but the observed increase in concern is evidence for the benefits of creating more awareness of a local water resource issue.

Increasing awareness of water resource issues is one way of manipulating demand for water to help water providers ensure that supply will meet demand. Water user's perspectives of the water supply and watershed conditions influences the reality they experience regarding water as a resource. A study by Brugger et al (2019) outlined the ways in which different realities based on each groups' experiences and ideas of grazing land created persistent ongoing conflicts surrounding grazing in Arizona. Similarly, water managers and water users see the Clackamas River in different ways because they experience and understand it differently. These experiences as well as relevant legislation, scientific evidence, and cultural and ethical values can be selectively perceived to support a version of reality. The water user sees the water supply as comfortably sufficient for the community: without fail, every time they turn on a faucet in their home water pours out. Water managers have more interaction with the watershed than the water user and are more informed scientifically, politically, and economically. Water managers know supply is not always reliable, and they manipulate the system to ensure drinking water is available to their customers. For a water user, the realization that water supply might not be as reliable as they originally believed is an uncomfortable experience akin to dissonance, and they may selectively interpret information in order to avoid their version of reality changing. These different values and perceptions create a disconnect between actual supply and perceived supply, which can 
create dissonance in an individual learning of the need for water conservation in the Clackamas River and act as a barrier to adoption of water conservation as an innovation.

A key topic from the focus group was the idea to create a new social norm around what was deemed the "summer drought" since summers are typically dry in contrast to precipitation during the rest of the year. The creation of a social norm can be perceived as a form of knowledge creation, and in this case study, we see the CRWP working alongside members of the public to improve their campaign to create knowledge of the ecology, hydrology, and community of the watershed. Establishing this water conservation campaign as a local social norm and part of the social identity and memory will take time, effort, and funding, but incorporating local knowledge is a strong first step. By working with the community to improve their campaign strategy with local knowledge, and by bringing awareness to issues in the watershed that affect water users, the CRWP and focus group participants are co-creating local environmental knowledge specific to their shared water resource. By using the term "summer drought," CRWP can co-create knowledge and awareness within the watershed of the local climate trends that affect water supply and demand.

CRWP intends to use their summer water conservation messaging campaign to create a social norm of summer water conservation. Over time, the goal is that these technologies and behaviors are not seen as an innovation but are seen as part of an annual socially normative behavior that is practiced by the community. If water conservation becomes a social norm, the three factors that influence an individual's intention according to TBP will positively shift and make water conservation behavior more likely: subjective norms would favor water conservation and attitudes would be less likely to be negative. Additionally, PBC would increase because individuals would have conserved water in the past and would understand that they are able to conserve water, which would also facilitate the Knowledge portion of the Diffusion of Innovations process. This is possible through local and individual co-creation of the social norm focused on the "summer drought" experienced in the watershed that affects water supply annually.

\section{Suggestions for campaign improvements}

The focus group participants agreed that there is no one solution to increasing water conservation behaviors during summer months due to differing values and attitudes, awareness, and interest amongst the general population of local water users. Participants shared suggestions for improving the campaign as well as other programs they imagined would be successful. Regarding the 
focus of messaging, the participants had conflicting requests and opinions. They expressed desire for campaign message that was more broadly focused than the endangered salmon species, since they did not think everyone in the community would be motivated by the fish-focused messaging. They also believed the fish-focused messaging would be effective if the regulatory reasoning behind it was explicitly explained. Before the focus group, CRWP was against discussion of these regulations with the general public, but was open to explaining them to the focus group participants because it was a small group in a controlled environment. Whether the CRWP board changes their stance on future public discussion of the regulations is unknown at this time but there may be a change in the campaign's message at a later date. Participants also recommended improvements to outreach methods and materials and supported the use of social media to share conservation tips through short videos, graphics, and up-to-date data of local water use and flow levels of the River.

\section{Conclusion}

The predicted effects of climate change show changes in water availability which will only amplify the power water itself has in shaping human relations of power. This drives a need for an understanding of the present power relations surrounding water as well as the ways water use behaviors can be influenced. Through participant observation and focus group discussion interpreted through the lenses of political ecology and behavior theory, this study found potential methods of manipulating water supply and demand through water provider collaboration and water conservation messaging campaigns.

The promotion of water conservation efforts on the individual scale are a common method of addressing short supply, and CRWP are promoting a messaging campaign aiming to change the water use behaviors during a critical time of the year. To increase the effectiveness of this campaign, CRWP can make efforts to reduce barriers to water conservation behaviors, increase feelings of personal efficacy, and increase awareness of the issues within the watershed that drive the need for water conservation. Through the TBP and innovation-decision process we can understand how water users process information about water conservation practices and determine what influences their decision to adopt new behaviors or reject them.

This case study shows us how agents and actors at different scales within a watershed can affect and be affected by water supply. The finding of strong collaboration amongst local water providers to ensure adequate supply during times of drought and to prepare for potential trend shifts due to climate 
change shows us that natural resource managers are making the effort to get ahead of climate change. This research is intended to inform the CRWP's water conservation messaging campaign in future years but the results can be applied to a broader context. Water managers and other natural resource managers can learn from the lessons in collaboration and community engagement. 


\section{Bibliography}

About Us. (2014, May 14). Regional Water Providers Consortium. https://www.regionalh2o.org/aboutus

Ajzen, I. (1991). The theory of planned behavior. Organizational Behavior and Human Decision Processes, 50(2), 179-211. https://doi.org/10.1016/0749-5978(91)90020-T

Anderson, M. B., Ward, L., McEvoy, J., Gilbertz, S. J., \& Hall, D. M. (2016). Developing the water commons? The (post)political condition and the politics of "shared giving" in Montana. Geoforum, 74, 147-157. https://doi.org/10.1016/j.geoforum.2016.06.002

Brugger, J., McClaran, M. P., \& Sprinkle, J. (2019). 'Storytelling' Natural Resource Conflict on U.S. Public Lands: Ethnos: Vol 0, No 0. Ethnos - Journal of Anthropology.

https://doi.org/10.1080/00141844.2018.1456476

Chan, L., \& Bishop, B. (2013). A moral basis for recycling: Extending the theory of planned behaviour. Journal of Environmental Psychology, 36, 96-102. https://doi.org/10.1016/j.jenvp.2013.07.010

Chen, J., \& Chang, H. (2019a). Climate and Land Use Change Impacts on Water Quality and QuantityClackamas Watershed Resilience Project (Poster). Portland State University, Department of Geography. https://drive.google.com/file/d/1uQszJvFfON1S5Ct9wN2lalq-20okPN9Q/view?usp=embed_facebook

Chen, J., \& Chang, H. (2019b). Projected Changes in river discharge and sediment load in Clackamas River Watershed. Portland State University, Department of Geography. https://drive.google.com/file/d/1cV4Jho1XnepwynErHf935eYrlOxqKBI8/view?usp=embed_facebook Clackamas Fish Runs-Fish Counts \& Fish Runs | PGE. (n.d.). Retrieved November 23, 2019, from https://www.portlandgeneral.com/corporate-responsibility/environmental-stewardship/water-qualityhabitat-protection/fish-counts-fish-runs/clackamas-fish-runs

Clackamas River Water Providers | About Us. (n.d.). Retrieved November 23, 2019, from https://www.clackamasproviders.org/about-us/

Clackamas River Water Providers | Fish On The Run. (2019, July 1).

https://www.clackamasproviders.org/water-conservation/fish-on-the-run/

Clackamas River Water Providers | Water Efficient Plant Guide. (n.d.). Retrieved November 26, 2019, from https://www.clackamasproviders.org/water-efficient-plant-guide/

Cohen, A., \& Bakker, K. (2014). The Eco-Scalar Fix: Rescaling Environmental Governance and the Politics of Ecological Boundaries in Alberta, Canada. Environment and Planning D: Society and Space, 32(1), 128146. https://doi.org/10.1068/d0813

Conner, M. (2001). Health Behaviors. In N. J. Smelser \& P. B. Baltes (Eds.), International Encyclopedia of the Social \& Behavioral Sciences (pp. 6506-6512). Pergamon. https://doi.org/10.1016/B0-08-0430767/03871-7 
Conservation. (2014, May 14). Regional Water Providers Consortium.

https://www.regionalh2o.org/water-conservation

Crate, S. A. (2011). A Political Ecology of "Water in Mind": Attributing Perceptions in the Era of Global Climate Change. Weather, Climate, and Society, 3(3), 148-164. https://doi.org/10.1175/WCAS-D-1005006.1

Crifasi, R. R. (2002). The Political Ecology of Water Use and Development. Water International, 27(4), 492-503. https://doi.org/10.1080/02508060208687037

de Loë, R. C., Murray, D., \& Simpson, H. C. (2015). Farmer perspectives on collaborative approaches to governance for water. Journal of Rural Studies, 42, 191-205.

https://doi.org/10.1016/j.jrurstud.2015.10.005

Druschke, C. G. (2013). Watershed as Common-Place: Communicating for Conservation at the Watershed Scale. Environmental Communication, 7(1), 80-96.

https://doi.org/10.1080/17524032.2012.749295

Festinger, L. (1962). Cognitive Dissonance. Scientific American, 207(4), 93-106. JSTOR.

Gerlak, A. K. (2008). Today's Pragmatic Water Policy: Restoration, Collaboration, and Adaptive Management Along U.S. Rivers. Society \& Natural Resources, 21(6), 538-545.

https://doi.org/10.1080/08941920801907514

Hassinger, E. (1959). Stages in the Adoption Process. Rural Sociology, 24(1), 52-53.

Holley, C., \& Sofronova, E. (2017). New Environmental Governance: Adaptation, Resilience and Law (SSRN Scholarly Paper ID 3158904). Social Science Research Network.

https://papers.ssrn.com/abstract=3158904

Larson, D. (2019). Attitudes, Behaviors, and Archetypes in the Clackamas River Basin: A Model for Water Customer Analysis and Outreach for Watershed Protection and Conservation [Dissertation]. Portland State University.

Liang, Y. (Jake), Henderson, L. K., \& Kee, K. F. (2018). Running Out of Water! Developing a Message Typology and Evaluating Message Effects on Attitude Toward Water Conservation. Environmental Communication, 12(4), 541-557. https://doi.org/10.1080/17524032.2017.1288648

Loftus, A. (2009). Rethinking Political Ecologies of Water. Third World Quarterly, 30(5), 953-968. https://doi.org/10.1080/01436590902959198

Masson-Delmotte, V., Zhai, P., Portner, H. O., Roberts, D., Skea, J., Shukla, P. R., Pirani, A., MoufoumaOkia, W., Pean, C., Pidcock, R., Connors, S., Matthews, J. B. R., Chen, Y., Zhou, X., Gomis, M. I., Lonnoy, E., Maycock, T., Tignor, M., \& Waterfield, T. (2018). Summary for Policymakers (Global Warming of 1.5 oC). IPCC. https://www.ipcc.ch/sr15/chapter/spm/ 
Miller, E., \& Buys, L. (2008). The Impact of Social Capital on Residential Water-Affecting Behaviors in a Drought-Prone Australian Community. Society \& Natural Resources, 21(3), 244-257.

https://doi.org/10.1080/08941920701818258

Nielsen-Pincus, M., Chang, H., Holz, A., Loikith, P., Talke, S., Upton, E., Aragon, C., Chen, J., Rappaport, J., Gilden, B., Swan, K., \& Glazewski, M. (2018). Clackamas Watershed Resilience-Phase I Report. Institute for Sustainable Solutions, Portland State University. https://www.clackamasproviders.org/wpcontent/uploads/2019/01/CWR_Phase_1_Report.pdf

Oden, R., Nielsen-Pincus, M., Swan, K., \& Hollenbeck, C. (2019, October 8). Summer Water Conservation Campaign Focus Group [Personal communication].

OR DWR. (2018). Water Rights in Oregon: An Introduction to Oregon's Water Laws. Oregon Water Resources Department.

Perramond, E. P. (2005). The Politics of Ecology: Local Knowledge and Wild Chili Collection in Sonora, Mexico. Journal of Latin American Geography, 4(1), 59-75. https://doi.org/10.1353/lag.2005.0025

Petty, R. E., Haugtvedt, C. P., \& Smith, S. M. (1995). Elaboration as a determinant of attitude strength: Creating attitudes that are persistent, resistant, and predictive of behavior. In Attitude strength: Antecedents and consequences (pp. 93-130). Lawrence Erlbaum Associates, Inc.

Regional Coordination. (2014, May 14). Regional Water Providers Consortium. https://www.regionalh2o.org/regional-coordination

Regional Water Providers Consortium. (2019, November 5). Regional Consortium Conservation Committee. Regional Consortium Conservation Committee, Gresham City Hall.

Robbins, P. (2004). Political Ecology: A Critical Introduction. Wiley.

Rogers, E. M. (1983). Diffusion of Innovations. Free Press.

Sengupta, R., Lant, C., Kraft, S., Beaulieu, J., Peterson, W., \& Loftus, T. (2005). Modeling enrollment in the Conservation Reserve Program by using agents within spatial decision support systems: An example from southern Illinois. Environment and Planning B-Planning \& Design, 32(6), 821-834.

https://doi.org/10.1068/b31193

State of Oregon: Water Quality-Water Quality Standards. (n.d.). Retrieved October 30, 2020, from https://www.oregon.gov/deq/wq/Pages/WQ-Standards.aspx

Steg, L., \& Vlek, C. (2009). Encouraging pro-environmental behaviour: An integrative review and research agenda. Journal of Environmental Psychology, 29(3), 309-317.

https://doi.org/10.1016/j.jenvp.2008.10.004

Swan, K. (2019, December 2). Some background/regulation questions-Roden@pdx.edu-Portland State University Mail. https://mail.google.com/mail/u/0/\#inbox/FFNDWLJCVrdpPrtDJqmNgmhJzMZWFIrT 
Swyngedouw, E. (2009). The Political Economy and Political Ecology of the Hydro-Social Cycle. Journal of Contemporary Water Research \& Education, 142(1), 56-60. https://doi.org/10.1111/j.1936-

\section{X.2009.00054.x}

Thompson, S. C., \& Stoutemyer, K. (1991). Water Use as a Commons Dilemma: The Effects of Education that Focuses on Long-Term Consequences and Individual Action. Environment and Behavior, 23(3), 314333. https://doi.org/10.1177/0013916591233004

Warner, L. A., Lamm, A. J., Rumble, J. N., Martin, E. T., \& Cantrell, R. (2016). Classifying Residents who use Landscape Irrigation: Implications for Encouraging Water Conservation Behavior. Environmental Management, 58(2), 238-253. https://doi.org/10.1007/s00267-016-0706-2

Water Efficiency | The City of Portland, Oregon. (n.d.). Retrieved November 25, 2019, from https://www.portlandoregon.gov/water/29334

Watson, N., Shrubsole, D., \& Mitchell, B. (2019). Governance Arrangements for Integrated Water Resources Management in Ontario, Canada, and Oregon, USA: Evolution and Lessons. Water, 11(4), 663. https://doi.org/10.3390/w11040663

Zhong, F., Li, L., Guo, A., Song, X., Cheng, Q., Zhang, Y., \& Ding, X. (2019). Quantifying the Influence Path of Water Conservation Awareness on Water-Saving Irrigation Behavior Based on the Theory of Planned Behavior and Structural Equation Modeling: A Case Study from Northwest China. Sustainability, 11(18), 4967. https://doi.org/10.3390/su11184967 


\section{Chapter 2-}

\section{Environmental Concern and Local Water Conservation: How motivation acts as a mediator for political views}

\section{Introduction}

Water is an important resource used in agricultural food production, industrial production, and household uses for the individual. Though water is a renewable resource, local supply is also finite, which can lead to shortages during the drier seasons. Climate change is predicted to affect water supply by disrupting historical climate trends in uncertain ways (US Global Change Research Program, 2017). Water managers are preparing for these historical supply patters to change in various ways. One approach is to reduce the demand for water by promoting water conservation behaviors in urban areas.

Water conservation is often promoted through messaging campaigns that target changes in individual and household water use through various strategies. Because water is a natural resource, water conservation messaging campaigns often have an environmental component or connotation. Presently, environmental issues are a highly politicized issue in the United States, where politics have become extremely divisive. Because of this, water conservation is a political issue, which could affect the way people think and feel about adopting water conservation behaviors. In this study, we explore the relationship between water users' political views and their willingness to adopt water conservation behaviors. We use motivation-defined as the desire to perform an action-to conserve water as an indicator of environmental concern.

\section{Background}

\section{Water conservation messaging campaigns}

With the uncertainty surrounding future water supply, water managers are turning to water demand management, defined as the development and implementation of strategies aimed at influencing demand, so as to achieve efficient and sustainable use of a scarce resource (Brooks, 2006; Savenije \& Zaag, 2002). In order to reduce overall water use, it is crucial to focus on outdoor water conservation in urban areas as up to $70 \%$ of water use goes to maintaining landscape plantings like lawns (Hayden et al., 2015). Water providers often use social marketing techniques as part of their effort to affect demand. Social marketing uses commercial marketing techniques to promote an idea or behavior that benefits an individual or society (Monroe, 2003), and this can easily be applied to 
environmental messages like water conservation. Taking it one step further, water providers can use community based social marketing (CBSM), which is similar to social marketing with an increased emphasis on local action and stakeholder engagement in the process. The CBSM approach is comprised of five steps: 1 ) identifying barriers to behavior; 2) selecting optimal behaviors; 3 ) designing programs to overcome barriers to specific behavior; 4) piloting a behavior change program; and 5) evaluating program effectiveness (McKenzie-Mohr, 2000; Myers, 2016). In this case, the desired behavior change is a reduction in outdoor water use, specifically watering one's lawn in times of low supply.

Communicating and promoting desired behavior changes is often done through environmental messaging campaigns. Social influence and behavioral change campaigns are optimal approaches for water demand management as they are cost effective, easy to implement, and can result in significant water use reductions (Lede et al., 2019). Liang et al (2018) identified 12 major types of messages used in California during a severe prolonged drought and found that using one message type was less effective than using multiple messaging types. A common method to provoke behavior change is to provide information, and the public is commonly treated as if they have a "knowledge deficit" (Libutti \& Valente, 2006), though just providing information is often insufficient to move people to do the desired behavior (Shaw, 2010). Generally, even when individuals report concern for the environment, their attitude is not reflected in their actions (De Oliver, 1999; Miller \& Buys, 2008). Thus, water managers need to determine the ways in which their water users could become motivated enough to follow through with the suggested water conservation actions.

\section{Environmental concern and political views}

Environmental concern is an evaluation of or an attitudes towards facts, one's own behavior, or the behavior of others with consequences for the environment and may refer to a specific attitude that directly determines intentions, or more broadly to a general attitude or value orientation (Fransson \& Gärling, 1999). There five hypotheses predicting environmental concern based on different attributes of an individual: age, social class, residence (rural or urban), political views, and sex (Liere \& Dunlap, 1980). Studies show support for the Political Hypothesis, which states that Democrats and liberals are more concerned about environmental quality than are their Republican and conservative counterparts (Jones \& Dunlap, 1992; Liere \& Dunlap, 1980; Scott \& Willits, 2016). Though political views generally are a strong predictor of environmental attitudes, recent studies have demonstrated instances where another component overrode the standard political influence; for example, Nielsen-Pincus et al ( 2017) found 
that a strong sense of place offset conservative political values and resulted in higher environmental concern. Environmental concern and water conservation concern are strongly related to water conservation behaviors, though not all studies agree (Hannibal et al., 2019). This paper will investigate the effect of individuals' reported motivation as well as their political views on their likelihood of conserving water.

\section{The Theory of Planned Behavior}

The Theory of Planned Behavior (TPB) is used to explain all behaviors over which people have the ability to exert self-control (Ajzen, 1991). According to TBP, behaviors are a result of an individual's intentions. Intentions are determined by three components: attitudes, or the individual's overall evaluation of the behavior; subjective norms, or the individual's beliefs about whether other's think they should engage in the behavior; and the extent to which the individual perceives they have personal control over the behavior (Conner, 2001). TPB is often used in heath behavior studies but is easily transferrable to the context of pro-environmental behaviors and water conservation (Chan \& Bishop, 2013; Sengupta et al., 2005; Warner et al., 2016; Zhong et al., 2019).

The importance of intentions and its components emerge when TBP is applied to proenvironmental behaviors and water conservation. Though the intention to engage in pro-environmental behaviors may exist, these behaviors are not always realized. Though people feel responsible for water conservation, their behaviors and water use does not reflect this value manifesting as a practiced behavior (Miller \& Buys, 2008). Personal behavioral control (PBC) is an important component of this theory due to the nature of water conservation being a large problem that no single individual can fix. Individuals need to feel that the efforts they make are helping, thus when personal efficacy is perceived as low, people don't feel like their individual actions contribute enough (Thompson \& Stoutemyer, 1991) and they may disengage from conservation behaviors. In general, regardless of how much an individual values the environment, research shows that people are inconsistent in their environmental behaviors (Steg \& Vlek, 2009).

\section{Mediation Analysis}

Mediation analysis is a family of methods designed to determine information about the causal mechanism(s) by which a predictor affects an outcome (Preacher, 2015). Mediating variables are behavioral, biological, psychological, or social constructs that transmit the effect of one variable to 
another variable, and mediation is one way that a researcher can explain the process or mechanism by which one variable affects another (MacKinnon et al., 2007).

\section{Research Questions and Hypotheses}

This research seeks to understand the perceptions of a water conservation campaign as well as water users' attitudes and behaviors surrounding water conservation in general. We are seeking to answer the research questions:

Does an individual's motivation to conserve water predict their likelihood of actually conserving water through various behaviors?

How does motivation mediate the effect of an individual's political views on their perceived likelihood of acting to adopt water conservation behaviors?

The first research question is important to understand because water conservation messaging campaigns aim to motivate behavior changes in individuals to conserve water. In this study, we consider motivation to be an indicator of environmental concern. Motivation can be understood as the desire to perform an action, like conserving water. After participants were shown campaign information, motivation was measured by asking the participant to rate their level of motivation to reduce outdoor watering during the dry season. Understanding the ways in which motivation can predict the likelihood of conserving water can help us increase water conservation through influencing behavior change as understood by the Theory of Planned Behavior. We assume here that people with higher levels of environmental concern will have a stronger desire to reduce the negative consequences of their actions, and thus will have a higher motivation to conserve water during the dry season.

The second research question is important to evaluate because motivation - while influenced by political views - may have a separate effect on an individual's perceived likelihood of acting. There have been many studies on the correlation between political views and environmental concern, but we hypothesize that an individual's motivation may have a mediating effect on this relationship. Understanding this can help water providers adjust their campaign to their population and maximize water conservation in times of need. 


\section{Hypotheses}
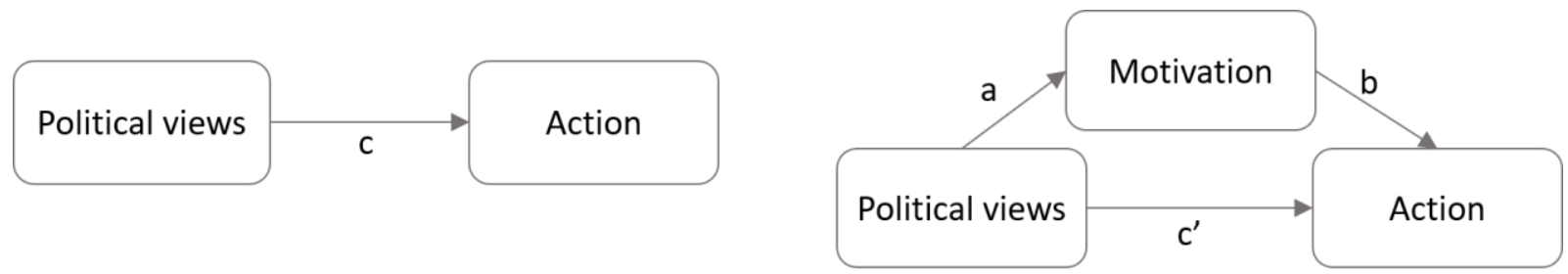

Figure 4. The figure on the left represents the relationship between political views and action without any mediation. The figure on the right is a single-mediator model with motivation as the mediator.

We expect to motivation to act as a mediator between an individual's political views and their

perceived likelihood of action. By definition, a mediator is a variable that is in a causal sequence between two other variables (MacKinnon et al., 2007) and we expect to see this relationship between political views, motivation, and perceived likelihood of acting to perform water conservation behaviors. As the political views of individuals are known to influence their interest in environmental campaigns, we can expect that political views will affect an individual's motivation, which will thus influence their likelihood of acting, meaning motivation is in a causal sequence between the independent variable political views and the dependent variable action. This is different from previous research because we are measuring and analyzing more than just an individual's political views, and we expect that these additional variables-motivation specifically-are important predictors of environmental concern and water conservation actions.

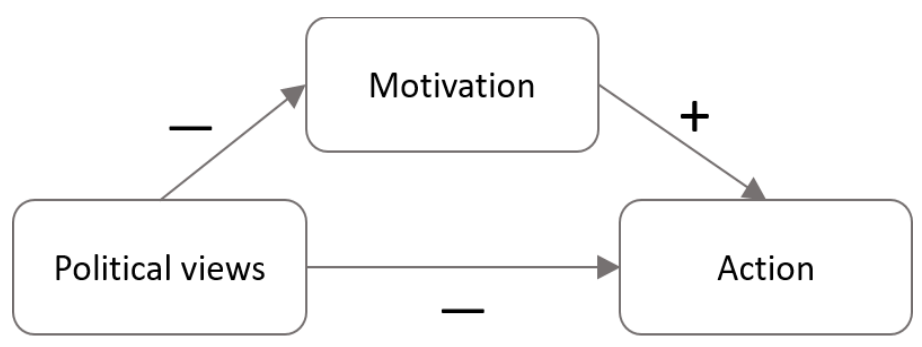

Figure 5. This figure shows the hypothesized relationships between political views, motivation, and action.

We expect to find a negative relationship between political views and motivation as well as political views and action, because political views were measured between -2 and 2 , with politically leftleaning views assigned to the negative values. Historically, people who identify themselves as being on the left side of the political spectrum are more likely to support environmental programs, so we predict individuals on the political left will have ranked their motivation and perceived likelihood of action higher. 


\section{Methods}

\section{Study Context}

The Clackamas River is a drinking water source for over 300,000 people located within the Portland metropolitan region in Oregon. Water managers must balance human and environmental water needs which can be challenging due to a lack of storage on the river, a seasonal dry period in the late summer and early fall, and increased water use during the dry season. The Clackamas River is supplied by snowpack throughout much of the year as well as ground water and surface runoff from precipitation. Typically, there is little to no precipitation in the late summer and early fall months, and by this time snowpack has been exhausted, resulting in low flows within the river. Due to the lack of precipitation, urban water users choose to water their lawns, which results in water use doubling and sometimes even tripling during the season when flows within the river are lowest. Additionally, endangered Coho and Fall Chinook salmon species are migrating upriver to spawn during late August, September and October. Minimum flow targets have been put into place to protect the spawning salmon during this time. Though these minimum flow targets have yet to be enforced, future changes to conditions mean it will be crucial to balance supply and demand.

Water managers anticipate that climate change will extend and intensify the summer dry season, and will cause more precipitation to fall as rain instead of snow thereby decreasing the natural reservoir of drinking water stored in snow and slowly released during the year. To prepare for a future with longer drier summers, water managers are focusing their attention on changing the demand of urban water users specifically during the crucial period when supply is low and demand is high. During the last two summers, water providers in the Clackamas watershed have promoted a specific and local water conservation message asking water users to reduce or curtail their outdoor water use during the dry season in order to leave water in the river for the spawning salmon. This water conservation campaign is an example of CBSM and follows all five steps. This study was conducted to evaluate public perception of this water conservation messaging campaign and to better understand general water conservation behaviors and attitudes across the watershed.

\section{Focus Group}

The first step of data collection for this research project was to conduct a focus group to create an opportunity to discuss the messaging campaign with engaged community members, as well as inform the design of the survey that would later be sent out to water users across the watershed. It was 
thought that the complex water issues in the watershed would be most effectively explained in person where the community members would have the opportunity to ask questions. Discussion during the focus group was centered around the participants awareness of local issues, perception of the campaign, motivation for action, and barriers to action. Over the course of the two-and-a-half-hour focus group, participants, water managers, and researchers were able to have an in-depth conversation about water issues in the Clackamas River watershed that contribute to the need for water conservation. As the participants' understanding of the issues changed, so did their attitudes towards the campaign. Findings from the focus group-especially the observed shift in understanding and attitudes-were used to develop the survey questions.

\section{Survey Instrument}

An online survey was emailed to water users and was posted on water providers' social media pages. The survey had four sections that focused on awareness of issues in the watershed, water conservation behaviors and attitudes, the water conservation campaign and the participants' perceptions of it, and the demographics of the participants. Political ideology was measured on a 5point scale from "far left" to "far right," numerically valued between -2 to 2, with a mid-point of "neither left nor right" at 0. Participants were asked "Based on the campaign messaging, how motivated are you to restrict or stop your outdoor water use during the dry season?" Their motivation was measured on a 5-point scale ranging from "not at all motivated" at 0 to "extremely motivated" at 4 . Perceived likelihood of action was created from a list of 8 different water conservation actions (see Table \#). Participants selected how likely they were to do each action within the next year from six options ranging between "definitely yes" (4) to "definitely no" (0) with an additional option of "not applicable to me." Additionally, the survey collected demographics including age (by selecting year of birth, annual household income (9 bins with a maximum of $\$ 200,000$ ), home ownership vs. renting, education, home type, gender, HOA membership, and number of years lived in Clackamas County.

\section{Study Sample}

This survey was distributed via email and social media. It was emailed to water customers who had participated in a local rebate program and chosen to share their contact information. To reach other water users who had not participated in this rebate program, a separate but identical survey was created and shared on the social media pages of water providers within the study area. As this survey was primarily sent to homeowners who have shown to already be engaged with their water providers 
through the rebate program, the study sample is not representative of all water users in the watershed. It is however, representative of the target audience of the water conservation campaign as the main ask of the campaign is to reduce or curtail outdoor water use, which is something homeowners are more likely to have the ability to do than those who rent or live in an apartment.

\section{Analysis}

As the primary objective of the water conservation campaign is to create behavior change in water users, the dependent variable used for this analysis was the participants' self-reported perceived likelihood of completing water conservation actions. These actions were measured through the participants' responses to a list of eight different actions: sign a watering campaign pledge card, putting a watering campaign sign in their yard, reducing how much they water their lawn and garden, letting their lawn go dormant, requesting a free landscape water audit, installing a water-saving outdoor watering system, installing indoor water-saving appliances, and seeking out rebate program information for water-saving devices.

The other variables used within this analysis are the participants' self-reported political views and their motivation to take water conservation actions after seeing the campaign materials. Political views were reported as part of the demographics section on a five-point scale. Motivation was reported directly after participants were shown information and materials from the water conservation campaign, and the question asking about motivation targeted the participants' motivation specific to conserving water by reducing or altogether stopping their outdoor watering during the dry period.

To reduce the number of dependent variables, we conducted a factor analysis and generated five versions of the action responses as variables. Next, we conducted a mediation analysis in $\mathrm{R}$ through the causal steps method for single-mediator models as outlined by Baron and Kenny (1986):

1. Show that the causal variable is correlated with the outcome. Estimate and test Path c; test X as a predictor of $\mathrm{Y}$ with a regression equation.

2. Show that the causal variable is correlated with the mediator. Estimate and test Path a, test $X$ as a predictor of $\mathrm{M}$ with a regression equation.

3. Show that the mediator affects the outcome variable. Estimate and test Path $b$; test $X$ and $M$ as predictors of $\mathrm{Y}$ with a regression equation. Control for $\mathrm{X}$ to establish the effect of $\mathrm{M}$ on $\mathrm{Y}$.

4. Estimate and test Path $c^{\prime}$; test the effect of $Y$ on $X$ controlling for $M$. Evaluate whether there is complete or partial moderation. If $c^{\prime}$ is zero, then $\mathrm{M}$ completely mediates the $\mathrm{X}-\mathrm{Y}$ relationship. 
These four steps were completed with linear regressions in order to find and estimate paths a, b, $c$, and $c^{\prime}$. Mediation can be determined if the absolute value of the coefficient of path $c$ is greater than the coefficient for path c' (MacKinnon et al., 2007). Then, the data was run through the mediation package in R (Tingley et al., 2014), giving the Average Causal Mediation Effects (ACME), the Average Direct Effects ( $A D E)$, the Total Effect, and the Proportion Mediated. To determine whether mediation occurs, we evaluated the results based on the estimates and significance of ACME and the comparison of $c$ and c'. Because confidence limits are important for understanding effects, we followed Mackinnon et al.'s (2007) recommendation to use bootstrapped confidence intervals.

\section{Results}

For the emailed survey, 626 emails were sent, 320 people participated, and 288 people completed the survey fully (completion rate of $46 \%$, participation rate of $51 \%$ ). An additional 122 people participated in the social media survey with 95 surveys fully completed and 26 partially completed. These populations were evaluated for any significant differences and none were found, so the data were combined into one sample of Clackamas water users. The sample population had a homeownership rate of $95 \%$, a median household income of $\$ 112,499$, and the median age was 56 . All of these values are higher than the same measurements from the most recent census, demonstrating that the sample population is older, wealthier, and much more likely to be a home owner than the overall population.

Just over half of participants rated themselves as feeling "somewhat" motivated by the campaign, with less than a quarter of participants reporting themselves as "extremely" or "very" motivated, and a quarter of participants rating themselves as "not very" or "not at all" motivated. Politically, just under half of the sample population considered themselves to be "extremely left" or "left," with a quarter marking themselves as "neither left nor right," and just under a third marking themselves as "right."

\section{Factor Analysis}

To reduce the number of dependent variables, we conducted a factor analysis in $\mathrm{R}$ using maximum likelihood estimation methods and used the results to generate new dependent variables. We used the criteria of loadings greater than 0.4 , and selected three factors that explained $57 \%$ of variance. We used Chronbach's alpha to check the reliability of the grouped responses which both met the criteria of $\alpha>0.7$ 
Table 4. Results from the factor analysis. Three factors were selected, creating groups of four actions and two actions, with "reduce" left in its own group. To enable evaluation of all action items, a fourth factor of "dormant" responses was also analyzed.

\begin{tabular}{|l|r|r|r|r|r|}
\cline { 5 - 7 } \multicolumn{2}{l}{} & \multicolumn{3}{c|}{ Varimax rotated factor } \\
\hline loadings
\end{tabular}

We created five dependent variables by averaging the responses to all eight action questions for "Average," the responses to the grouped questions according to the factor analysis results for "Install" and "Campaign," and by using the raw responses to the "Dormant" and "Reduce" questions. These five dependent variables were used to perform a mediation analysis.

\section{Mediation Analysis}

The mediation analyses for all five dependent variables-Average, Install, Campaign, Dormant, and Reduce-yielded significant values for ACME with a difference between coefficients for paths $\mathrm{c}$ and $c^{\prime}$ that indicates significant mediation is occurring. An individual's motivation mediates the relationship between their political views and their perceived likelihood of acting to conserve water. We saw high correlation for Average, Campaign, and Reduce, with $\mathrm{R}^{2}$ values of $0.38,0.39$, and 0.34 respectively. See Table 2 for full results. 
Motivation Responses

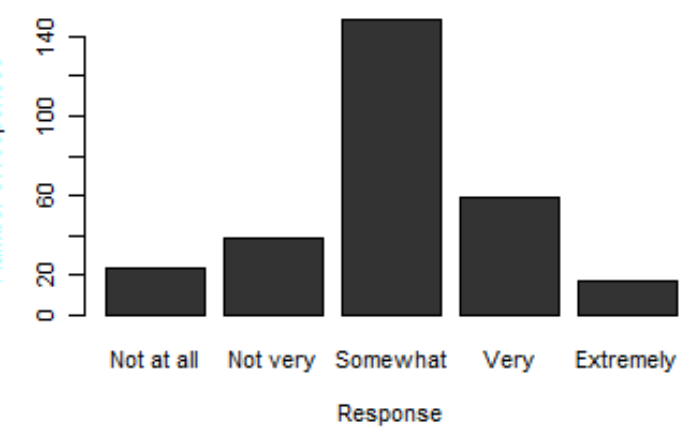

Install

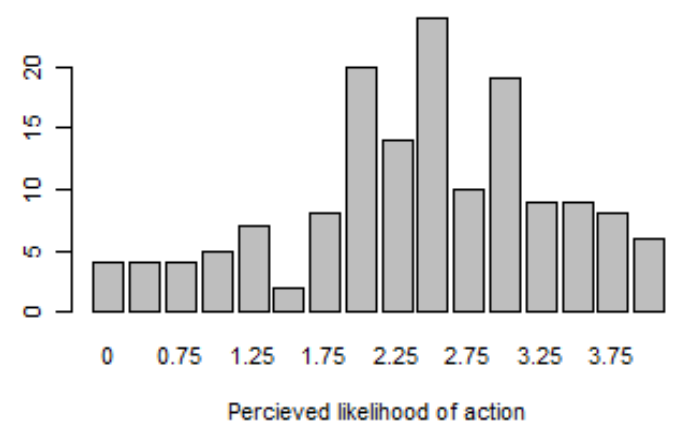

Dormant

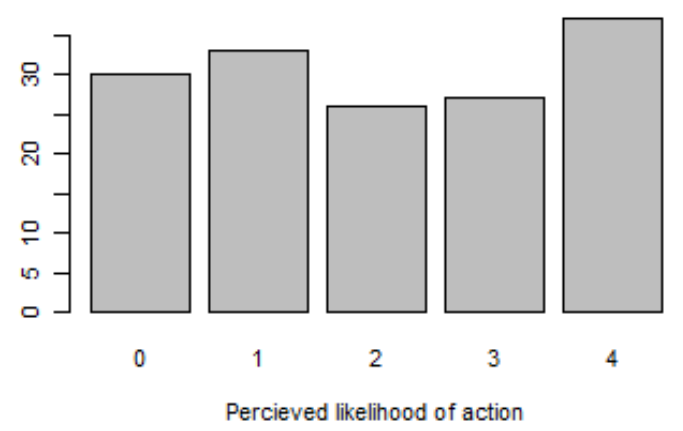

Political Views Responses

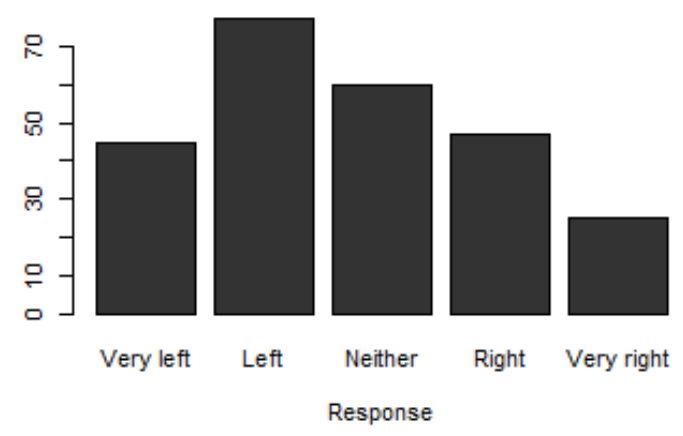

Campaign

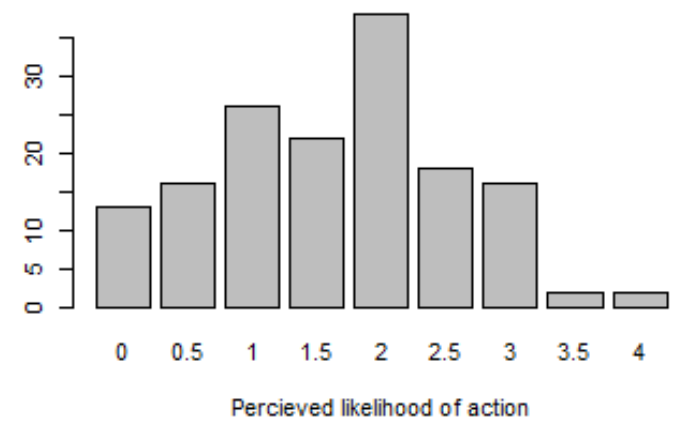

Reduce

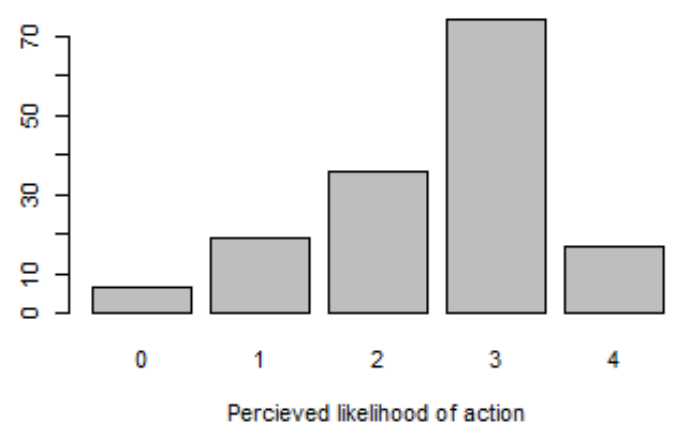

Figure 6. These histograms display the responses from survey participants regarding specific questions. The first two (shaded in black) are used as predictor variables within the mediation analysis. The bottom four are response variables. "Install" responses are an average of four responses ("install a water-saving outdoor watering system," "seek out rebate program information for water-saving devices," "request a free landscaping audit," and "install indoor water-saving appliances"). "Campaign" is an average of two responses ("sign a watering campaign pledge card" and "put a watering campaign sign in your yard"). 
Table 5. Coefficients for the single-mediator models for all five dependent variables. Significance codes: *** $p<0.001, * * p<0.01, * p<0.05$. +Confidence intervals for ACME were evaluated through bootstrapping.

\begin{tabular}{|c|c|c|c|c|c|}
\hline & \multicolumn{5}{|c|}{ Dependent Variable } \\
\hline & Average & Install & Campaign & Dormant & Reduce \\
\hline $\begin{array}{l}\text { Path a (Political } \rightarrow \\
\text { Motivation) }\end{array}$ & $-0.218 * * *$ & $-0.218 * * *$ & $-0.218 * * *$ & $-0.218 * * *$ & $-0.218 * * *$ \\
\hline $\begin{array}{l}\text { Path b (Political }+ \\
\text { Motivation } \rightarrow \text { Action) }\end{array}$ & $0.479 * * *$ & $0.340 * * *$ & $0.625^{* * *}$ & $0.595^{* * *}$ & $0.626 * * *$ \\
\hline Path c (Political $\rightarrow$ Action) & $-0.154^{* *}$ & -0.109 & $-0.171^{* *}$ & $-0.271 * *$ & $-0.183 * *$ \\
\hline Adjusted R2 & 0.38 & 0.11 & 0.39 & 0.17 & 0.34 \\
\hline ADE (Path c') & -0.0482 & -0.0349 & -0.0326 & -0.137 & -0.0468 \\
\hline Total Effect & $-0.1531 * *$ & -0.1097 & $-0.168 * *$ & $-0.268 * *$ & $-0.1833 *$ \\
\hline Proportion Mediated & $0.6881^{* *}$ & 0.6651 & $0.8021^{* *}$ & $0.485^{* *}$ & $0.7416^{*}$ \\
\hline ACME & $-0.1049 * * *$ & $-0.0748 * * *$ & $-0.1354 * * *$ & $-0.1310 * * *$ & $-0.1365 * * *$ \\
\hline $\begin{array}{l}\text { ACME confidence interval } \\
\text { lower }^{\dagger}\end{array}$ & -0.18 & -0.1419 & -0.2169 & -0.246 & -0.2317 \\
\hline $\begin{array}{l}\text { ACME confidence interval } \\
\text { upper }^{+}\end{array}$ & -0.05 & -0.02 & -0.06 & -0.05 & -0.06 \\
\hline
\end{tabular}

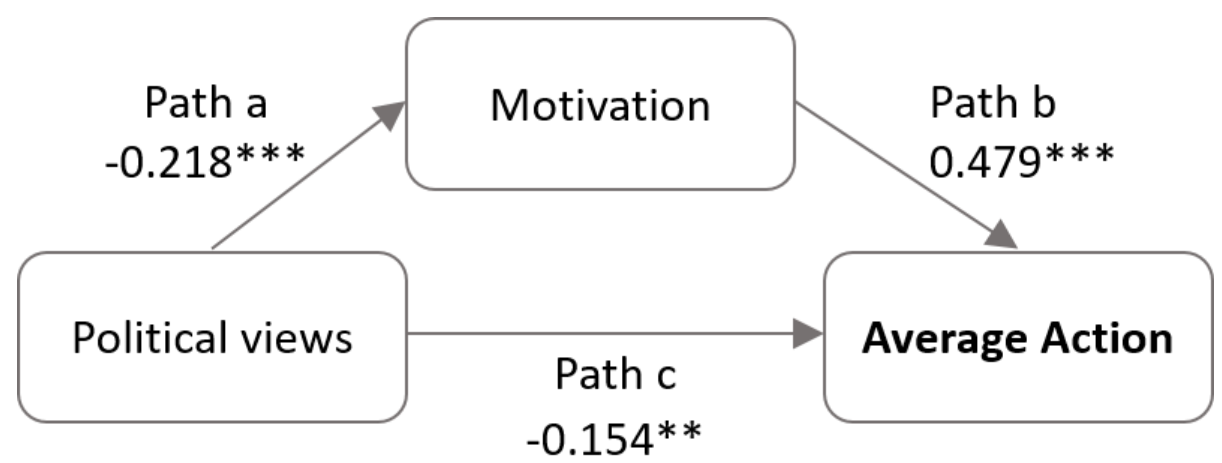

Figure 7. This model shows the significance and coefficient values for the three different paths calculated during the mediation analysis for the Average dependent variable.

\section{Hypothesis Results}

The relationships between the variables were as we hypothesized: the relationships between political views and motivation as well as political views and action were both negative, with the relationship between motivation and action being positive. 


\section{Discussion}

From our results, we see that motivation acts as a mediator between an individual's political values and their perceived likelihood of acting to conserve water. This relationship is true for all of our dependent variables and their corresponding actions. This aligns with the TBP because it shows that multiple values and attitudes contribute to an individual's actions (Ajzen, 1991). Our finding somewhat contradicts the study conducted by Addo et al (2018) that determined through a multiple-moderation model analysis that motivation is moderately related to water use behavior.

Our results contradict previous thinking about the factors that influence individual's environmental concern, specifically political views being a key predictor. Since motivation acts as a mediator, it's clear that an individual's environmental concern is influenced by more than just their political views. Motivation to participate in this water conservation campaign was correlated with an individual's political views, but there are other components influencing motivation that were not measured. Future studies should evaluate the components of motivation as well as other factors that influence an individual's environmental concern and participation in pro-environmental behaviors.

Three of the tested dependent variables had higher correlations with motivation and political views: Average, Campaign, and Reduce. Overall, based on the average of the responses to the eight water conservation behaviors, we see that political views and motivation are correlated with an individual's self-reported likelihood of acting to conserve water. This average value is helpful because it removes some of the difference we see between different actions and allows us to understand the individual's general likelihood of conserving water in the near future.

We also saw a strong correlation with the two campaign behaviors that made up the Campaign dependent variable. These two actions-signing a campaign pledge card and displaying a campaign sign in their yard-were the lowest risk and lowest effort actions. These actions are cost no money to do and have few steps to complete. There was also a low risk with these actions, as signing the pledge card had no consequences if the individual did or didn't follow through with water conservation behaviors, and the yard sign can be easily placed and removed if they reverse their decision to display it.

The strong correlation with outdoor watering reduction is a good sign for CRWP and this campaign, as one of the two main asks of the campaign were to reduce outdoor watering or let your 
lawn go dormant. If water conservation campaigns can increase the number of people who feel motivated, they may see water conservation behaviors increase as well.

We found weaker correlations with the action of letting one's lawn go dormant for the dry season. Responses to this question had the most uniform distribution (see Figure 3). Though this action requires the least amount of effort (since it is more of a shift from the action of watering one's lawn to the inaction of not watering one's lawn) it can be seen as the riskiest. In many neighborhoods, a dry brown lawn that has been left to go dormant will draw attention and comments from neighbors. Additionally, a well-kept green lawn is viewed as a status symbol (Robbins, 2012; Weigert, 1994), and homeowners may perceive letting their lawn go dormant as a reduction in their status and home value. Because of these risks, individuals were less likely to let their lawn go dormant and more likely to state high changes of reducing their outdoor watering. This is an opportunity for messaging campaigns, and studies show that efforts to enhance community awareness, provide info about landscape options and alternatives, and demonstrate how water use is affected by landscape choices can lead to increased adoption of more water conserving landscapes (Hurd, 2006).

The other weaker correlation was seen in relation to the Install dependent variable, which was the average of four actions: installing indoor water-saving devices, installing outdoor water-saving devices, seeking out rebate information, and signing up for a free outdoor water use audit. As the respondents of this survey had already participated in CRWP's rebate plan, we could be seeing a weaker correlation due to the fact that these water users have already installed water-saving devices and either don't have any additional devices to upgrade or are not interested in the costs to install any more. These installations represent one-and-done water conservation actions, meaning the mental work of decisionmaking and acting occurs up front when purchasing and installing the device, as opposed to behavior changes that require habit adjustments and consistent motivation to change the behavior.

There was also high interest in rebate programs for water-saving devices, as they reduce the financial cost of installing these devices for the water user. Though there may be financial costs to water providers, offering rebates for both indoor and outdoor water-saving devices is an effective strategy. Upgrading appliances is not tied to environmental concern but to household economic situation, even more than water scarcity (Hannibal et al., 2019). This can be seen in Australia, where the government offered rebates for water-saving devices, and more than $2 / 3$ of study sample had installed these devices, many because of the rebates and incentives (Allon \& Sofoulis, 2006). Though installed devices 
may cost homeowners money, they offer a one-and-done solution to water conservation that can be seen as a lighter mental burden than that of regular behavior changes. This is not surprising as humans tend to choose the easier alternative of environmental actions for themselves (Attari et al., 2016). Whether spending money is easier than changing behavior is a decision made by the individual.

Though this study focused on one watershed in Oregon, the results have implications for water managers across the US. Water demand management is an effective strategy and water conservation messaging campaigns are a key component that water providers can take advantage of. Making use of multiple messaging strategies as outlined by Liang et al (2018) can greatly improve the success of a water conservation campaign. Communicating with water users in times of need is essential to defining acceptable behaviors, as communication can change behavior by challenging the view that wasting water is appropriate (Addo et al., 2018). If water providers frame the need for water conservation as a problem the community is facing, individuals who identify with the community who may feel a lack of efficacy as individuals may instead feel effective when they act as part of their community (Bandura, 1997).

Environmental campaigns like water conservation campaigns often aim to create or increase awareness about local problems in order to motivate behavior change. In the Clackamas River watershed, many water users are unaware about low river flow during the late summer and early fall because this problem is unique to the watershed. Focusing on the qualities of the watershed that make it unique can help generate the feeling of community that can motivate individuals to change their behaviors. However, studies show that individuals with a pre-existing belief about water availability may utilize this belief to reject contradicting evidence that they receive via messaging campaigns (Hurlimann \& Dolnicar, 2011) and that prior attitudes influence information processing and subsequent responses to persuasive messages (Hart et al., 2009). Water managers promoting water conservation campaigns should keep this in mind, and reflect on the potential pre-existing beliefs their water users may have about local water supply. Additionally, water managers should keep in mind that despite the recognition of water scarcity, the intention to conserve water does not always translate to individual behavior changes (De Oliver, 1999), and water conservation campaigns should not be relied upon as the only tool for water demand management.

Because this sample population is made up of individuals who have previously participated in CRWP's rebate population, we are evaluating a population that is already engaged with their water 
provider and water conservation behaviors, though those may be motivated by various things (money, environmental values, etc.). The sample population are also primarily homeowners, which is not the case with the general population. This is acceptable for CRWP though, because their water conservation campaign is primarily targeted towards homeowners with the aim of persuading them to cease or reduce watering their lawns. Additionally, through the survey we were only able to measure behavioral intent and not actual behaviors.

\section{Conclusion}

With the future of water supply growing increasingly uncertain due to climate change, water managers and water providers can use water demand management to help ensure supply can meet demand. A key component of water demand management is the use of water conservation messaging campaigns that inform the public of water issues and attempt to create behavior change. Water conservation messaging campaigns can be strategically executed in multiple ways, and it's more effective to use more than one strategy in order to reach multiple audiences within the target population of water users.

Previous studies tell us that political views are a key predictor of environmental concern and water conservation behaviors, but we found that motivation to conserve water acts as a mediator between political views and water conservation actions. This is important for water providers to know when they plan and promote water conservation campaigns to their water users. While this information is helpful, this study measured behavioral intentions and not actual behaviors. Future research should investigate motivation's effects on actual behaviors, as well as whether this mediated effect is different for different political groups. Additionally, researchers should seek to understand other factors that could influence the relationship between an individual's political views and their environmental concern and resulting behaviors, like place identity.

Though human behavior can be difficult to predict and change, increasing environmental concern through motivation to practice water conservation behaviors will help water managers ensure supply can meet demand in the face of uncertainty. 


\section{Bibliography}

Addo, I. B., Thoms, M. C., \& Parsons, M. (2018). Household Water Use and Conservation Behavior: A Meta-Analysis. Water Resources Research, 54(10), 8381-8400. https://doi.org/10.1029/2018WR023306 Ajzen, I. (1991). The theory of planned behavior. Organizational Behavior and Human Decision Processes, 50(2), 179-211. https://doi.org/10.1016/0749-5978(91)90020-T

Allon, F., \& Sofoulis, Z. (2006). Everyday Water: Cultures in transition. Australian Geographer, 37(1), 4555. https://doi.org/10.1080/00049180500511962

Attari, S. Z., Krantz, D. H., \& Weber, E. U. (2016). Energy conservation goals: What people adopt, what they recommend, and why. Judgment and Decision Making; Tallahassee, 11(4), 342-351.

Bandura, A. (1997). Self-Efficacy: The Exercise of Control. Macmillan.

Baron, R. M., \& Kenny, D. A. (1986). The moderator-mediator variable distinction in social psychological research: Conceptual, strategic, and statistical considerations. Journal of Personality and Social Psychology, 51(6), 1173-1182. https://doi.org/10.1037/0022-3514.51.6.1173

Brooks, D. B. (2006). An Operational Definition of Water Demand Management. International Journal of Water Resources Development, 22(4), 521-528. https://doi.org/10.1080/07900620600779699

Chan, L., \& Bishop, B. (2013). A moral basis for recycling: Extending the theory of planned behaviour. Journal of Environmental Psychology, 36, 96-102. https://doi.org/10.1016/j.jenvp.2013.07.010

Conner, M. (2001). Health Behaviors. In N. J. Smelser \& P. B. Baltes (Eds.), International Encyclopedia of the Social \& Behavioral Sciences (pp. 6506-6512). Pergamon. https://doi.org/10.1016/B0-08-0430767/03871-7

De Oliver, M. (1999). Attitudes and Inaction: A Case Study of the Manifest Demographics of Urban Water Conservation. Environment and Behavior, 31(3), 372-394.

https://doi.org/10.1177/00139169921972155

Fransson, N., \& Gärling, T. (1999). Environmental concern: Conceptual definitions, measurement methods, and research findings. Journal of Environmental Psychology, 19(4), 369-382.

https://doi.org/10.1006/jevp.1999.0141

Hannibal, B., Sansom, L., \& Portney, K. E. (2019). The effect of local water scarcity and drought on water conservation behaviors. Environmental Sociology, 5(3), 294-307.

https://doi.org/10.1080/23251042.2018.1519882

Hart, W., Albarracín, D., Eagly, A. H., Brechan, I., Lindberg, M. J., \& Merrill, L. (2009). Feeling validated versus being correct: A meta-analysis of selective exposure to information. Psychological Bulletin, 135(4), 555-588. https://doi.org/10.1037/a0015701 
Hayden, L., Cadenasso, M. L., Haver, D., \& Oki, L. R. (2015). Residential landscape aesthetics and water conservation best management practices: Homeowner perceptions and preferences. Landscape and Urban Planning, 144, 1-9. https://doi.org/10.1016/j.landurbplan.2015.08.003

Hurd, B. H. (2006). Water Conservation and Residential Landscapes: Household Preferences, Household Choices. Journal of Agricultural and Resource Economics. https://doi.org/10.22004/ag.econ.8605

Hurlimann, A., \& Dolnicar, S. (2011). Voluntary relocation - An exploration of Australian attitudes in the context of drought, recycled and desalinated water. Global Environmental Change, 21(3), 1084-1094. https://doi.org/10.1016/j.gloenvcha.2011.03.003

Jones, R. E., \& Dunlap, R. E. (1992). The Social Bases of Environmental Concern: Have They Changed Over Time? Rural Sociology, 57(1), 28-47. https://doi.org/10.1111/j.1549-0831.1992.tb00455.x

Lede, E., Meleady, R., \& Seger, C. R. (2019). Optimizing the influence of social norms interventions: Applying social identity insights to motivate residential water conservation. JOURNAL OF ENVIRONMENTAL PSYCHOLOGY, 62, 105-114. https://doi.org/10.1016/j.jenvp.2019.02.011

Liang, Y. (Jake), Henderson, L. K., \& Kee, K. F. (2018). Running Out of Water! Developing a Message Typology and Evaluating Message Effects on Attitude Toward Water Conservation. Environmental Communication, 12(4), 541-557. https://doi.org/10.1080/17524032.2017.1288648

Libutti, L., \& Valente, A. (2006). Science communication and information dissemination: The role of the information professional in the 'Perception and Awareness of Science' project. Journal of Information Science, 32(2), 191-197. https://doi.org/10.1177/0165551506062335

Liere, K. D. V., \& Dunlap, R. E. (1980). The Social Bases of Environmental Concern: A Review of Hypotheses, Explanations and Empirical Evidence. Public Opinion Quarterly, 44(2), 181-197. https://doi.org/10.1086/268583

MacKinnon, D. P., Fairchild, A. J., \& Fritz, M. S. (2007). Mediation Analysis. Annual Review of Psychology, 58(1), 593-614. https://doi.org/10.1146/annurev.psych.58.110405.085542

McKenzie-Mohr, D. (2000). New Ways to Promote Proenvironmental Behavior: Promoting Sustainable Behavior: An Introduction to Community-Based Social Marketing. Journal of Social Issues, 56(3), 543554. https://doi.org/10.1111/0022-4537.00183

Miller, E., \& Buys, L. (2008). The Impact of Social Capital on Residential Water-Affecting Behaviors in a Drought-Prone Australian Community. Society \& Natural Resources, 21(3), 244-257.

https://doi.org/10.1080/08941920701818258

Monroe, M. C. (2003). Two Avenues for Encouraging Conservation Behaviors. Human Ecology Review, 10(2), 113-125. 
Myers, N. (2016, July 1). Community-Based Social Marketing: Tools for reducing demand through behavior change. Environmental Finance Blog. http://efc.web.unc.edu/2016/07/01/community-basedsocial-marketing/

Nielsen-Pincus, M., Sussman, P., Bennett, D. E., Gosnell, H., \& Parker, R. (2017). The Influence of Place on the Willingness to Pay for Ecosystem Services. Society \& Natural Resources, 30(12), 1423-1441.

https://doi.org/10.1080/08941920.2017.1347976

Preacher, K. J. (2015). Advances in Mediation Analysis: A Survey and Synthesis of New Developments. Annual Review of Psychology, 66(1), 825-852. https://doi.org/10.1146/annurev-psych-010814-015258

Robbins, P. (2012). Lawn People: How Grasses, Weeds, and Chemicals Make Us Who We Are. Temple University Press.

Savenije, H. H. G., \& Zaag, P. van der. (2002). Water as an Economic Good and Demand Management Paradigms with Pitfalls. Water International, 27(1), 98-104.

https://doi.org/10.1080/02508060208686982

Scott, D., \& Willits, F. K. (2016). Environmental Attitudes and Behavior: A Pennsylvania Survey. Environment and Behavior. https://doi.org/10.1177/001391659402600206

Sengupta, R., Lant, C., Kraft, S., Beaulieu, J., Peterson, W., \& Loftus, T. (2005). Modeling enrollment in the Conservation Reserve Program by using agents within spatial decision support systems: An example from southern Illinois. Environment and Planning B-Planning \& Design, 32(6), 821-834.

https://doi.org/10.1068/b31193

Shaw, B. (2010). Integrating temporally oriented social science models and audience segmentation to influence environmental behaviors. In Communicating Science: New Agendas in Communication (pp. 109-130). Routledge.

Steg, L., \& Vlek, C. (2009). Encouraging pro-environmental behaviour: An integrative review and research agenda. Journal of Environmental Psychology, 29(3), 309-317.

https://doi.org/10.1016/j.jenvp.2008.10.004

Thompson, S. C., \& Stoutemyer, K. (1991). Water Use as a Commons Dilemma: The Effects of Education that Focuses on Long-Term Consequences and Individual Action. Environment and Behavior, 23(3), 314333. https://doi.org/10.1177/0013916591233004

Tingley, D., Yamamoto, T., Hirose, K., Keele, L., \& Imai, K. (2014). mediation: R Package for Causal Mediation Analysis. Journal of Statistical Software, 59(1), 1-38. https://doi.org/10.18637/jss.v059.i05 US Global Change Research Program. (2017). Climate Science Special Report: Fourth National Climate Assessment, Volume 1. 
Warner, L. A., Lamm, A. J., Rumble, J. N., Martin, E. T., \& Cantrell, R. (2016). Classifying Residents who use Landscape Irrigation: Implications for Encouraging Water Conservation Behavior. Environmental Management, 58(2), 238-253. https://doi.org/10.1007/s00267-016-0706-2

Weigert, A. J. (1994). Lawns of Weeds: Status in Opposition to Life. The American Sociologist, 25(1), 8096. JSTOR.

Zhong, F., Li, L., Guo, A., Song, X., Cheng, Q., Zhang, Y., \& Ding, X. (2019). Quantifying the Influence Path of Water Conservation Awareness on Water-Saving Irrigation Behavior Based on the Theory of Planned Behavior and Structural Equation Modeling: A Case Study from Northwest China. Sustainability, 11(18), 4967. https://doi.org/10.3390/su11184967 
This project, a collaborative effort between the water provider partnership known as the Clackamas River Water Providers and researchers at Portland State University, used focus group, participant observation, and survey research to understand individual water users' attitudes and beliefs about water conservation, and how an individual's political views and motivation to participate can influence their likelihood of completing water conservation behaviors. This research has important lessons for water providers and natural resource managers who are looking ahead to the potential trend shifts of water supply due to climate change.

\section{Findings}

Through participant observation and focus group research, we found agents at different scales within the water sector: state agents, local or municipal agents, and individual water users. Through their actions and decisions, the agents at each level can affect the power and actions of the agents at the other scales. We also found evidence of agents at the local scale-local water providerscollaborating with each other in order to avoid problems that would affect all of them later on, even if those problems only affected one or two water providers in the immediate future. Water providers seek to influence the behaviors of their water users through water conservation campaign messaging in order to reduce demand when supply is low. These individuals are responsive to water conservation messaging but do not always have the ability to conserve water as asked.

Through survey research, we found that an individual's political views influence how motivated they feel about participating in a water conservation campaign and how likely it is that they will participate. This is because environmental issues and climate change are framed in the US as political issues, and one party is generally more pro-environment than the other. We found that awareness matters, especially in a place where the historical climate is wet throughout most of the year like the Clackamas River basin. Additionally, empowerment matters; if an individual feels the costs of their efforts don't adequately aid the effort to conserve water, they are less likely to feel motivated or participate.

\section{Why this research matters}

Water providers across the US can make use of our findings to improve their efforts to promote water conservation and prepare for changes in water supply due to climate change. As this research 
found that the framings used in our survey were equally effective, water providers do not need to limit themselves to one particular message and can instead utilize multiple message framings in order to align with the values of their water users. Understanding the political views of their population can help them determine the best way to frame the problems leading to a need for water conservation as well as the desired behavior changes. This can increase motivation to conserve water across all audiences and political groups, and since motivation can overcome the influence of conservative political views, higher overall motivation will help increase water conservation behaviors and reduce demand during low supply periods.

\section{Recommendations for future research}

To better understand attitudes and beliefs about water conservation, we recommend future research focus on the ways water providers can create social norms in order to establish a culture of water conservation during dry seasons in addition to well-advertised drought periods. Additionally, exploring variables other than political views that may influence water users' attitudes towards water conservation would help water providers understand their customers better and could benefit other types of environmental campaigns. As we found evidence that political views are not the only influence of an individual's motivation and potential for following water conservation behaviors, we recommend conducting studies that identify and measure the traits that influence an individual's motivations to participate in an environmental effort.

Overall, this research project helps us understand that each individual water user has the opportunity to conserve water and be part of a community effort to benefit the environment and the population of water users as a whole. The effects of climate change are being felt already today and are likely to increase in intensity, so it is more important than ever that we work together to secure valuable natural resources like our water supply. 
Appendix: Executive Report

Clackamas River Water Providers Summer Watering Campaign Assessment: Results from a survey of water users, June 3, 2020 


\section{Clackamas River Water Providers}

\section{Summer Watering Campaign Assessment -}

\section{Results from a survey of water users}

\section{June 3, 2020}

Survey Report

Rikki Oden

Dr. Max Nielsen-Pincus

Department of Environmental Science and Management,

Portland State University

In Collaboration With

Clackamas River Water Providers

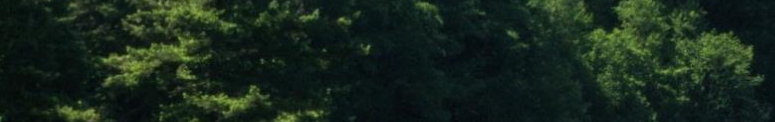




\section{Table of Contents}

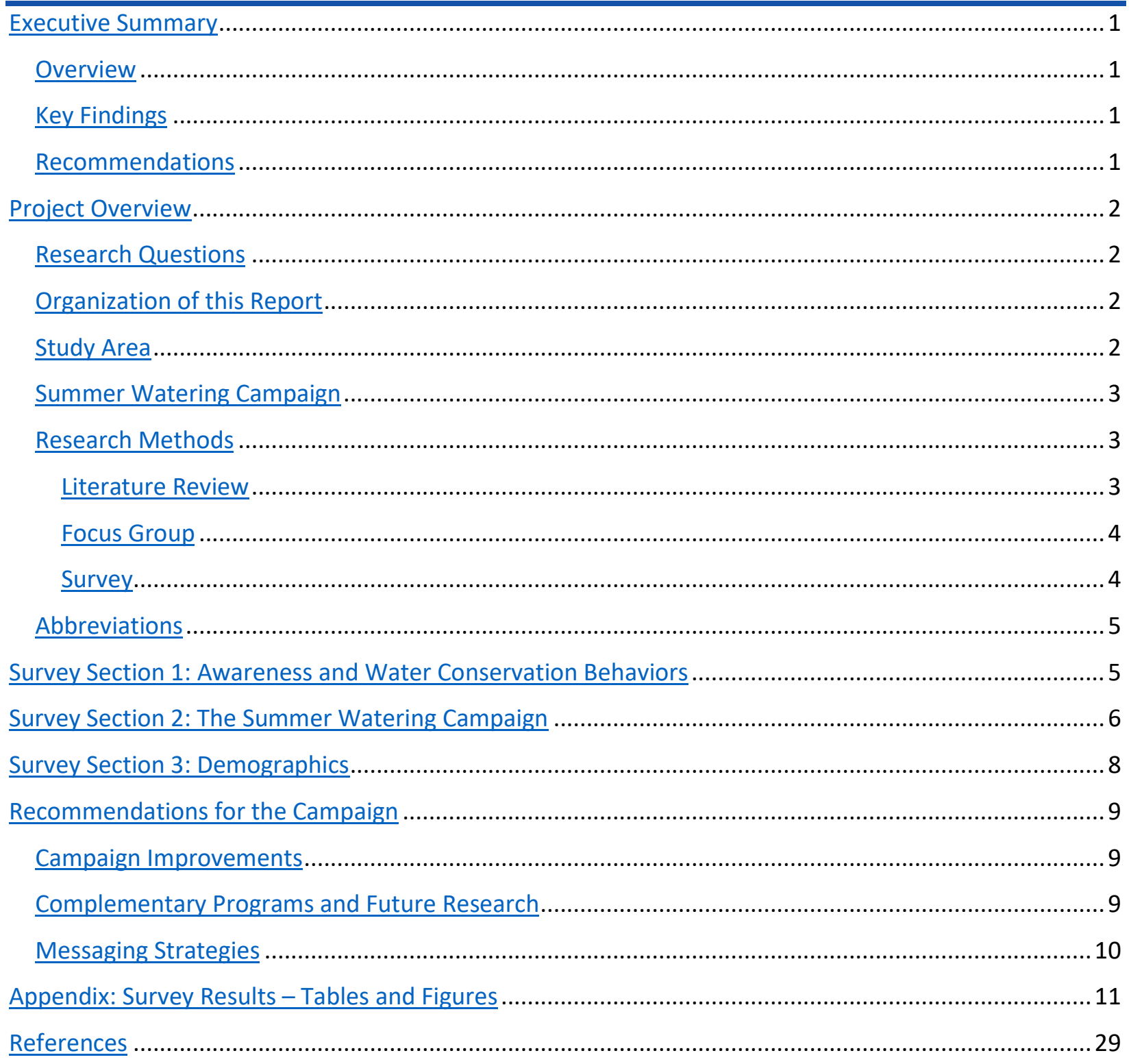

\section{Acknowledgments}

Christine and Kim, Clackamas River Water Providers

We would also like to thank the 317 people who participated in the focus group and survey and took the time to share their opinions and ideas with us to make this research possible. We are grateful for their input in this project to improve the summer watering campaign to benefit the watershed and the people and ecosystems who depend on the Clackamas River.

Cover photo by U.S. Forest Service, image is public domain. 


\section{Executive Summary}

\section{Overview}

This research project, a collaboration between Portland State University and Clackamas River Water Providers (CRWP), was conducted to evaluate CRWP's summer watering campaign to make recommendations for improvements. Data were gathered for this project through focus group and survey research. Recommendations to improve the campaign were made based on the findings of the focus group and survey as well as a literature review of water conservation and other environmental messaging campaigns designed to create large-scale behavior change.

\section{Key Findings}

\section{AWARENESS}

- Awareness has increased - a higher percentage of people reported knowing their drinking water comes from the Clackamas River compared to a previous survey

- People who knew the source of their water beforehand were generally more aware of issues within the watershed

- A quarter of participants had heard of the campaign before taking the survey

\section{MOTIVATION}

- People's motivation to conserve was not affected by different framings of the campaign message used in the survey

- Political values predict engagement with the campaign - liberals ranked their motivation higher than conservatives and were more likely to act and ask for more information

- Behaviors are influenced by a person's values, perceived personal efficacy, and social norms

\section{Recommendations}

1. Use multiple framings of the campaign message. Find messages that address each audience.

2. Use multiple messaging strategies to address different values and encourage behavior change from all audiences.

3. Increase awareness of the issues that make the campaign necessary (especially the summer drought). Explain why the Clackamas River is unique in its needs for water conservation. Make and share short videos and simple yet informative graphics.

4. Create a social identity around the shared water source and need for water conservation. Change the way green lawns are perceived in the area, especially during the summer drought.

5. Continue educational efforts. Make materials accessible year-round.

6. Monitor the results of this campaign to gauge engagement and participation.

7. Partner with local nurseries or home improvement stores to provide educational information about native or drought-tolerant plants to water users.

8. Work with local HOAs to change policies that will allow people to participate if desired.

9. Consider rephrasing the slogan, as "irrigation" confused people who did not associate the term with a residential yard or garden. 


\section{Project Overview}

The main goal of this project is to make recommendations to improve the Clackamas River Water Providers summer watering campaign based on data collected through focus group and survey research. The following report outlines relevant background information, methods, and results of this survey as well as recommendations for improving the campaign.

\section{Research Questions}

- How aware are water users of conservation issues in the Clackamas River and the water conservation messaging? What perceptions do water users have of the campaign?

- What motivates Clackamas River water users to conserve water? What are the underlying values or beliefs that influence their water conservation behaviors?

- How do environmental messaging campaigns use behavior theories to create behavior change? What types of strategies are often used and how effective are they?

\section{Organization of this Report}

This report begins with background information about the Clackamas River watershed, the summer watering campaign, and the research methods. Then, the survey is described in three sections. Each section description includes text outlining the focus of the questions asked within the section as well as a brief synthesis of their results. Following this are recommendations to improve the campaign, potential programs and future research, and messaging strategies to incorporate. The appendix contains detailed results for each survey question in tables and figures.

\section{Study Area}

The Clackamas River in Oregon is a drinking water source for over 300,000 people and is home to several species of endangered salmon. The Clackamas River Water Providers (CRWP) is a coalition of the eight water providers that source their water from the Clackamas River. This organization's purpose is to fund and coordinate source water protection efforts as well as public outreach and education regarding watershed issues, drinking water, and water conservation (1). In the past few years, CRWP has partnered with researchers at Portland State University to understand the potential impacts of climate change to future water supply $(2,3)$. The findings from the study contributed to CRWP's decision to implement a water conservation messaging campaign.

Several factors contribute to the need for increased water conservation in this watershed. First, there is no water storage on the Clackamas River, therefore water supply is dependent on natural river levels and flows. This poses a challenge at the end of summer and early fall especially if there is no fall rain. As there is little to no precipitation during the summer and early fall in this region, this dry season can be referred to as the "summer drought" and typically spans late August, September, and October. Outside of the summer drought, precipitation occurs throughout the watershed and creates a snowpack that can potentially supply water to the river into summer. CRWP anticipates that climate change will create longer and drier summers, and will cause more precipitation to fall as rain instead of snow thereby depleting the natural reservoir created by the slow-melting snowpack.

During the summer drought, demand for water is highest when supply is lowest: urban residential water users irrigate their yards and lawns to make up for the lack of rain, which results in 
water use tripling during this time. Additionally, endangered Coho and Fall Chinook salmon species are migrating upriver to spawn during late August, September and October. Minimum flow targets have been put into place to protect the spawning salmon during this time. Though these minimum flow targets have yet to be enforced, future changes to conditions mean it will be crucial to balance supply and demand.

\section{Summer Watering Campaign}

As part of their preparations for anticipated low flows during future summers, CRWP created a water conservation messaging campaign that premiered August of 2019. A common strategy to create behavior change is the use of focused messaging campaigns that inform the general public of an issue and attempt to create a specific behavioral change. The messaging of the CRWP's campaign, which can be seen in Figure 1, focuses on the endangered salmon that live in the Clackamas River and features the slogan "Fish on the run, irrigation

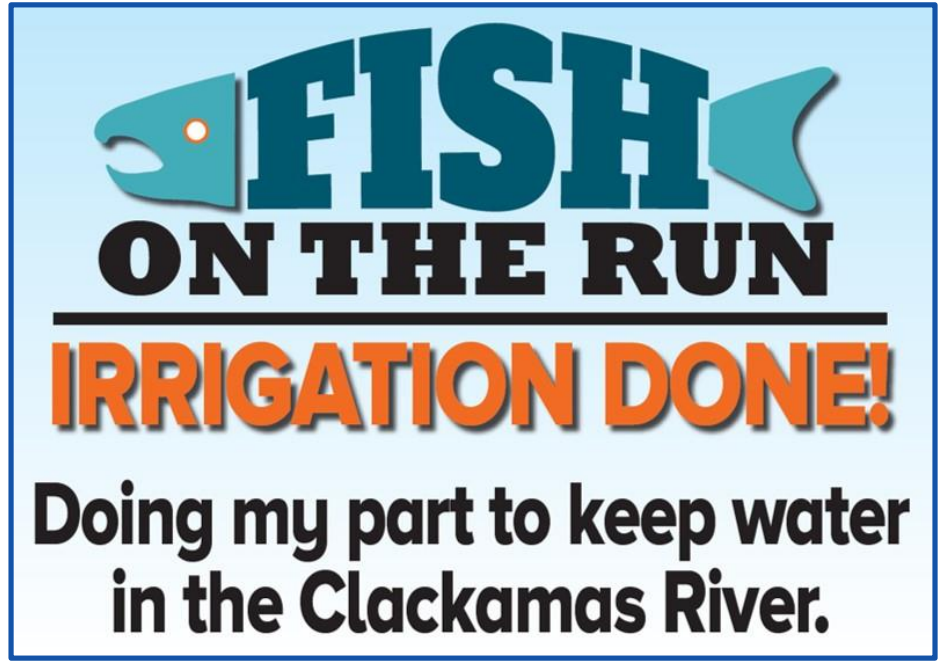

Figure 8. This graphic shows the slogan of the summer watering campaign, "Fish on the run, irrigation done!" and includes a message that demonstrates that a water user is conserving water and participating in the campaign. done!" (4). The goal of the campaign is to reduce water use during the summer drought (late summer and early fall months) primarily through the reduction of outdoor watering. Water users are encouraged to sign pledge cards that include a checklist of ways they plan on reducing their water use hat are primarily irrigation-oriented but also include indoor water conservation strategies. Water users who complete pledge cards receive a yard sign displaying the campaign slogan and website link that can help explain the appearance of their dormant brown lawn to neighbors. In addition to the main slogan and pledge cards, the campaign website provides educational materials regarding both indoor and outdoor water conservation methods. The campaign is designed to be promoted during the summer drought when the need for water conservation is highest, then to be quietly shelved during the wet parts of the year so water users don't become desensitized to the message.

CRWP plans to run this campaign for the next several years following an adaptive management strategy, meaning improvements and adjustments may be made each year to ensure the message is as effective as possible. Ideally, adopting water reduction behaviors during the summer drought would become the norm, and the campaign would simply remind and reinforce the behaviors. In its first year of circulation, the campaign was promoted through local newspaper advertisements, in-person public outreach, as well as within various municipal newsletters distributed in the service areas. CRWP did not have a large budget for promoting the campaign and would have expanded this effort if funding was available.

\section{Research Methods}

\section{Literature Review}

Through a review of behavior theory and environmental messaging campaign literature, I identified key concepts and theories that serve as the foundation of this research project, as they are 
used to interpret the focus group and survey findings as well as identify the campaign's messaging strategies. By reviewing other studies of water conservation and environmental messaging campaigns, I was able to categorize the strategies and techniques used in CRWP's campaign, and to make comparisons with other messaging types, strategies, and campaigns.

To better understand the process of adopting new behaviors, I reviewed the Theory of Planned Behavior (5) and the theory of the Diffusion of Innovations (6). These theories demonstrate the importance of an individual's values, self-efficacy, perception of social norms, and knowledge as components of their decision-making process when adopting new behaviors, like water conservation behaviors. These theories were used to analyze the data gathered by the focus group and survey.

\section{Focus Group}

The first portion of this research project consisted of a focus group held on the evening of October 8, 2019. To find participants for this focus group, CRWP board members created a short list of community members who were active volunteers in their local community who may or may not have a background in water issues. Attendance was determined by schedule availability. There were seven participants representing six of the nine water providers.

Discussion during the focus group was centered around the participants awareness of local issues, perception of the campaign, motivation for action, and barriers to action. Over the course of the two-and-a-half-hour focus group, participants, CRWP representatives, and researchers were able to have an in-depth conversation about water issues in the Clackamas River watershed that contribute to the need for water conservation. As the participants' understanding of the issues changed, so did their attitudes towards the campaign. Findings from the focus group-especially the observed shift in understanding and attitudes-were used to develop the survey questions.

\section{Survey}

The survey was conducted online; it was first sent out on January 24, 2020 and was completed on March 3, 2020. The sampled population consists of the customers of the water providers who source their drinking water from the Clackamas River. The survey was emailed to 660 water users who provided their emails to CRWP after participating in the organization's water conservation rebate program. Though Lake Oswego and Tigard are part of CRWP, these water providers have independent rebate programs and their customers were not included on the main email list. As these customers could not be reached via email, a separate link to the survey was created and shared by the water providers' social media accounts to ensure the survey would reach customers from all water providers. Between January and March of 2020, the email list was contacted multiple times and the survey link was distributed via the social media accounts of all water providers. In total, 320 people participated in the survey, and 288 surveys were fully completed. About two-thirds of the responses came from the email list, and one third came from the social media link. For full detailed results, see the Appendix.

Several questions within this survey were duplicated from a previous survey conducted in 2016 by PSU student Daniel Larson. These questions were asked again to help identify any changes in customer responses, particularly awareness of the source of their drinking water, lawn care practices and beliefs, and water conservation behaviors. Please note that the populations surveyed are different: the 2016 survey was a random sample of water users, but this survey primarily sampled rebate program participants. 


\section{Abbreviations}

For ease of data dissemination, the survey results have been organized into water provider groups based on geography and sample size. Table 1 contains the abbreviations used to represent these water provider groups within the various tables and figures in this report.
Table 6. Abbreviations of grouped water providers as they are used to report data in this document.

\begin{tabular}{|ll|}
\hline Abbreviation & Water Providers \\
\hline CRW & Clackamas River Water District \\
\hline SWA & $\begin{array}{l}\text { Sunrise Water Authority } \\
\text { SFWB }\end{array}$ \\
$\begin{array}{ll}\text { South Fork Water Board (West } \\
\text { Linn and Oregon City) }\end{array}$ \\
\hline LO & $\begin{array}{l}\text { City of Lake Oswego } \\
\text { Oak Lodge Water Services } \\
\text { City of Gladstone }\end{array}$ \\
TEU & $\begin{array}{l}\text { City of Tigard } \\
\text { City of Estacada } \\
\text { Unsure }\end{array}$ \\
\hline
\end{tabular}

\section{Survey Section 1: Awareness and Water Conservation Behaviors}

The first few questions of the survey were designed to act as a warmup and to get participants thinking about both the Clackamas River watershed as well as general water conservation. Participants were first asked to identify their water provider (Figure 2), followed by whether or not they had previously known that the Clackamas River was the source of their drinking water and how aware they were about several issues within the watershed. There was a series of questions asking respondents to choose the extent to which they agreed or disagreed with statements about lawn appearance and both indoor and outdoor water conservation behaviors. Additionally, this section gathered information about the areas within peoples' residence that are watered during the summer and early fall, the frequency of watering, and what methods people use to water these areas (see Appendix for results).

The results of this section show that source water awareness may have increased since the last survey of a similar population of water users in 2016 . The 2016 survey reported that $27 \%$ of randomly selected water users did not previously know their drinking water came from the Clackamas River, but this survey shows that number dropping to $20 \%$, meaning water users are potentially becoming more aware of the source of their drinking water. However, this result could be due to characteristics of this survey population. As homeowners who have participated in the rebate program, this survey population is engaged with their water provider and is likely to know more about their water. This survey also showed that water users who knew the source of their drinking water were generally more aware of water issues within the watershed.

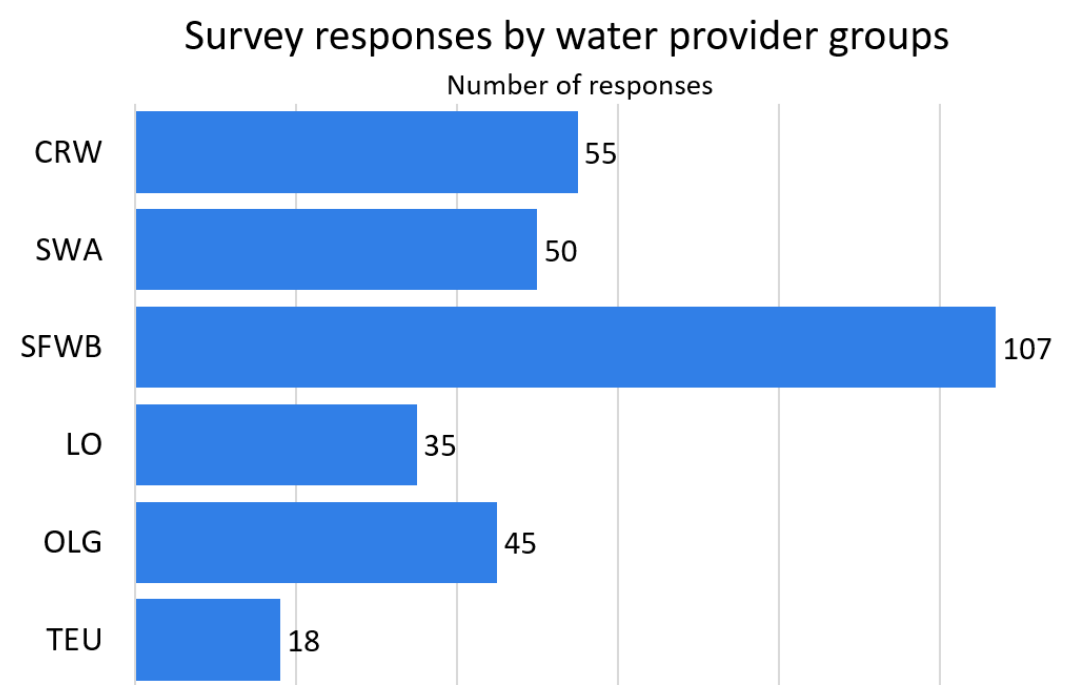

Figure 9. This figure shows the number of survey responses within each water provider group. See Table 1 for abbreviations. 


\section{Survey Section 2: The Summer Watering Campaign}

The next set of questions focused on the summer watering campaign. First, respondents were shown a graphic from the campaign (the same graphic as Figure 1) alongside an explanation of the issues driving the need for this water conservation campaign. This explanation was presented as one of three different framings that were randomly distributed to each participant:

an environmental framing that focused on ecosystem and salmon species needs for water, a regulatory framing that described the minimum flow targets and possibility of water restrictions, and a minimal framing that acted as a control and offered no additional information.

After viewing the campaign graphic and framing, the participant was asked whether they had previously heard of the campaign and where they had learned about it, how motivated they felt based on the campaign message, and how likely they felt they were to complete various water conservation and water reduction actions and practices in the next year. The actions and practices listed were taken from the campaign's pledge actions or educational materials. Additionally, participants were given the option to share their email if they wanted to receive additional information about various water conservation actions and opportunities. These two questions-perceived likelihood of action and request for more information-were important variables in the analysis as they identified the portion of the participants who were most engaged with water conservation ideas. The final question of this section gave participants the option to share any comments or ideas they had about the campaign.

The idea for the different framings of the campaign message used in this section originated from the focus group discussion, when participants' motivations and perceptions of the campaign changed throughout the discussion as they learned more about the issues contributing to the need for the campaign. The survey results did not show a significant difference on motivation, perceived likelihood of action, or a request for more information based on the framings. Overall, about three quarters of participants had not heard of the campaign before the survey. Just over half of participants rated themselves as feeling "somewhat" motivated by the campaign, with less than a quarter of participants reporting themselves as "extremely" or "very" motivated, and a quarter of participants rating themselves as "not very" or "not at all" motivated (see Question 11 in Appendix). Additionally, there is a relationship between motivation and how highly participants valued their lawns (Question 8, first statement). The higher a participant ranked their values towards a well-manicured green lawn, the lower their reported motivation score.

Both the comments of survey Question 13 and the focus group discussion were analyzed through thematic coding. The most prevalent themes and sub-themes are outlined in Table 2 alongside quotes from the survey or focus group that represent the theme. The four broad themes identified were personal efficacy (meaning how effective an individual perceives their efforts to be in aiding with the overall goal), individual values and beliefs, awareness, and responsibility. The first three themes align with the key components of behavior change identified in the Theory of Planned Behavior and the theory of the Diffusion of Innovations. The fourth theme, responsibility, includes the three levels of water users that can affect change: the individual water user, the community of water users, and the water providers and governing agencies who use and regulate water use. 
Table 7. This table shows the main themes and sub-themes identified in the focus group discussion and the survey comments (Question 13). Some quotes have been paraphrased to save space.

\begin{tabular}{|c|c|c|}
\hline Theme & Sub Themes & Quote from focus group or survey participant \\
\hline \multirow[t]{2}{*}{ Personal efficacy } & HOAs & $\begin{array}{l}\text { Reach out to area HOAs and encourage them to lax their 'visually } \\
\text { appealing' rules for lawns during the campaign months. Many of them } \\
\text { send letters to homeowners to 'fix the visual appeal of your yard'. }\end{array}$ \\
\hline & $\begin{array}{l}\text { Small vs. big } \\
\text { water user }\end{array}$ & $\begin{array}{l}\text { [The retirement community]'s irrigation system is on all the time. It's } \\
\text { raining and the irrigation is on! And people are driving up River Road } \\
\text { thinking 'what good is my little postage stamp of a property? Why should } \\
\text { I conserve?' }\end{array}$ \\
\hline \multirow[t]{4}{*}{$\begin{array}{l}\text { Individual values } \\
\text { and beliefs }\end{array}$} & $\begin{array}{l}\text { Personal } \\
\text { choice/ } \\
\text { freedom }\end{array}$ & $\begin{array}{l}\text { Although I would like to participate, our sprinkler system is automatically } \\
\text { controlled by our HOA. In that sense, my hands are tied. (I don't even think } \\
\text { I am allowed to put up a campaign sign out in front of my townhouse.) }\end{array}$ \\
\hline & $\begin{array}{l}\text { False } \\
\text { drought }\end{array}$ & $\begin{array}{l}\text { I understand monitoring water usage. However, I am definitely against } \\
\text { a "big brother" campaign that tells people how they can live on their } \\
\text { property. We live proudly in Oregon, a State, that has large rivers and } \\
\text { annual rainfall that should not require the measures you mention in } \\
\text { this survey. }\end{array}$ \\
\hline & $\begin{array}{l}\text { Money } \\
\text { (rebates \& } \\
\text { incentives) }\end{array}$ & $\begin{array}{l}\text { Make the restrictions mandatory and fine people who don't change their } \\
\text { watering habits. Think about the recent changes with plastic shopping } \\
\text { bags. There was a small incentive to bring your own bags to the store } \\
\text { before they started charging for plastic bag usage, but when it was } \\
\text { changed, suddenly everyone is buying reusable bags. This campaign } \\
\text { needs the law to treat water usage the same way. }\end{array}$ \\
\hline & Gardening & $\begin{array}{l}\text { I grow vegetables in my garden. If the pledge were modified to cover yards } \\
\text { and ornamental gardens, I would sign up. Growing our own food is also an } \\
\text { important value. }\end{array}$ \\
\hline \multirow[t]{2}{*}{ Awareness } & Education & $\begin{array}{l}\text { I think education is key. I love conservation when it serves a purpose. I } \\
\text { honestly had no idea that water levels in the Clackamas River were a } \\
\text { problem and that it could affect fish and wildlife. I have always believed } \\
\text { that "hey we live in rainy Oregon so water conservation isn't that } \\
\text { important". Now that I know that we need to conserve water to protect } \\
\text { our habitats during dry seasons, I will endeavor to do a better job } \\
\text { conserving water. }\end{array}$ \\
\hline & $\begin{array}{l}\text { Lawn } \\
\text { alternatives }\end{array}$ & $\begin{array}{l}\text { [I would like more] information about switching my lawn to drought } \\
\text { resistant landscaping. I'm interested in doing this, but have had a hard } \\
\text { time figuring out how and with which plants. }\end{array}$ \\
\hline \multirow[t]{3}{*}{ Responsibility } & $\begin{array}{l}\text { Individual } \\
\text { responsibility }\end{array}$ & $\begin{array}{l}{[\mathrm{lam}] \text { specifically interested in more efficient ways to water my }} \\
\text { vegetable garden, or an analysis if maintaining a vegetable garden is } \\
\text { responsible or not. }\end{array}$ \\
\hline & $\begin{array}{l}\text { Community } \\
\text { responsibility }\end{array}$ & $\begin{array}{l}\text { Don't make decisions behind closed doors without involving the } \\
\text { community. }\end{array}$ \\
\hline & $\begin{array}{l}\text { Agency } \\
\text { responsibility }\end{array}$ & $\begin{array}{l}\text { Here's the real problem: Gladstone sold water rights it owned (that were } \\
\text { not backed by actual river water flows) to Tigard and Lake Oswego who } \\
\text { then invested in a diversion pipeline from the Clackamas River to their } \\
\text { water systems. So now we have too many users that cannot be supported } \\
\text { by historic stream flows. This whole campaign is a band-aid to cover up a } \\
\text { really really bad water rights decision years ago. }\end{array}$ \\
\hline
\end{tabular}




\section{Survey Section 3: Demographics}

The final nine questions were general demographic questions that also originated from the 2016 survey conducted by Daniel Larson. The demographics gathered included gender, year of birth, number of years lived in Clackamas County, household annual income, education, home ownership, residence type, and political ideology. Though audience demographics are not something that CRWP can affect, knowing the audience of a messaging campaign is essential to effective communication.

The portion of Clackamas County sampled in this survey differs from the overall county and water provider service area population. As seen in Table 3, participants of this survey had a higher percentage of home ownership, reported higher household income, and are older than the Clackamas County population as found in the 2018 census (7). As this survey was primarily sent out to water users who had participated in CRWP's rebate program, these observed differences are not unexpected. Since homeowners have the ability and financial incentive to make improvements to their property, it's much more likely for homeowners to participate in rebate programs such as CRWP's.

Table 8. This table compares US Census data from 2018 with results from this survey (7). Not all demographics were measured in comparable ways.

\begin{tabular}{|lrr|}
\hline Demographic & US Census Data - 2018 & Survey Data \\
\hline Home ownership & $71 \%$ & $95 \%$ \\
Median household income & $\$ 81,278$ & $\$ 112,499$ \\
Median age & 41 & 56 \\
\hline
\end{tabular}

Past environmental conservation survey research at PSU has shown that demographics and political ideology are the biggest predictors of an individual's willingness to participate in environmental programs (8), and this remained true for this survey. In this study, political ideology was an indicator of a participant's motivation, perceived likelihood of action, and engagement. In Figure 3, it's clear that participants who labeled themselves as liberal were up to $150 \%$ more likely to state that they would definitely adopt one of the water conservation actions and were about $60 \%$ more likely to request additional information. Liberals also rated their motivation higher than conservatives and above the overall average motivation rating.

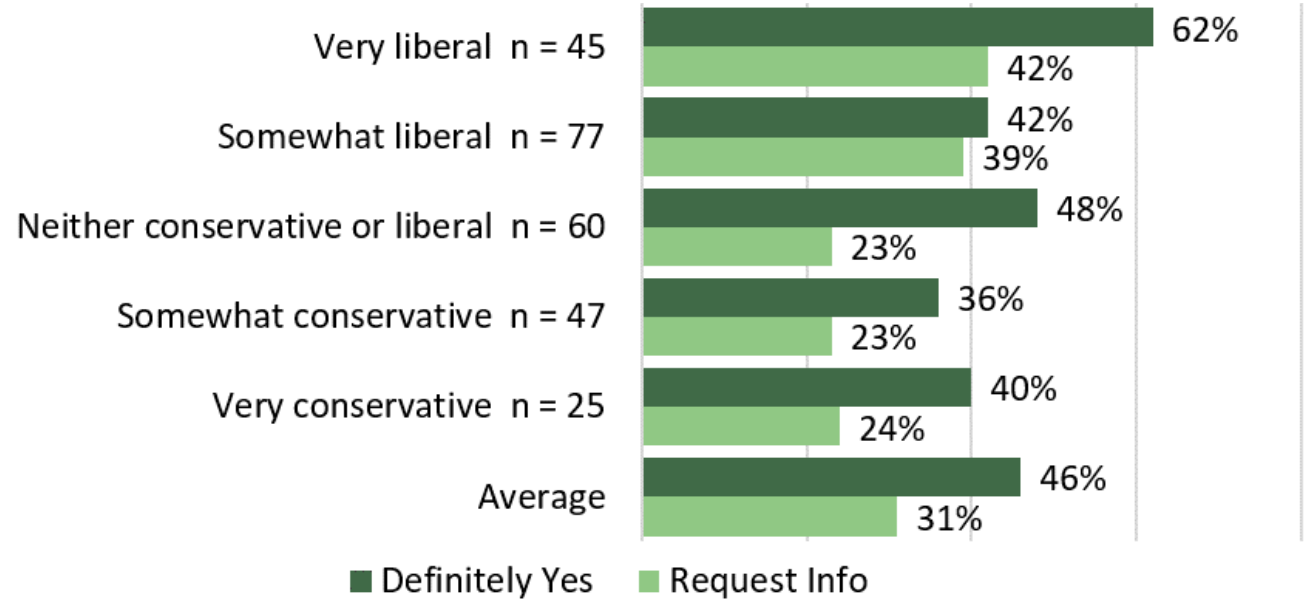

Figure 10. This figure shows the percent of participants within each political identity who marked definitely yes on any of the action statements in Question 12 and who requested additional information in Question 15. 


\section{Recommendations for the Campaign}

\section{Campaign Improvements}

- Increase awareness of the campaign as well as the need and various options for water conservation.

- Explain why the Clackamas River is unique in its need for water conservation.

- Use catchy and interesting social media posts with pictures or very short videos.

- Video demonstrations of water conservation practices

- Water level graphics, similar to well-known fire danger signs

- Address the different audiences in the area by using multiple framings of the message to focus on specific components of the issues that align with various values people hold.

- Values observed in this research: drinking water, lawns, money, gardening, effective use of water, personal choice, and ecosystem health.

- Some people have pre-existing ideas of water availability (false drought in Table 2) and may utilize this belief to reject any contradicting information they receive through messaging campaigns $(9,10)$. But it may be possible to motivate them to conserve by addressing specific values and helping them understand the unique needs for water use reduction during the summer drought.

- Continue public education in schools to instill environmental values and habits.

- Consider rephrasing the slogan, as "irrigation" confused people who did not associate the term with a residential yard or garden.

- Make educational materials accessible year-round instead of taking the campaign website offline during the rainy season.

\section{Complementary Programs and Future Research}

- Change the way green lawns are perceived in the area, especially during the summer drought. Research the cultural shifts regarding lawns that have occurred in various cities in the US.

- Monitor the results of this campaign. Do the number of pledges increase each summer? Does water use decrease? If water use data is available, compare water use between summers of specific users who took the campaign pledge.

- Create more financial incentives to reduce water use. Expand the rebate program if possible.

- Partner with local nurseries or home improvement stores to provide educational information about native or drought-tolerant plants to water users. Offer these businesses advertisement in your newsletters in exchange for a discount to verified water users.

- Work with local HOAs to change policies that will allow people to participate if desired.

- Though $70 \%$ of participants reported they were not a member of an HOA or similar organization, many comments indicated that people felt unable to conserve due to their HOA's rules. This demonstrates that this problem - though experienced by just under a third of participants-is perceived as a major barrier to water conservation. 


\section{Messaging Strategies}

The survey results showed no significant difference in people's reactions to the different framings. This means that CRWP is free to use multiple framings of the campaign message in order to connect with different audiences by targeting specific values, focusing on a specific issue in the watershed, and drawing attention to the benefits of reducing water use during the summer drought.

As outlined in Table 4, there are many strategies used in environmental messaging campaigns and CRWP can utilize more than one (11). The campaign of 2019 used several strategies including policies, direct request, commitment, conservation tips, and referrals and redirections. To help this campaign grow into a social norm and become part of the identity of Clackamas River water users, CRWP is advised to use messages that focus on the unique aspects of the watershed that make it different from other local watersheds and that lead to the need for water use reductions during the summer drought. By adding the messaging strategies of social norms, social identity, evidence of drought, and loss aversion, CRWP can communicate the unique challenges faced within the Clackamas watershed and can create a social identity around the shared water source. This can lead to a cultural shift around water conservation, local water issues, and perceptions around green lawns during the summer drought.

Table 9. This table is adapted from the findings of Liang et al (2018) who studied water conservation campaigns in California during a recent drought.

\begin{tabular}{|l|l|l|l|l|l}
\hline Messaging strategy & $\begin{array}{l}\text { Conceptual definition } \\
\text { Referrals and redirections }\end{array}$ & $\begin{array}{l}\text { Provides the receiver with content, tips, and/or strategies to save water } \\
\text { Dolicies }\end{array}$ & $\begin{array}{l}\text { Describes any rules, regulations, laws, mandatory restrictions, and } \\
\text { monetary exchanges for some conservation actions }\end{array}$ \\
\hline Goal-setting & $\begin{array}{l}\text { Provides a clear reference point to meet or surpass } \\
\text { Loss aversion }\end{array}$ & $\begin{array}{l}\text { Conveys to the receiver that inadequate conservation efforts will result } \\
\text { in consequences, usually limited water supply }\end{array}$ \\
\hline Evidence of drought & $\begin{array}{l}\text { Offers some concrete evidence, often in data or pictorial elements, to } \\
\text { encourage conservation behavior }\end{array}$ \\
\hline Social identity & $\begin{array}{l}\text { Heightens the awareness of the receiver's group membership and } \\
\text { conveys how behavior change will positively affect that group }\end{array}$ \\
\hline Humor & $\begin{array}{l}\text { Catches attention by inducing a receiver's positive reaction } \\
\text { Instructs the audience to conserve without any support or justification }\end{array}$ \\
\hline Direct request & $\begin{array}{l}\text { Asks the receiver to demonstrate a willingness to conserve water, } \\
\text { privately and/or publicly }\end{array}$ \\
\hline Commitment & $\begin{array}{l}\text { Describe the desired behavior as common and favorable amongst the } \\
\text { individual's community }\end{array}$ \\
\hline Social norms & $\begin{array}{l}\text { Similar to social norms but uses another social group as a comparison } \\
\text { and benchmark }\end{array}$ \\
\hline Social comparison &
\end{tabular}




\section{Appendix: Survey Results - Tables and Figures}

Question 1 - Who is your water provider?

See Figure 2 in Section 1 for a bar chart of response numbers by water provider group.

Table 10. Shows the percentage of responses from each water provider group.

\begin{tabular}{|lllllll|} 
Provider & CRW & SWA & SFWB & LO & OLG & TEU \\
\hline $\mathbf{n}=\mathbf{3 1 0}$ & $18 \%$ & $16 \%$ & $35 \%$ & $11 \%$ & $15 \%$ & $6 \%$ \\
\hline
\end{tabular}

Question 2 - Prior to receiving this survey, did you know that your tap water comes from the Clackamas River?

Table 11. This table shows the percentage of participants who did or did not know the Clackamas River was the source of their drinking water, by water provider and overall.

\begin{tabular}{|llllllll|} 
Provider & CRW & SWA & SFWB & LO & OLG & TEU & Total \\
& $n=55$ & $n=50$ & $n=107$ & $n=35$ & $\begin{array}{l}n=45 \\
n=18\end{array}$ & $n=310$ \\
\hline No & $13 \%$ & $28 \%$ & $18 \%$ & $31 \%$ & $16 \%$ & $22 \%$ & $20 \%$ \\
Yes & $87 \%$ & $72 \%$ & $82 \%$ & $69 \%$ & $84 \%$ & $78 \%$ & $80 \%$ \\
\hline
\end{tabular}

Question 3 - On a scale of 1 to 4, please rank how important you believe the following values are to the communities in the Clackamas River basin. (1 being the most important, and 4 being of lesser importance.)

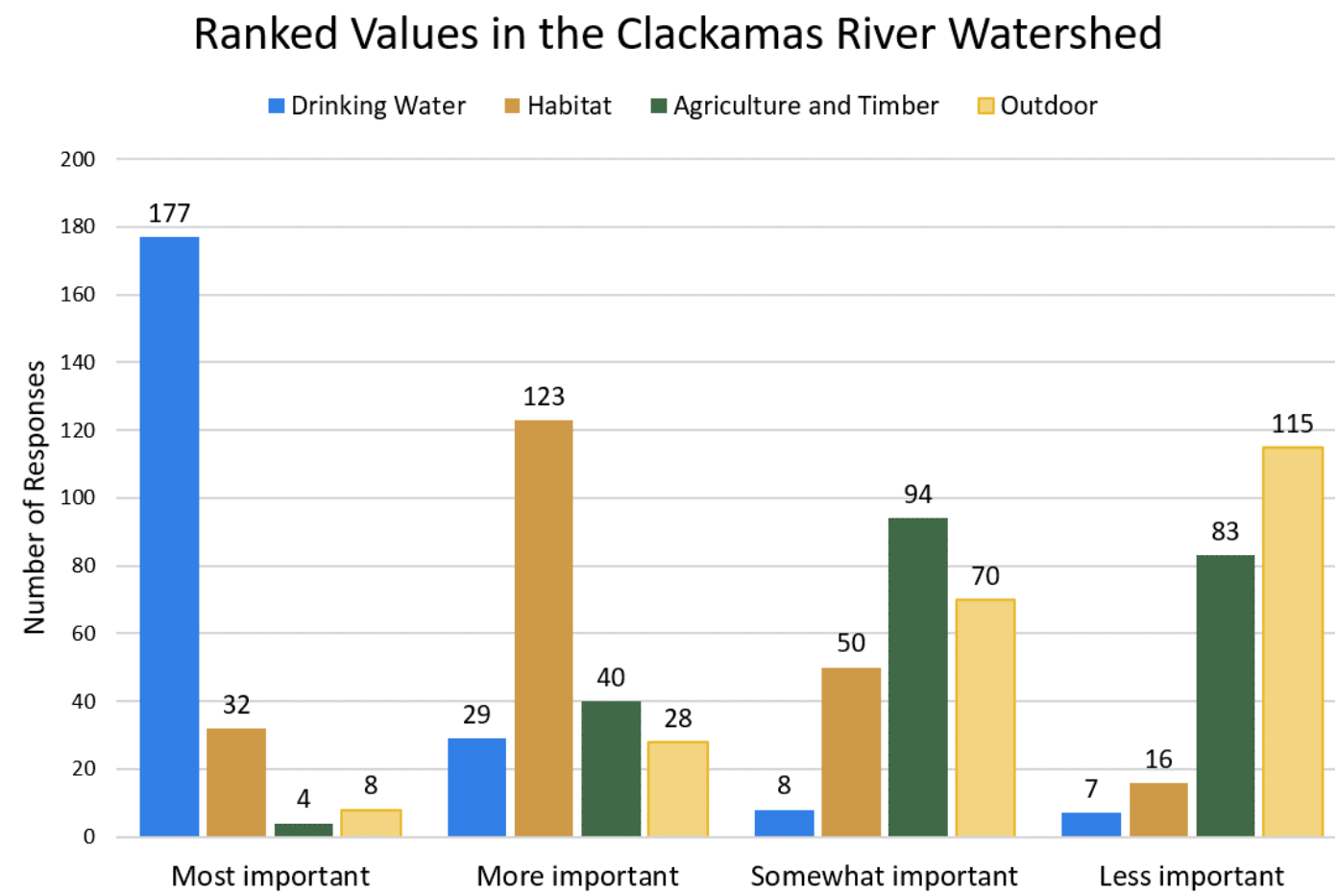

Figure 11. This figure shows the way participants ranked the four values provided in the question: drinking water, habitat, agriculture and timber, and outdoor recreation. $N=221$. 


\section{Question 4 - How aware are you of the following issues in the Clackamas River watershed? How aware are you of the following issues in the Clackamas River watershed? \\ very aware $\quad$ Somewhat aware \\ $\square$ Not very aware $\quad$ Not at all aware}

Protected fish live and spawn in the Clackamas River (e.g., salmon and steelhead).

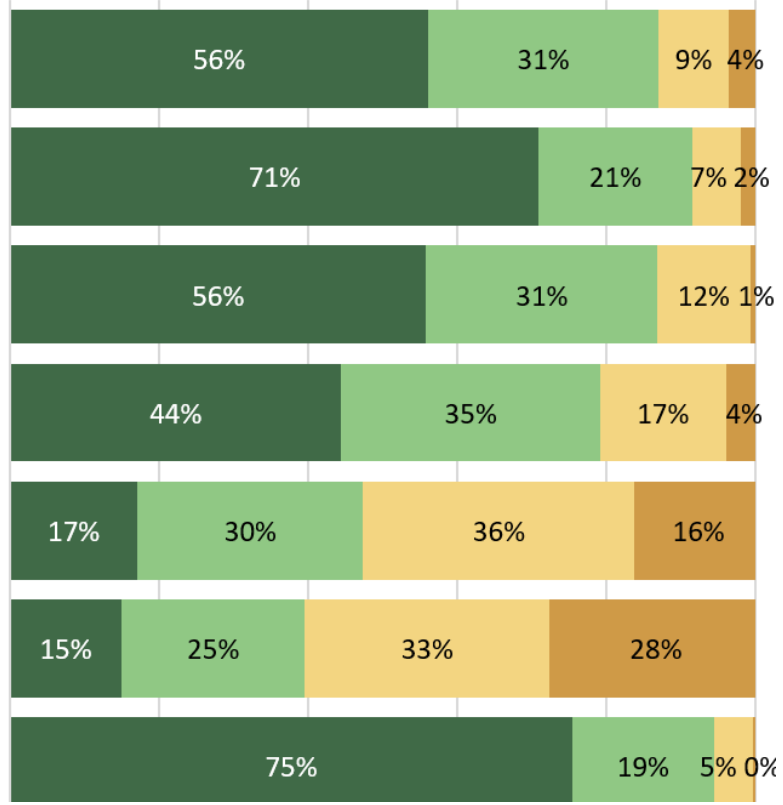

A grass lawn can go dormant and turn brown during the dry season but will turn green again once the rainy season starts.

Figure 12. This figure displays the overall responses to Question 4.

Table 12. This table shows the percent of participants from each water provider group who responded they were "Very aware" of the listed issue from Question 4.

\begin{tabular}{|c|c|c|c|c|c|c|c|}
\hline & $\begin{array}{l}\text { CRW } \\
n=54\end{array}$ & $\begin{array}{l}\text { SWA } \\
n=50\end{array}$ & $\begin{array}{l}\text { SFWB } \\
n=107\end{array}$ & $\begin{array}{l}\mathrm{LO} \\
\mathrm{n}=36\end{array}$ & $\begin{array}{l}\text { OLG } \\
n=45\end{array}$ & $\begin{array}{l}\text { TEU } \\
n=18\end{array}$ & $\begin{array}{l}\text { Total } \\
\mathrm{n}=\mathbf{3 1 0}\end{array}$ \\
\hline $\begin{array}{l}\text { Protected fish live and spawn in the } \\
\text { Clackamas River (e.g., salmon and } \\
\text { steelhead). }\end{array}$ & $44 \%$ & $50 \%$ & $62 \%$ & $50 \%$ & $71 \%$ & $50 \%$ & $56 \%$ \\
\hline $\begin{array}{l}\text { Clackamas River flows are lowest during the } \\
\text { summer and early fall. }\end{array}$ & $72 \%$ & $66 \%$ & $72 \%$ & $58 \%$ & $84 \%$ & $56 \%$ & $71 \%$ \\
\hline $\begin{array}{l}\text { Water use triples during summer due to } \\
\text { outdoor water use. }\end{array}$ & $56 \%$ & $54 \%$ & $57 \%$ & $58 \%$ & $44 \%$ & $67 \%$ & $56 \%$ \\
\hline $\begin{array}{l}\text { Summer water use can affect the quantity of } \\
\text { water flowing in the Clackamas River. }\end{array}$ & $39 \%$ & $46 \%$ & $39 \%$ & $44 \%$ & $53 \%$ & $61 \%$ & $44 \%$ \\
\hline $\begin{array}{l}\text { The Clackamas River has summer time } \\
\text { targets to maintain minimum flows in the } \\
\text { river for fish and water quality. }\end{array}$ & $11 \%$ & $16 \%$ & $19 \%$ & $17 \%$ & $24 \%$ & $11 \%$ & $17 \%$ \\
\hline $\begin{array}{l}\text { Future water use could be legally restricted } \\
\text { if late summer flows in the Clackamas River } \\
\text { fall below the minimum flow targets } \\
\text { repeatedly over several years. }\end{array}$ & $11 \%$ & $20 \%$ & $15 \%$ & $14 \%$ & $16 \%$ & $11 \%$ & $15 \%$ \\
\hline $\begin{array}{l}\text { A grass lawn can go dormant and turn } \\
\text { brown during the dry season but will turn } \\
\text { green again once the rainy season starts. }\end{array}$ & $76 \%$ & $80 \%$ & $72 \%$ & $81 \%$ & $73 \%$ & $78 \%$ & $75 \%$ \\
\hline
\end{tabular}


Question 5 - During the summer (dry season), do you water any of the following areas within your residence? (Please mark areas you water, not just areas you have.)

\section{Areas watered during the summer and fall dry season}

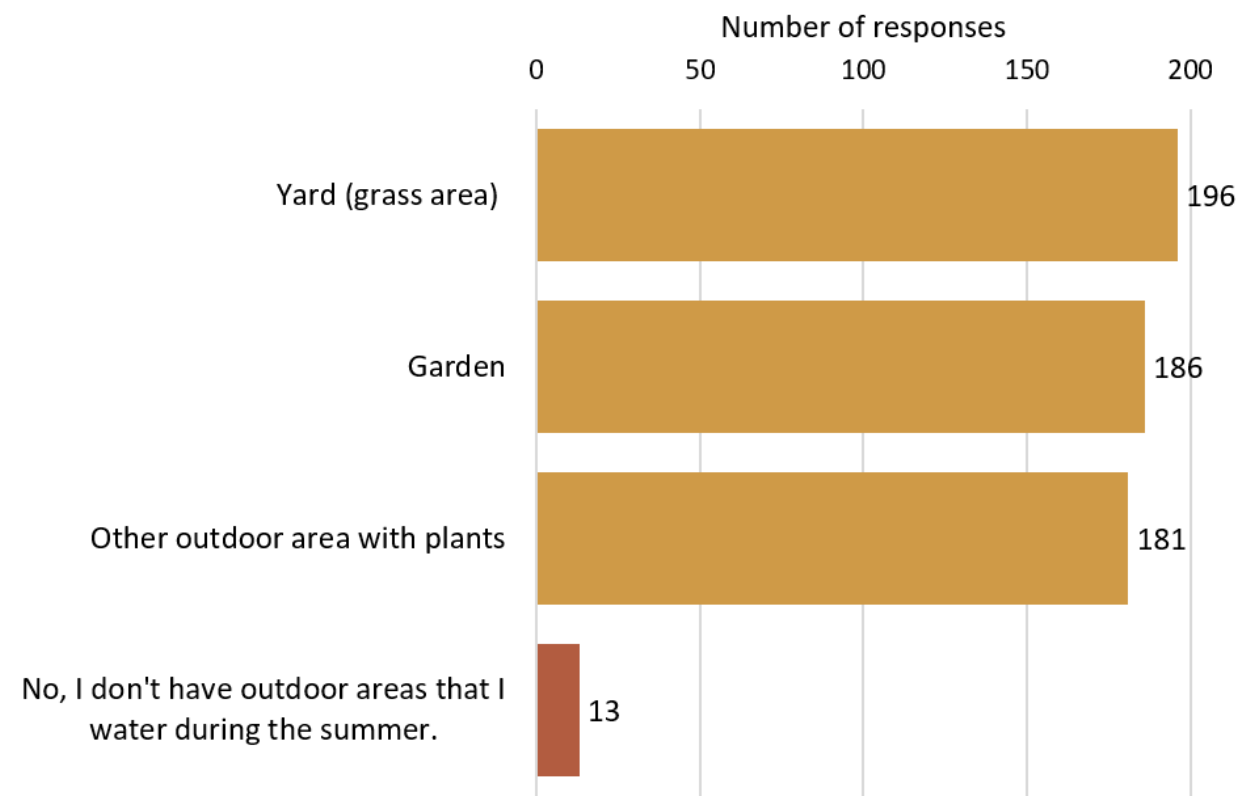

Figure 13. This figure displays the areas that participants water during the dry season. Responses in red show those who do not water.

Table 13. This table shows what areas participants water during the dry season. Participants were able to select more than one option.

\begin{tabular}{|c|c|c|c|c|c|c|c|}
\hline & $\begin{array}{l}\text { CRW } \\
n=53\end{array}$ & $\begin{array}{l}\text { SWA } \\
n=49\end{array}$ & $\begin{array}{l}\text { SFWB } \\
n=105\end{array}$ & $\begin{array}{l}L O \\
n=35\end{array}$ & $\begin{array}{l}\text { OLG } \\
n=45\end{array}$ & $\begin{array}{l}\text { TEU } \\
n=17\end{array}$ & $\begin{array}{l}\text { Total } \\
n=304\end{array}$ \\
\hline Yard (grass area) & 32 & 40 & 76 & 18 & 22 & 201 & 196 \\
\hline Garden & 35 & 25 & 64 & 21 & 26 & 198 & 186 \\
\hline Other outdoor area with plants & 29 & 25 & 64 & 22 & 32 & 189 & 181 \\
\hline $\begin{array}{l}\text { No, I don't have outdoor areas that I } \\
\text { water during the summer. }\end{array}$ & 2 & 1 & 4 & 2 & 3 & 14 & 13 \\
\hline
\end{tabular}


Question 6 - During the summer and early fall dry season, how often do you typically water your yard or garden?

\section{Watering frequency}

Every day

Every other day

Once a week

- Once or twice a month

Less than once a month (I let my outdoor areas go dormant)

- I don't have a yard, garden, or other area that I water.

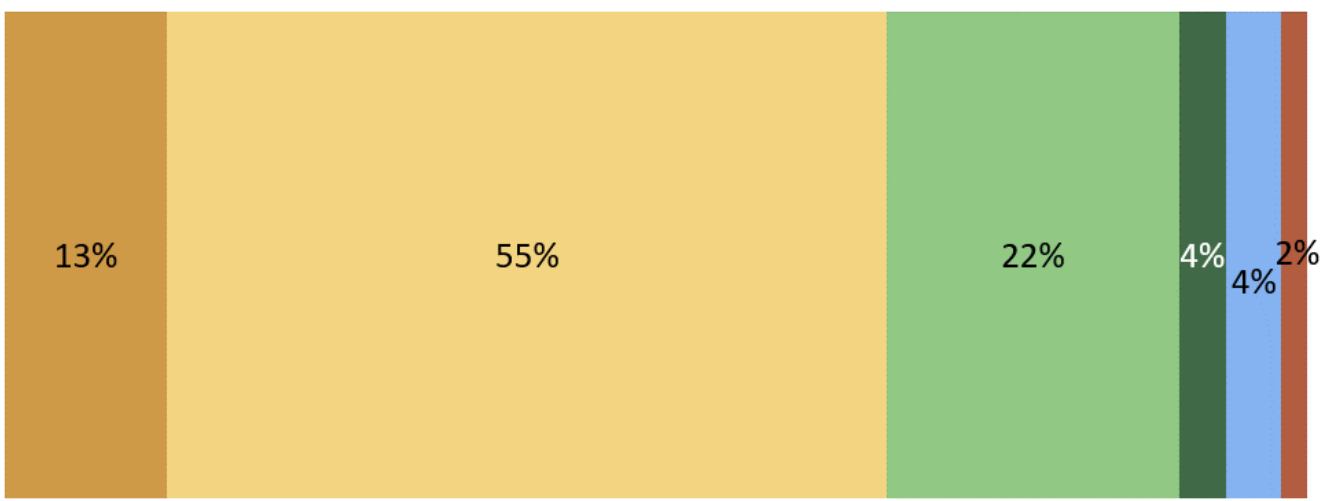

Figure 14. This figure shows the overall responses to Question 6 which asks about watering frequency.

Table 14. This table shows the responses to Question 6 or the frequency at which people water during the dry season, by water provider group.

\begin{tabular}{|c|c|c|c|c|c|c|c|}
\hline & $\begin{array}{l}\text { CRW } \\
n=53\end{array}$ & $\begin{array}{l}\text { SWA } \\
n=49\end{array}$ & $\begin{array}{l}\text { SFWB } \\
n=105\end{array}$ & $\begin{array}{l}\mathrm{LO} \\
\mathrm{n}=35\end{array}$ & $\begin{array}{l}\text { OLG } \\
n=45\end{array}$ & $\begin{array}{l}\text { TEU } \\
\mathrm{n}=17\end{array}$ & $\begin{array}{l}\text { Total } \\
n=304\end{array}$ \\
\hline Every day & $11 \%$ & $12 \%$ & $14 \%$ & $20 \%$ & $9 \%$ & $0 \%$ & $13 \%$ \\
\hline Every other day & $47 \%$ & $69 \%$ & $56 \%$ & $49 \%$ & $49 \%$ & $65 \%$ & $55 \%$ \\
\hline Once a week & $32 \%$ & $12 \%$ & $22 \%$ & $23 \%$ & $24 \%$ & $18 \%$ & $22 \%$ \\
\hline Once or twice a month & $4 \%$ & $4 \%$ & $1 \%$ & $3 \%$ & $7 \%$ & $12 \%$ & $4 \%$ \\
\hline $\begin{array}{l}\text { Less than once a month (I let my } \\
\text { outdoor areas go dormant) }\end{array}$ & $4 \%$ & $2 \%$ & $3 \%$ & $3 \%$ & $11 \%$ & $6 \%$ & $4 \%$ \\
\hline $\begin{array}{l}\text { I don't have a yard, garden, or other } \\
\text { area that I water. }\end{array}$ & $2 \%$ & $0 \%$ & $4 \%$ & $3 \%$ & $0 \%$ & $0 \%$ & $2 \%$ \\
\hline
\end{tabular}


Question 7 - When you water your yard or garden, what type of watering system do you typically use? (Select all that apply.)

Watering methods

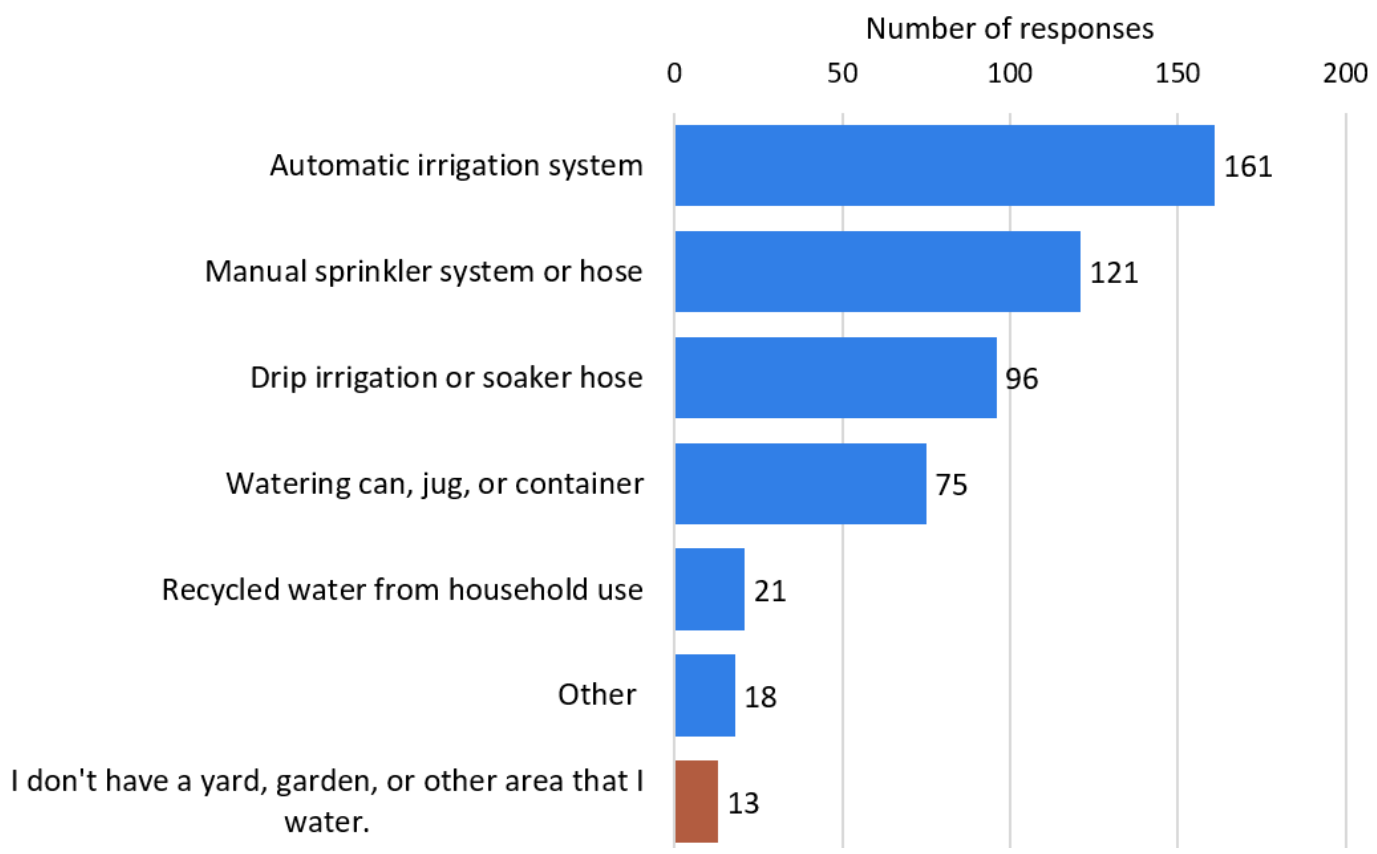

Figure 15. This bar chart shows the number of responses for each method of watering, as well as the responses indicating participants do not have an area to water (in red). These responses are shown in this format because multiple options were selected by some participants.

Table 15. This table shows the responses regarding watering methods by water provider group. Participants were able to select more than one option.

\begin{tabular}{|c|c|c|c|c|c|c|c|}
\hline & $\begin{array}{l}\text { CRW } \\
n=53\end{array}$ & $\begin{array}{l}\text { SWA } \\
n=49\end{array}$ & $\begin{array}{l}\text { SFWB } \\
n=105\end{array}$ & $\begin{array}{l}L O \\
n=35\end{array}$ & $\begin{array}{l}\text { OLG } \\
n=45\end{array}$ & $\begin{array}{l}\text { TEU } \\
n=17\end{array}$ & $\begin{array}{l}\text { Total } \\
n=305\end{array}$ \\
\hline Automatic irrigation system & 24 & 35 & 65 & 16 & 15 & 6 & 161 \\
\hline Manual sprinkler system or hose & 28 & 17 & 34 & 14 & 21 & 7 & 121 \\
\hline Drip irrigation or soaker hose & 14 & 15 & 33 & 9 & 17 & 8 & 96 \\
\hline Watering can, jug, or container & 13 & 11 & 23 & 9 & 13 & 6 & 75 \\
\hline Recycled water from household use & 5 & 5 & 1 & 4 & 4 & 2 & 21 \\
\hline Other & 3 & 1 & 7 & 3 & 2 & 2 & 18 \\
\hline $\begin{array}{l}\text { I don't have a yard, garden, or other } \\
\text { area that I water. }\end{array}$ & 2 & 0 & 5 & 2 & 3 & 1 & 13 \\
\hline
\end{tabular}


Question 8- How much do you agree or disagree with the following statements about yard and lawn maintenance?

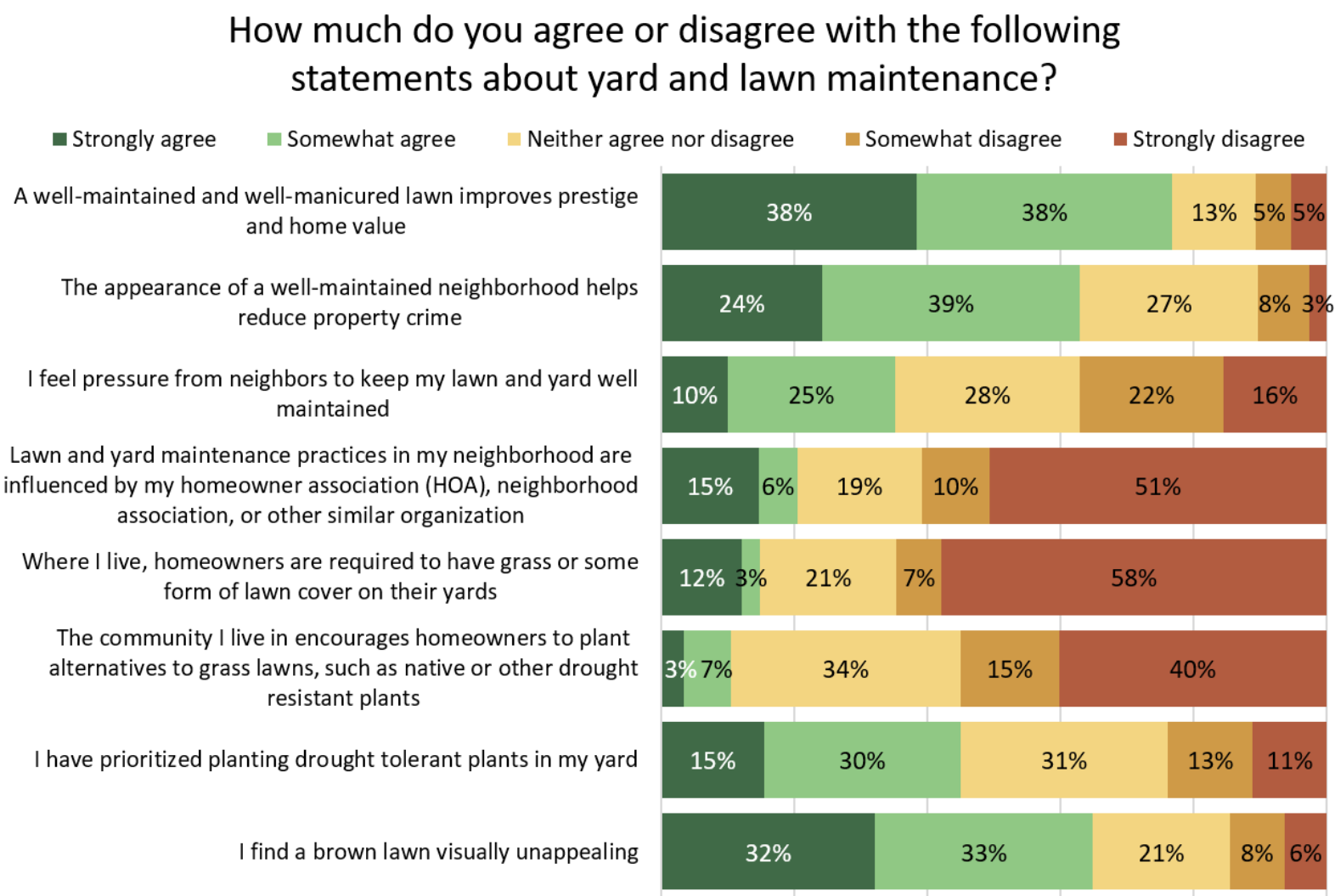

Figure 16. This figure shows the overall responses to statements about yard and lawn maintenance in Question 8.

Table 16. This table shows the percent of participants that marked "Strongly agree" or "Somewhat agree" for each statement, by water provider.

\begin{tabular}{|c|c|c|c|c|c|c|c|}
\hline & $\begin{array}{l}\text { CRW } \\
n=51\end{array}$ & $\begin{array}{l}\text { SWA } \\
n=49\end{array}$ & $\begin{array}{l}\text { SFWB } \\
n=105\end{array}$ & $\begin{array}{l}\mathrm{LO} \\
\mathrm{n}=34\end{array}$ & $\begin{array}{l}\text { OLG } \\
=45\end{array}$ & $\begin{array}{l}\text { TEU } \\
n=17\end{array}$ & $\begin{array}{l}\text { Total } \\
\mathrm{n}=301\end{array}$ \\
\hline $\begin{array}{l}\text { A well-maintained and well-manicured } \\
\text { lawn improves prestige and home value }\end{array}$ & $82 \%$ & $86 \%$ & $78 \%$ & $57 \%$ & $80 \%$ & $59 \%$ & $38 \%$ \\
\hline $\begin{array}{l}\text { The appearance of a well-maintained } \\
\text { neighborhood helps reduce property crime }\end{array}$ & $66 \%$ & $67 \%$ & $67 \%$ & $57 \%$ & $62 \%$ & $29 \%$ & $24 \%$ \\
\hline $\begin{array}{l}\text { I feel pressure from neighbors to keep my } \\
\text { lawn and yard well maintained }\end{array}$ & $27 \%$ & $41 \%$ & $38 \%$ & $40 \%$ & $24 \%$ & $41 \%$ & $10 \%$ \\
\hline $\begin{array}{l}\text { Lawn and yard maintenance practices in my } \\
\text { neighborhood are influenced by my } \\
\text { homeowner association (HOA), } \\
\text { neighborhood association, or other similar } \\
\text { organization }\end{array}$ & $20 \%$ & $37 \%$ & $20 \%$ & $27 \%$ & $4 \%$ & $6 \%$ & $15 \%$ \\
\hline $\begin{array}{l}\text { Where I live, homeowners are required to } \\
\text { have grass or some form of lawn cover on } \\
\text { their yards }\end{array}$ & $12 \%$ & $35 \%$ & $15 \%$ & $12 \%$ & $2 \%$ & $6 \%$ & $12 \%$ \\
\hline
\end{tabular}




\begin{tabular}{|l|ccccccc|}
\hline $\begin{array}{l}\text { The community I live in encourages } \\
\text { homeowners to plant alternatives to grass } \\
\text { lawns, such as native or other drought }\end{array}$ & $10 \%$ & $2 \%$ & $8 \%$ & $38 \%$ & $7 \%$ & $6 \%$ & $\mathbf{3 \%}$ \\
$\begin{array}{l}\text { resistant plants } \\
\text { I have prioritized planting drought tolerant } \\
\text { plants in my yard }\end{array}$ & $46 \%$ & $39 \%$ & $38 \%$ & $61 \%$ & $50 \%$ & $59 \%$ & $\mathbf{1 5 \%}$ \\
I find a brown lawn visually unappealing & $69 \%$ & $73 \%$ & $68 \%$ & $53 \%$ & $58 \%$ & $47 \%$ & $\mathbf{3 2 \%}$ \\
\hline
\end{tabular}

\section{Question 9-How much do you agree or disagree with the following statements about water conservation?}

How much do you agree or disagree with the

following statements about water conservation?

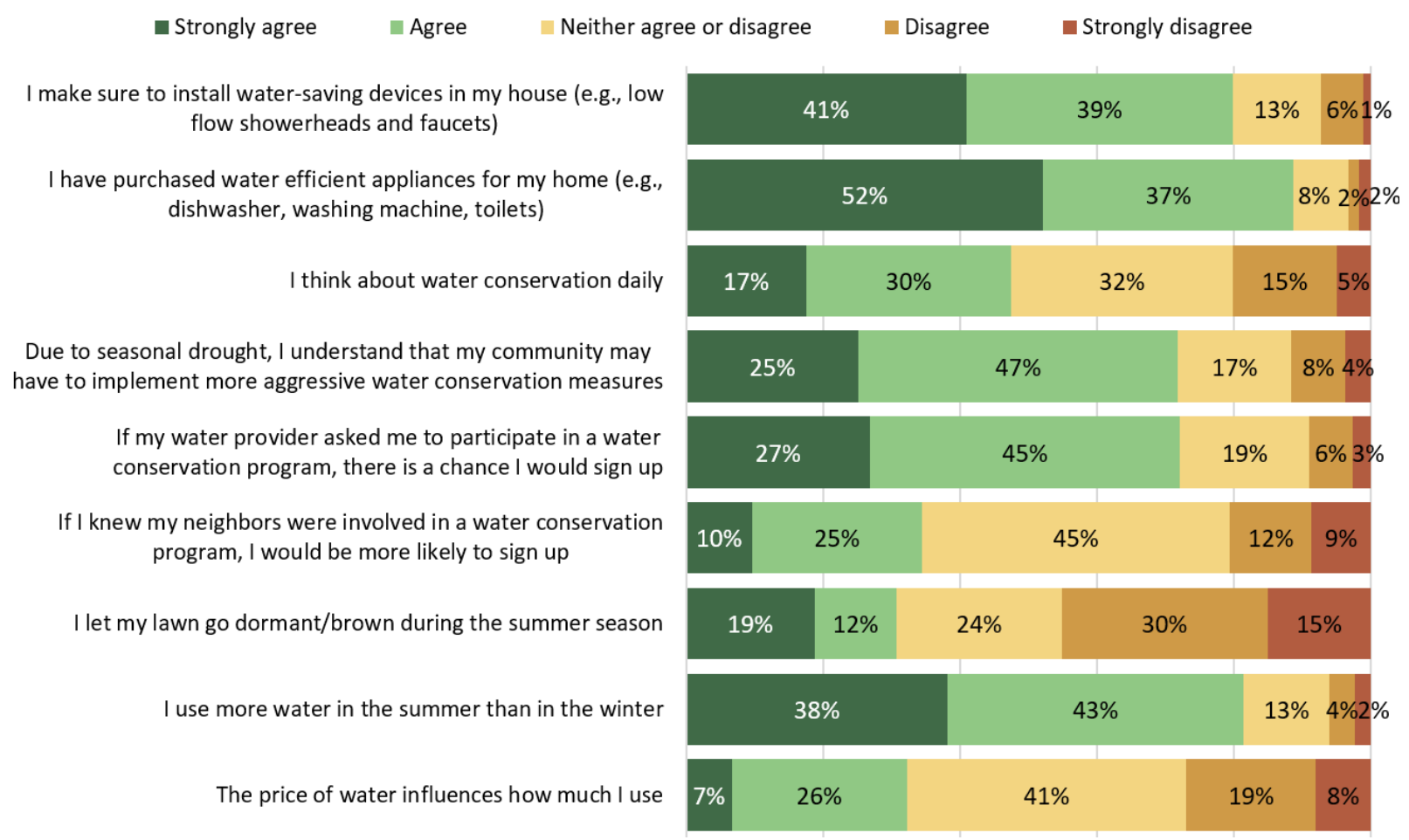

Figure 17. This figure shows the overall responses to Question 9.

Table 17. This table shows the percent of participants that marked "Strongly agree" or "Agree" for each water conservation statement, by water provider.

\begin{tabular}{|l|ccccccc|} 
& $\begin{array}{l}\text { CRW } \\
n=53\end{array}$ & $\begin{array}{l}\text { SWA } \\
n=49\end{array}$ & $\begin{array}{l}\text { SFWB } \\
n=104\end{array}$ & $\begin{array}{l}\text { LO } \\
n=34\end{array}$ & $\begin{array}{l}\text { OLG } \\
=45\end{array}$ & $\begin{array}{l}\text { TEU } \\
n=17\end{array}$ & $\begin{array}{l}\text { Total } \\
n=302\end{array}$ \\
\hline $\begin{array}{l}\text { I make sure to install water-saving } \\
\text { devices in my house (e.g., low flow } \\
\text { showerheads and faucets) }\end{array}$ & $79 \%$ & $82 \%$ & $77 \%$ & $86 \%$ & $82 \%$ & $76 \%$ & $\mathbf{8 0 \%}$ \\
$\begin{array}{l}\text { I have purchased water efficient } \\
\text { appliances for my home (e.g., }\end{array}$ & $91 \%$ & $94 \%$ & $87 \%$ & $86 \%$ & $91 \%$ & $76 \%$ & $\mathbf{8 9 \%}$ \\
$\begin{array}{l}\text { dishwasher, washing machine, toilets) } \\
\text { I think about water conservation daily }\end{array}$ & $60 \%$ & $43 \%$ & $41 \%$ & $49 \%$ & $44 \%$ & $65 \%$ & $\mathbf{4 7 \%}$ \\
\hline
\end{tabular}




\begin{tabular}{|c|c|c|c|c|c|c|c|}
\hline $\begin{array}{l}\text { Due to seasonal drought, I understand } \\
\text { that my community may have to } \\
\text { implement more aggressive water } \\
\text { conservation measures }\end{array}$ & $73 \%$ & $67 \%$ & $72 \%$ & $74 \%$ & $70 \%$ & $76 \%$ & $72 \%$ \\
\hline $\begin{array}{l}\text { If my water provider asked me to } \\
\text { participate in a water conservation } \\
\text { program, there is a chance I would sign } \\
\text { up }\end{array}$ & $75 \%$ & $78 \%$ & $66 \%$ & $80 \%$ & $69 \%$ & $76 \%$ & $72 \%$ \\
\hline $\begin{array}{l}\text { If I knew my neighbors were involved in a } \\
\text { water conservation program, I would be } \\
\text { more likely to sign up }\end{array}$ & $35 \%$ & $35 \%$ & $31 \%$ & $44 \%$ & $33 \%$ & $35 \%$ & $34 \%$ \\
\hline $\begin{array}{l}\text { I let my lawn go dormant/brown during } \\
\text { the summer season }\end{array}$ & $38 \%$ & $22 \%$ & $20 \%$ & $39 \%$ & $44 \%$ & $41 \%$ & $31 \%$ \\
\hline $\begin{array}{l}\text { I use more water in the summer than in } \\
\text { the winter }\end{array}$ & $79 \%$ & $82 \%$ & $85 \%$ & $88 \%$ & $69 \%$ & $82 \%$ & $81 \%$ \\
\hline $\begin{array}{l}\text { The price of water influences how much I } \\
\text { use }\end{array}$ & $29 \%$ & $33 \%$ & $31 \%$ & $41 \%$ & $29 \%$ & $35 \%$ & $32 \%$ \\
\hline
\end{tabular}

Question 10 - If you were aware of this campaign before now, please identify where you learned about it. (Please check all that apply.)

Have you seen or heard of this campaign before?

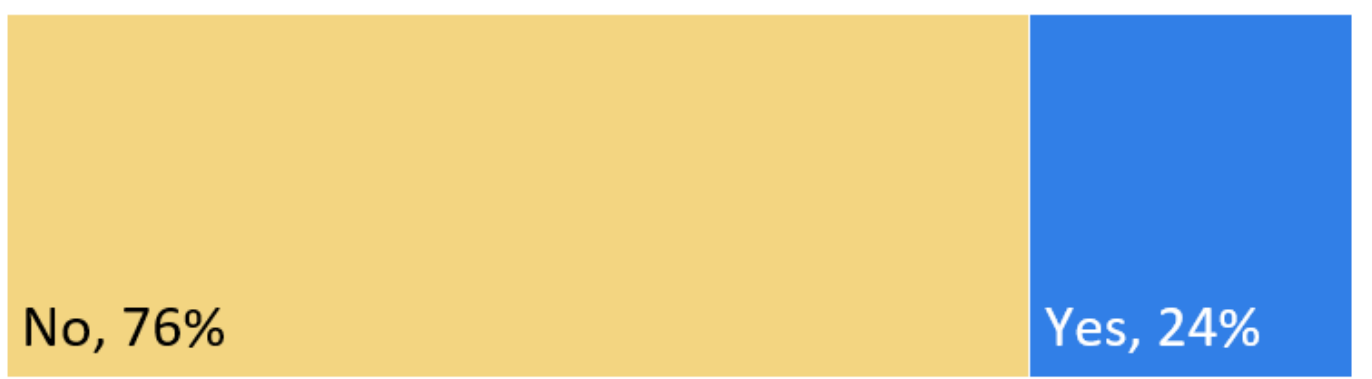

Figure 18. This figure shows the percentage of participants who had and had not seen or heard of the campaign before taking the survey.

Table 18. This table shows the percentage of participants within each water provider that had or had not heard of the campaign before the survey.

\begin{tabular}{|llllllll|}
\hline & $\begin{array}{l}\text { CRW } \\
n=52\end{array}$ & $\begin{array}{l}\text { SWA } \\
n=47\end{array}$ & $\begin{array}{l}\text { SFWB } \\
n=98\end{array}$ & $\begin{array}{l}\text { LO } \\
n=32\end{array}$ & $\begin{array}{l}\text { OLG } \\
n=42\end{array}$ & $\begin{array}{l}\text { TEU } \\
n=16\end{array}$ & $\begin{array}{l}\text { Total } \\
n=287\end{array}$ \\
\hline $\begin{array}{l}\text { No, I have not heard of this campaign } \\
\text { before now }\end{array}$ & $71 \%$ & $72 \%$ & $74 \%$ & $69 \%$ & $60 \%$ & $63 \%$ & $70 \%$ \\
$\begin{array}{l}\text { Yes, I have heard of this campaign } \\
\text { before now }\end{array}$ & $29 \%$ & $28 \%$ & $26 \%$ & $31 \%$ & $40 \%$ & $38 \%$ & $\mathbf{3 0 \%}$ \\
\hline
\end{tabular}


Table 19. This table shows the ways people had heard about the campaign, by water provider.

\begin{tabular}{|llllllll} 
& CRW & SWA & SFWB & LO & OLG & TEU & Total \\
Newsletter & 3 & 4 & 3 & 1 & 4 & 3 & $\mathbf{1 8}$ \\
Digital news advertisement & 0 & 0 & 0 & 2 & 1 & 1 & $\mathbf{4}$ \\
Website & 2 & 1 & 1 & 0 & 2 & 2 & $\mathbf{8}$ \\
Watering campaign yard sign & 0 & 0 & 0 & 0 & 0 & 0 & $\mathbf{0}$ \\
At an event & 0 & 1 & 0 & 0 & 3 & 0 & $\mathbf{4}$ \\
From my city or water provider & 7 & 4 & 7 & 4 & 5 & 0 & $\mathbf{2 7}$ \\
From a friend or family member & 0 & 1 & 2 & 0 & 2 & 0 & $\mathbf{5}$ \\
Not sure & 2 & 0 & 7 & 1 & 2 & 1 & $\mathbf{1 3}$ \\
Other & 1 & 1 & 1 & 0 & 2 & 0 & $\mathbf{5}$ \\
\hline
\end{tabular}

Question 11 - Based on the campaign messaging, how motivated are you to restrict or stop your outdoor water use during the dry season?

Based on on the campaign messaging, how motivated are you to restrict or stop your outdoor water use during the dry season?

$\begin{array}{ll}\square \text { Extremely motivated } & \square \text { Very motivated } \\ \square \text { Not very motivated } & \square \text { Not at all motivated }\end{array}$

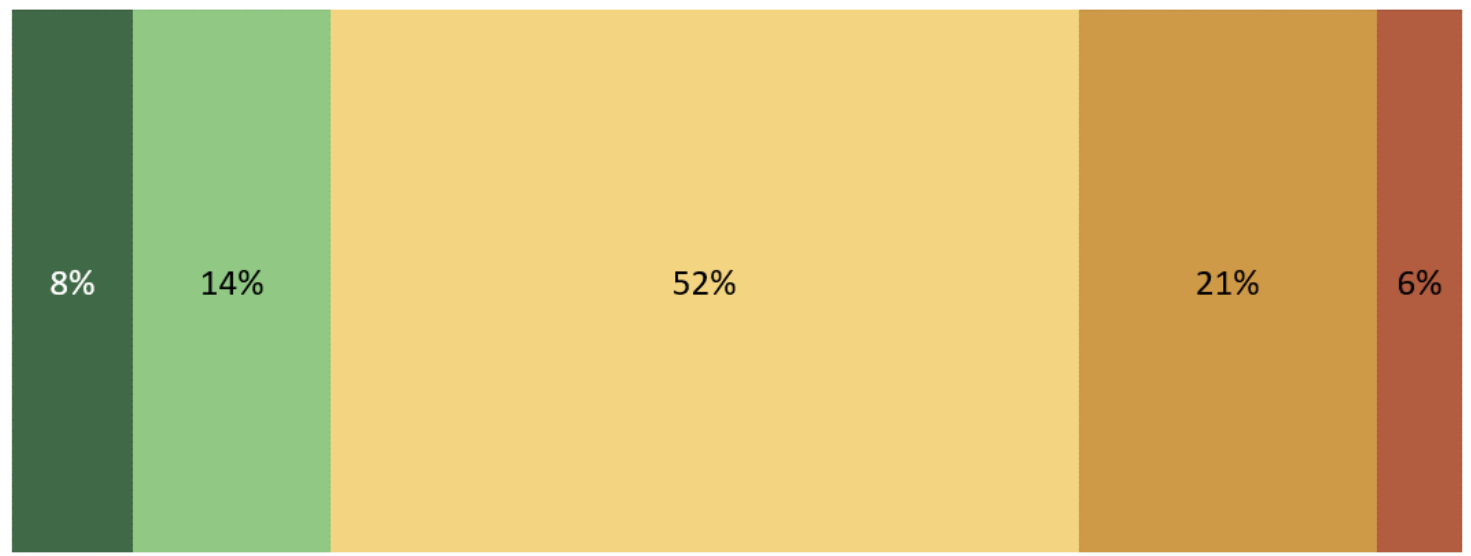

Figure 19. This figure shows the overall responses to Question 11.

Table 20. This table shows the responses regarding motivation by water provider.

\begin{tabular}{|c|c|c|c|c|c|c|c|}
\hline & $\begin{array}{l}\text { CRW } \\
n=52\end{array}$ & $\begin{array}{l}\text { SWA } \\
n=47\end{array}$ & $\begin{array}{l}\text { SFWB } \\
n=98\end{array}$ & $\begin{array}{l}\text { LO } \\
n=32\end{array}$ & $\begin{array}{l}\text { OLG } \\
n=42\end{array}$ & $\begin{array}{l}\text { TEU } \\
n=16\end{array}$ & $\begin{array}{l}\text { Total } \\
n=287\end{array}$ \\
\hline Not at all motivated & $13 \%$ & $2 \%$ & $9 \%$ & $6 \%$ & $12 \%$ & $0 \%$ & $8 \%$ \\
\hline Not very motivated & $4 \%$ & $15 \%$ & $18 \%$ & $6 \%$ & $17 \%$ & $19 \%$ & $14 \%$ \\
\hline Somewhat motivated & $52 \%$ & $64 \%$ & $48 \%$ & $50 \%$ & $45 \%$ & $56 \%$ & $52 \%$ \\
\hline Very motivated & $25 \%$ & $17 \%$ & $17 \%$ & $25 \%$ & $24 \%$ & $19 \%$ & $21 \%$ \\
\hline Extremely motivated & $6 \%$ & $2 \%$ & $7 \%$ & $13 \%$ & $2 \%$ & $6 \%$ & $6 \%$ \\
\hline
\end{tabular}


Question 12 - Do you think you will do any of the following actions at any point during the next year?

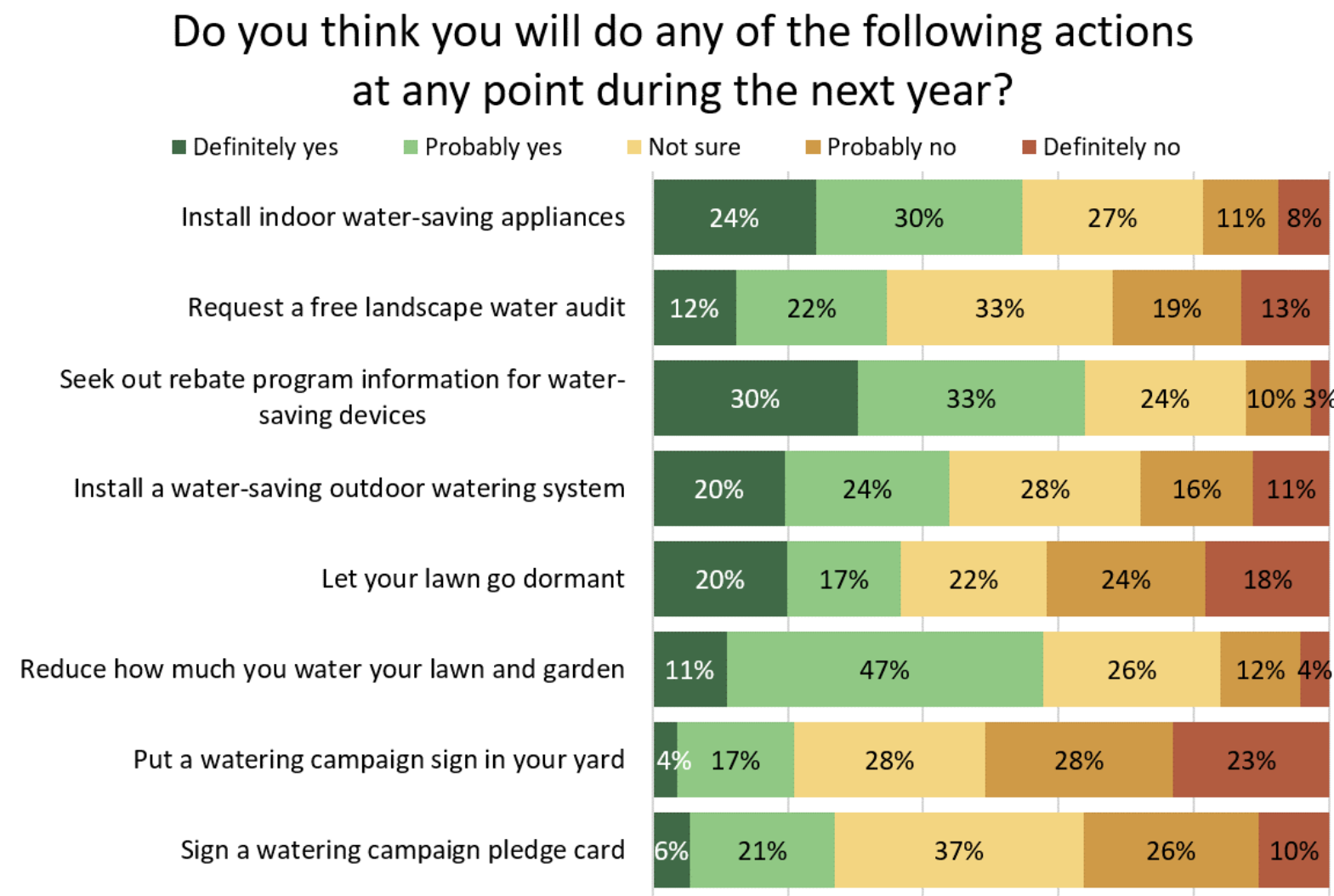

Figure 20. Shows the responses to Question 12.

Table 21. This table shows the percentage of participants who marked "Definitely yes" to at least one of the proposed actions, by water provider.

\begin{tabular}{|c|c|c|c|c|c|c|c|}
\hline & $\begin{array}{l}\text { CRW } \\
n=53\end{array}$ & $\begin{array}{l}\text { SWA } \\
n=47\end{array}$ & $\begin{array}{l}\text { SFWB } \\
n=98\end{array}$ & $\begin{array}{l}\mathrm{LO} \\
\mathrm{n}=31\end{array}$ & $\begin{array}{l}\text { OLG } \\
n=42\end{array}$ & $\begin{array}{l}\text { TEU } \\
n=16\end{array}$ & $\begin{array}{l}\text { Total } \\
n=288\end{array}$ \\
\hline $\begin{array}{l}\text { Percent of participants who marked } \\
\text { "Definitely yes" to any action }\end{array}$ & $55 \%$ & $53 \%$ & $43 \%$ & $42 \%$ & $48 \%$ & $44 \%$ & $47 \%$ \\
\hline
\end{tabular}

Table 22. This table shows the percentage of people by water provider who marked "Definitely yes" to the proposed actions.

\begin{tabular}{|lllllll|} 
& CRW & SWA & SFWB & LO & OLG & TEU \\
Sign a watering campaign pledge card & $9 \%$ & $2 \%$ & $4 \%$ & $8 \%$ & $7 \%$ & $0 \%$ \\
\hline $\begin{array}{l}\text { Put a watering campaign sign in your yard } \\
\text { Reduce how much you water your lawn and }\end{array}$ & $4 \%$ & $4 \%$ & $3 \%$ & $3 \%$ & $2 \%$ & $6 \%$ \\
$\begin{array}{l}\text { garden } \\
\text { Let your lawn go dormant }\end{array}$ & $13 \%$ & $14 \%$ & $7 \%$ & $11 \%$ & $7 \%$ & $11 \%$ \\
$\begin{array}{l}\text { Install a water-saving outdoor watering } \\
\text { system }\end{array}$ & $9 \%$ & $16 \%$ & $9 \%$ & $17 \%$ & $22 \%$ & $17 \%$ \\
\hline
\end{tabular}




\begin{tabular}{|lllllll|}
\hline $\begin{array}{l}\text { Seek out rebate program information for } \\
\text { water-saving devices }\end{array}$ & $29 \%$ & $32 \%$ & $21 \%$ & $28 \%$ & $18 \%$ & $28 \%$ \\
\hline $\begin{array}{l}\text { Request a free landscape water audit } \\
\text { Install indoor water-saving appliances }\end{array}$ & $7 \%$ & $4 \%$ & $17 \%$ & $8 \%$ & $11 \%$ & $6 \%$ \\
\hline
\end{tabular}

Question 13 - The Clackamas River Water Providers would like to improve the campaign. Are there any improvements you'd like to suggest or messaging topics you believe would work better? Please write in any ideas you'd like to share.

See Table 2 in Section 2 of the survey outline for themes and quotes from the survey comments and focus group discussion.

Question 14 - After reading the information in this survey, would you say your awareness of the following issues has changed?

After reading the information in this survey, would you say your awareness of the following issues has changed?

Much more aware $\quad$ Slightly more aware $\quad$ Same as before, not more aware

Protected fish live and spawn in the Clackamas River (e.g., salmon and steelhead).

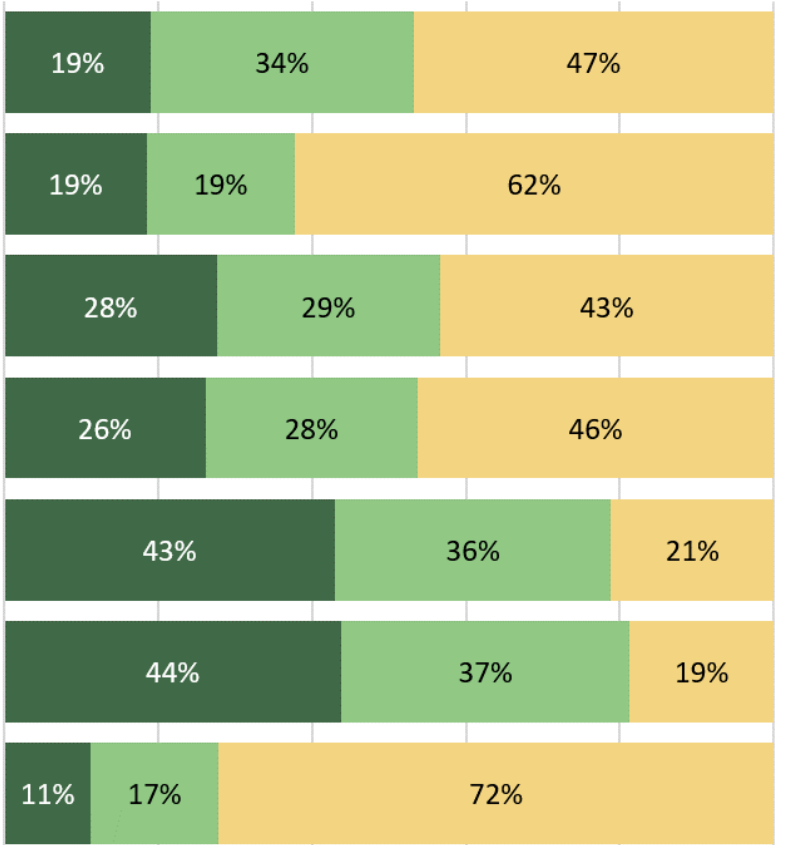

A grass lawn can go dormant and turn brown during the dry season but will turn green again once the rainy season starts.

Figure 21. This figure shows the overall responses to Question 14. 
Table 23. This table shows the percent of respondent who selected "much more aware" as their response.

\begin{tabular}{|c|c|c|c|c|c|c|}
\hline & $\begin{array}{l}\text { CRW } \\
n=51\end{array}$ & $\begin{array}{l}\text { SWA } \\
n=47\end{array}$ & $\begin{array}{l}\text { SFWB } \\
n=97\end{array}$ & $\begin{array}{l}\mathrm{LO} \\
\mathrm{n}=32\end{array}$ & $\begin{array}{l}\text { OLG } \\
n=42\end{array}$ & $\begin{array}{l}\text { TEU } \\
n=16\end{array}$ \\
\hline $\begin{array}{l}\text { Protected fish live and spawn in the Clackamas River } \\
\text { (e.g., salmon and steelhead). }\end{array}$ & $18 \%$ & $26 \%$ & $20 \%$ & $22 \%$ & $10 \%$ & $19 \%$ \\
\hline $\begin{array}{l}\text { Clackamas River flows are lowest during the summer } \\
\text { and early fall. }\end{array}$ & $22 \%$ & $21 \%$ & $16 \%$ & $19 \%$ & $17 \%$ & $13 \%$ \\
\hline $\begin{array}{l}\text { Water use triples during summer due to outdoor } \\
\text { water use. }\end{array}$ & $29 \%$ & $40 \%$ & $24 \%$ & $25 \%$ & $24 \%$ & $13 \%$ \\
\hline $\begin{array}{l}\text { Summer water use can affect the quantity of water } \\
\text { flowing in the Clackamas River. }\end{array}$ & $25 \%$ & $34 \%$ & $23 \%$ & $31 \%$ & $21 \%$ & $25 \%$ \\
\hline $\begin{array}{l}\text { The Clackamas River has summer time targets to } \\
\text { maintain minimum flows in the river for fish and } \\
\text { water quality. }\end{array}$ & $47 \%$ & $51 \%$ & $40 \%$ & $41 \%$ & $36 \%$ & $44 \%$ \\
\hline $\begin{array}{l}\text { Future water use could be legally restricted if late } \\
\text { summer flows in the Clackamas River fall below the } \\
\text { minimum flow targets repeatedly over several years. }\end{array}$ & $39 \%$ & $53 \%$ & $41 \%$ & $44 \%$ & $40 \%$ & $50 \%$ \\
\hline $\begin{array}{l}\text { A grass lawn can go dormant and turn brown during } \\
\text { the dry season but will turn green again once the } \\
\text { rainy season starts. }\end{array}$ & $10 \%$ & $19 \%$ & $10 \%$ & $16 \%$ & $7 \%$ & $0 \%$ \\
\hline
\end{tabular}

Question 15 - There are a number of options you have to learn more about what you can do to conserve water. If you are interested in learning more about rebate programs, landscape audits, and water conservation practices, please fill out your email and select the appropriate boxes below. Information will be sent to the email you provide within the next month or two. (Note: this is optional, your email will be kept separate from other survey data, and you will not receive any further emails regarding this survey.)

Table 24. This table shows the number and percentage of responses to Question 15.

\begin{tabular}{|lll|}
\hline Response option & $\%$ & $\mathbf{n}=$ \\
\hline No, I am not interested in receiving information. & $55 \%$ & 146 \\
\hline Yes, I am interested. (Please enter your email here.) & $35 \%$ & 94 \\
\hline Total & & $\mathbf{2 4 0}$ \\
\hline
\end{tabular}

Table 25. This table shows the number and percentage of participants who shared their email in Question 15, demonstrating their interest in receiving addition information.

\begin{tabular}{|c|c|c|}
\hline Water provider group & $\#$ & $\%$ \\
\hline CRW $n=48$ & 18 & $38 \%$ \\
\hline SWA $n=44$ & 13 & $30 \%$ \\
\hline SFWB $n=92$ & 38 & $41 \%$ \\
\hline LO $n=28$ & 10 & $36 \%$ \\
\hline OLG $n=39$ & 10 & $26 \%$ \\
\hline TEU $n=16$ & 5 & $31 \%$ \\
\hline Total $n=267$ & 94 & $35 \%$ \\
\hline
\end{tabular}


Table 26. This table shows the number of times each type of educational material was selected. Out of the 94 participants who answered this question positively, many selected multiple options.

\begin{tabular}{|lc|}
\hline Educational material & Number of times requested \\
\hline Indoor water-saving appliance rebate information & 27 \\
\hline Outdoor water-saving irrigation rebate information & 60 \\
Free outdoor landscape audits & 76 \\
Water conservation tips & 72 \\
\hline
\end{tabular}

Question 16 - Do you own, rent or lease your place of residence? Do you own, rent or lease your place of residence? @ Own $\square$ Rent or lease $\square$ Other

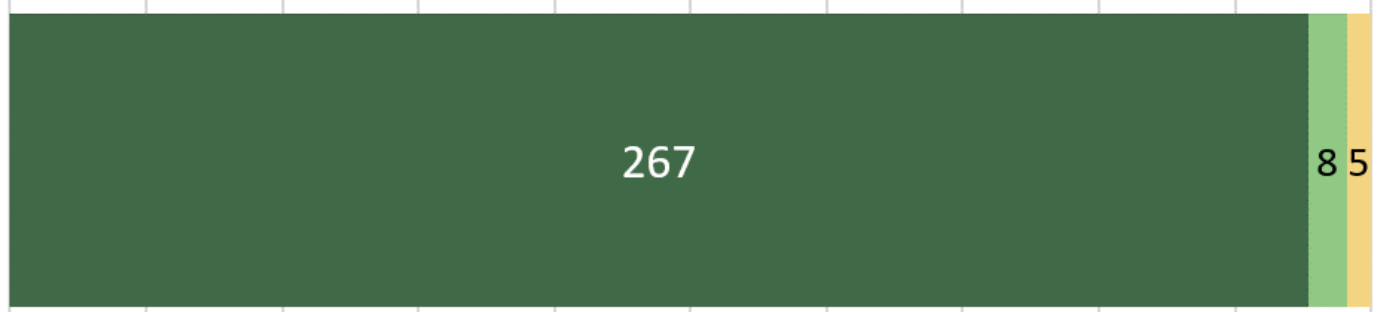

Number of responses

Figure 22. This figure shows the overall responses to Question 17.

Table 27. This table shows the responses to Question 17 as a percentage within each water provider group.

\begin{tabular}{|c|c|c|c|c|c|c|c|}
\hline & $\begin{array}{l}\text { CRW } \\
n=50\end{array}$ & $\begin{array}{l}\text { SWA } \\
n=46\end{array}$ & $\begin{array}{l}\text { SFWB } \\
n=97\end{array}$ & $\begin{array}{l}\text { LO } \\
n=31\end{array}$ & $\begin{array}{l}\text { OLG } \\
n=40\end{array}$ & $\begin{array}{l}\text { TEU } \\
n=15\end{array}$ & $\begin{array}{l}\text { Total } \\
n=280\end{array}$ \\
\hline Own & $94 \%$ & $98 \%$ & $94 \%$ & $94 \%$ & $100 \%$ & $93 \%$ & $95 \%$ \\
\hline Rent or lease & $0 \%$ & $2 \%$ & $6 \%$ & $3 \%$ & $0 \%$ & $0 \%$ & $3 \%$ \\
\hline Other & $6 \%$ & $0 \%$ & $0 \%$ & $3 \%$ & $0 \%$ & $7 \%$ & $2 \%$ \\
\hline
\end{tabular}

Question 17 - How many years of your life have you lived in Clackamas County?

Table 28. This table shows the responses to Question 17 as a percentage of the overall responses.

\begin{tabular}{|ll|}
\hline Time lived in Clackamas County & $\mathbf{n}=\mathbf{2 8 4}$ \\
\hline $\mathbf{1}$ - $\mathbf{2}$ years & $4 \%$ \\
$\mathbf{3}$ - 5 years & $8 \%$ \\
$\mathbf{6}$ - 10 years & $10 \%$ \\
$\mathbf{1 1}$ - 20 years & $10 \%$ \\
\hline $\mathbf{2 1}$ - $\mathbf{3 0}$ years & $19 \%$ \\
\hline More than $\mathbf{3 0}$ years & $24 \%$ \\
\hline
\end{tabular}




\section{Time lived in Clackamas County}

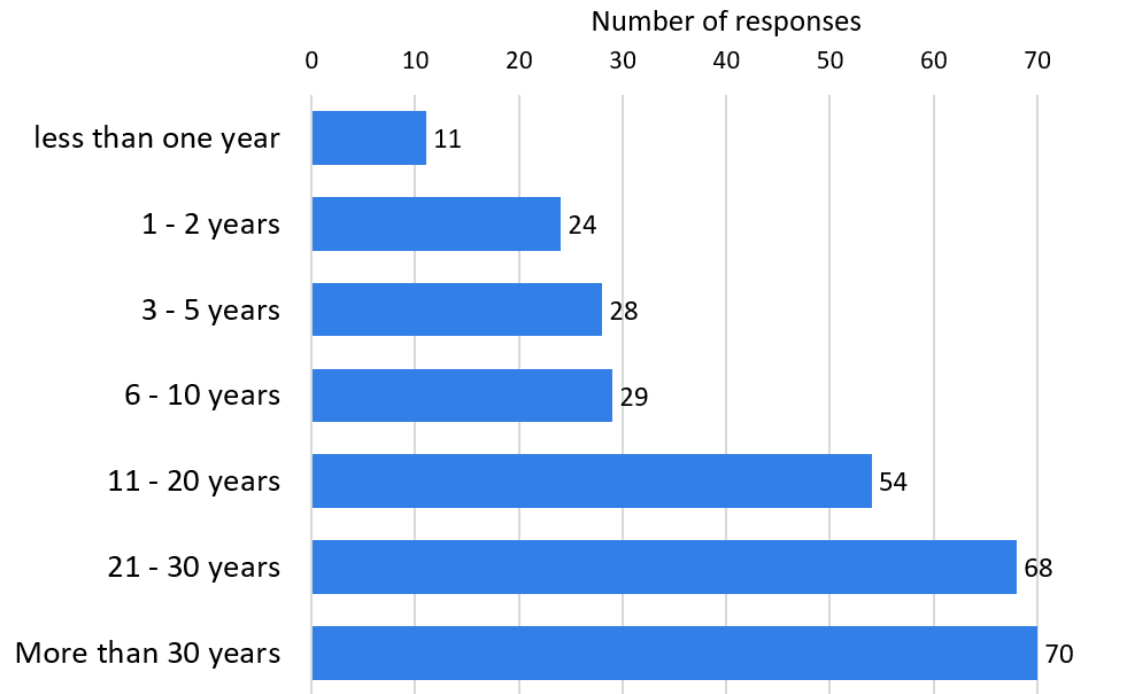

Figure 23. This figure shows the number of responses to each time period option in Question 17.

\section{Time lived in Clackamas County over 30 years}

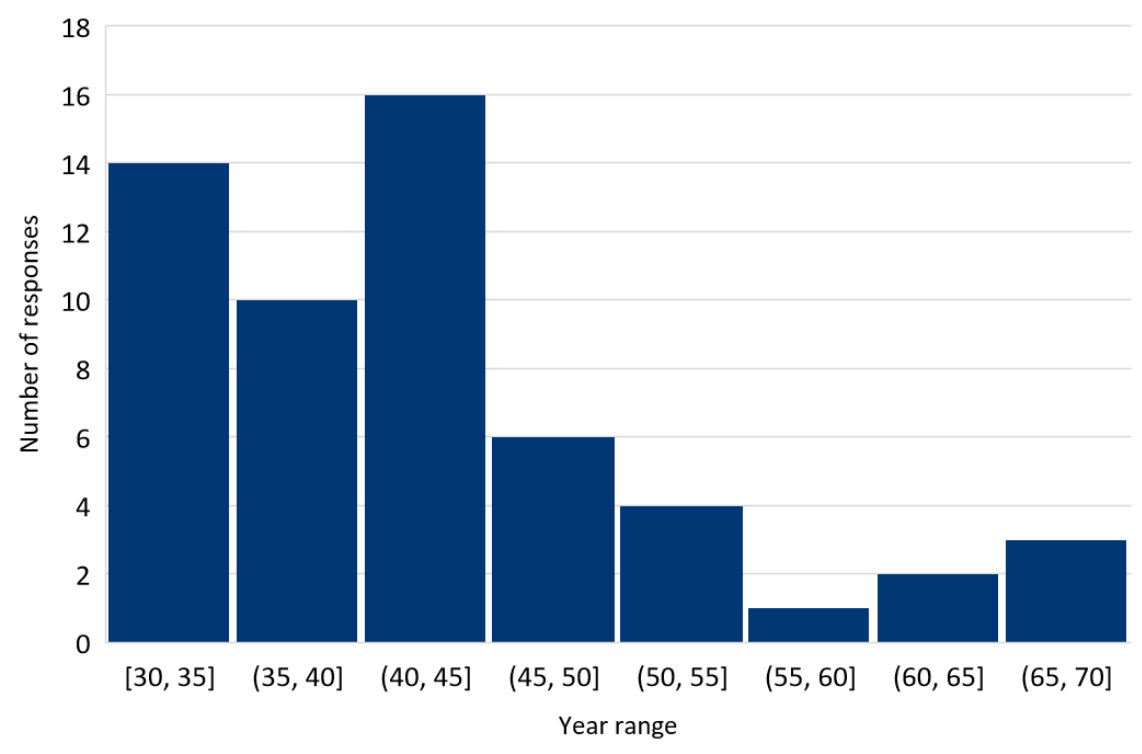

Figure 24. This histogram shows the responses of participants who have lived in Clackamas County for more than 30 years.

\section{Question 18 - Choose the option that best describes your place of residence.}

Table 29. This table shows the type of residence participants reported, by water provider group.

\begin{tabular}{|llllllll|} 
& CRW & SWA & SFWB & LO $n=31$ & OLG & TEU & Total \\
$n=50$ & $n=46$ & $n=97$ & & 940 & $n=15$ & $n=280$ \\
\hline Own & $94 \%$ & $98 \%$ & $94 \%$ & $94 \%$ & $100 \%$ & $93 \%$ & $95 \%$ \\
Rent or lease & $0 \%$ & $2 \%$ & $6 \%$ & $3 \%$ & $0 \%$ & $0 \%$ & $3 \%$ \\
\hline Other & $6 \%$ & $0 \%$ & $0 \%$ & $3 \%$ & $0 \%$ & $7 \%$ & $2 \%$ \\
\hline
\end{tabular}


Question 19 - Are you a member of a Homeowners Association (HOA), Neighborhood Association, or other similar organization?

Are you a member of a Homeowners

Association (HOA), Neighborhood Assiciation, or similar organization?

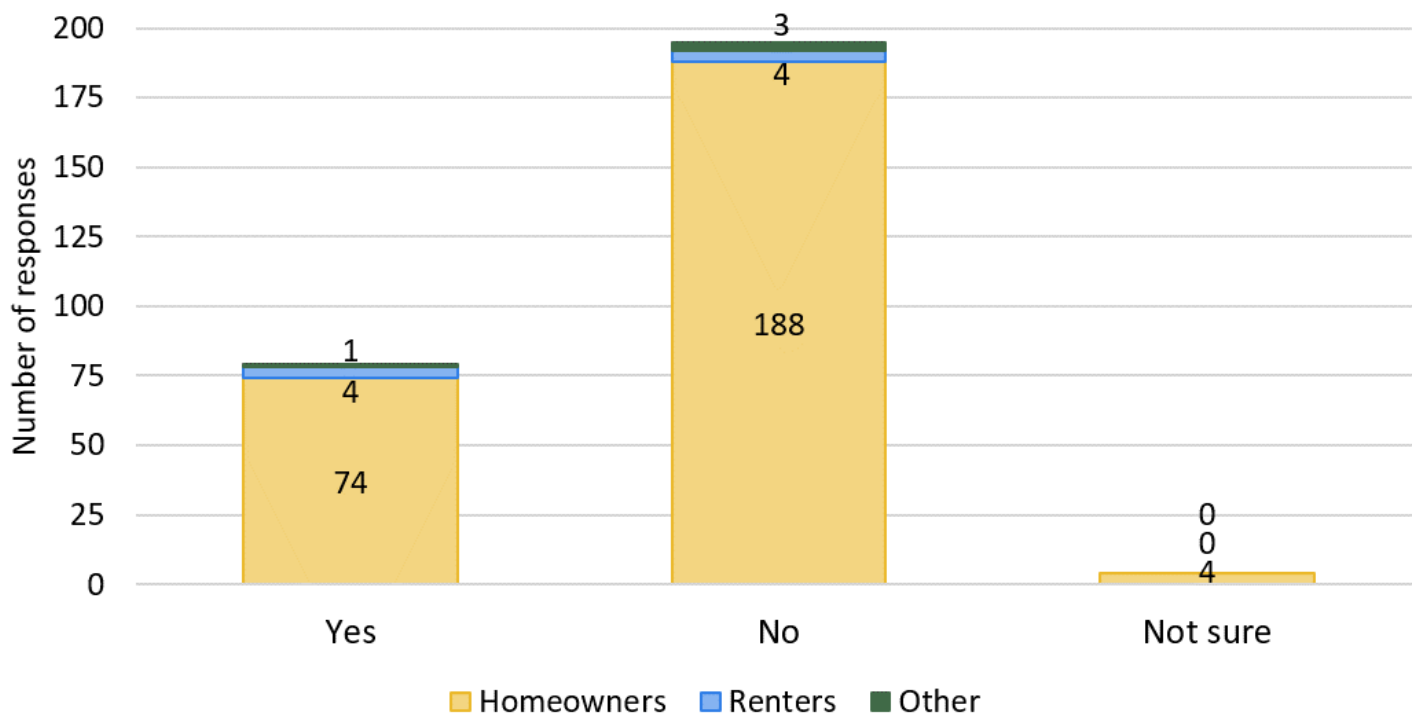

Figure 25. This figure shows the responses to Question 19, which asked if participants were part of an HOA or similar organization. It is color-coded by their residence type (responses to Question 18)

Table 30. This table shows the responses to Question 19, which asked if they were a member of an HOA. Values as percentages are listed in the last row.

\begin{tabular}{|lllll|} 
& Yes HOA & No HOA & Not sure & Total \\
\hline Homeowners & 74 & 188 & 4 & $\mathbf{2 6 6}$ \\
\hline Renters & 4 & 4 & 0 & $\mathbf{8}$ \\
Other & 1 & 3 & 0 & $\mathbf{4}$ \\
\hline Total & $\mathbf{7 9}$ & $\mathbf{1 9 5}$ & $\mathbf{4}$ & $\mathbf{2 7 8}$ \\
\hline Percentages & $\mathbf{2 8 . 5 \%}$ & $\mathbf{7 0 \%}$ & $\mathbf{1 . 5 \%}$ & $\mathbf{1 0 0 \%}$ \\
\hline
\end{tabular}

Question 20 - What is your gender?

Table 31. This table shows the percentage and number of responses to Question 20.

\begin{tabular}{|lll|}
\hline Gender & Percent & $\mathrm{n}=$ \\
\hline Female & $50 \%$ & 133 \\
\hline Male & $48 \%$ & 138 \\
Other & $3 \%$ & 7 \\
Total & & $\mathbf{2 7 8}$ \\
\hline
\end{tabular}


Question 21 - What year were you born?

Table 32. This table shows the percent of responses per age group, by water provider group.

\begin{tabular}{|c|c|c|c|c|c|c|c|}
\hline $\begin{array}{l}\text { Age } \\
\text { grouping }\end{array}$ & $\begin{array}{l}\text { CRW } \\
n=43\end{array}$ & $\begin{array}{l}\text { SWA } \\
n=43\end{array}$ & $\begin{array}{c}\text { SFWB } \\
n=87\end{array}$ & $\begin{array}{c}L O \\
n=27\end{array}$ & $\begin{array}{c}\text { OLG } \\
n=32\end{array}$ & $\begin{array}{c}\text { TEU } \\
n=16\end{array}$ & $\begin{array}{c}\text { Total } \\
n=248\end{array}$ \\
\hline $20-29$ & $0 \%$ & $2 \%$ & $1 \%$ & $4 \%$ & $0 \%$ & $0 \%$ & $1 \%$ \\
\hline $30-39$ & $16 \%$ & $14 \%$ & $17 \%$ & $0 \%$ & $13 \%$ & $25 \%$ & $15 \%$ \\
\hline $40-49$ & $14 \%$ & $23 \%$ & $22 \%$ & $11 \%$ & $22 \%$ & $38 \%$ & $21 \%$ \\
\hline $50-59$ & $19 \%$ & $23 \%$ & $15 \%$ & $37 \%$ & $25 \%$ & $19 \%$ & $21 \%$ \\
\hline $60-69$ & $42 \%$ & $30 \%$ & $28 \%$ & $26 \%$ & $25 \%$ & $13 \%$ & $29 \%$ \\
\hline $70-79$ & $7 \%$ & $7 \%$ & $16 \%$ & $19 \%$ & $13 \%$ & $0 \%$ & $12 \%$ \\
\hline $80+$ & $2 \%$ & $0 \%$ & $1 \%$ & $4 \%$ & $3 \%$ & $6 \%$ & $2 \%$ \\
\hline Median & 60 & 52.5 & 56 & 59 & 58 & 42 & 56 \\
\hline
\end{tabular}

Age distribution

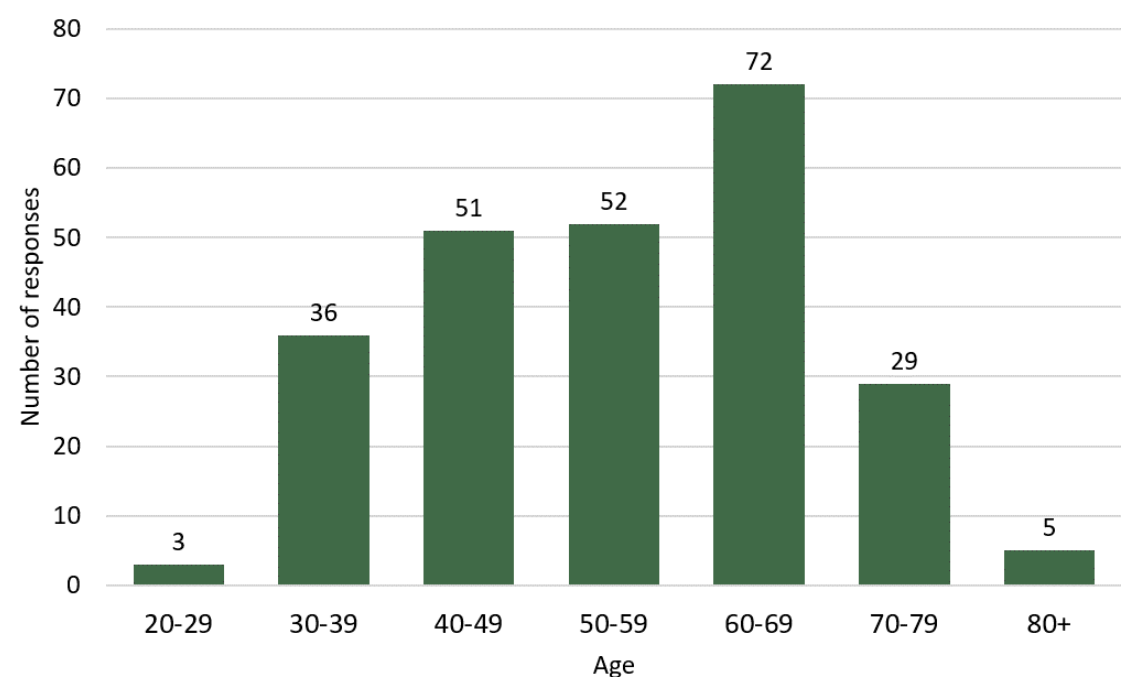

Figure 26. This histogram shows the overall age distribution of survey participants.

Question 22-What is the highest level of school you have completed?

\section{Education}

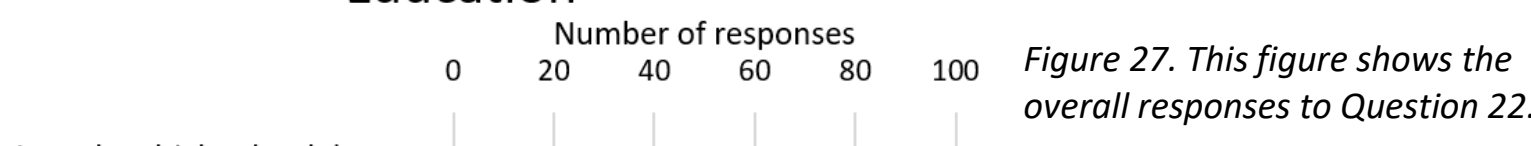

High school diploma or equivalent

Some college, no degree

12

Associate's degree (2 yr)

Bachelor's degree (4 yr)

27

Bachelor's degree $(4 \mathrm{yr})$

Graduate or professional degree

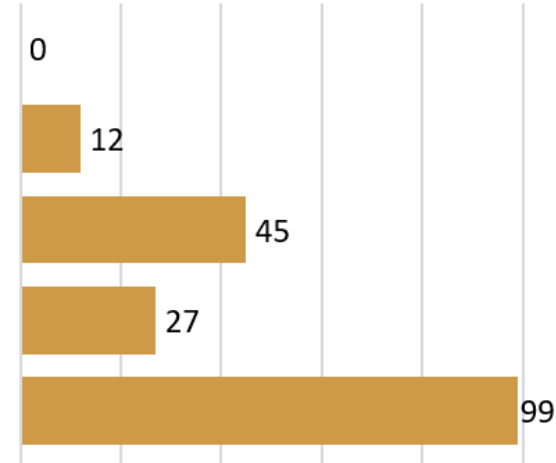

overall responses to Question 22. 
Table 33. This table shows the percent of responses for Question 22.

\begin{tabular}{|lr|}
\hline Education & $\%$ of Responses \\
\hline Less than High School degree & $0 \%$ \\
\hline High School degree or equivalent & $4 \%$ \\
\hline Some college, no degree & $16 \%$ \\
\hline Associate's degree (2 yr) & $10 \%$ \\
\hline Bachelor's degree (4 yr) & $36 \%$ \\
\hline Graduate or professional degree & $33 \%$ \\
\hline Total & $\mathbf{2 7 5}$ \\
\hline
\end{tabular}

Question 23 - Please estimate your 2019 total household income before taxes.

Annual Household Income

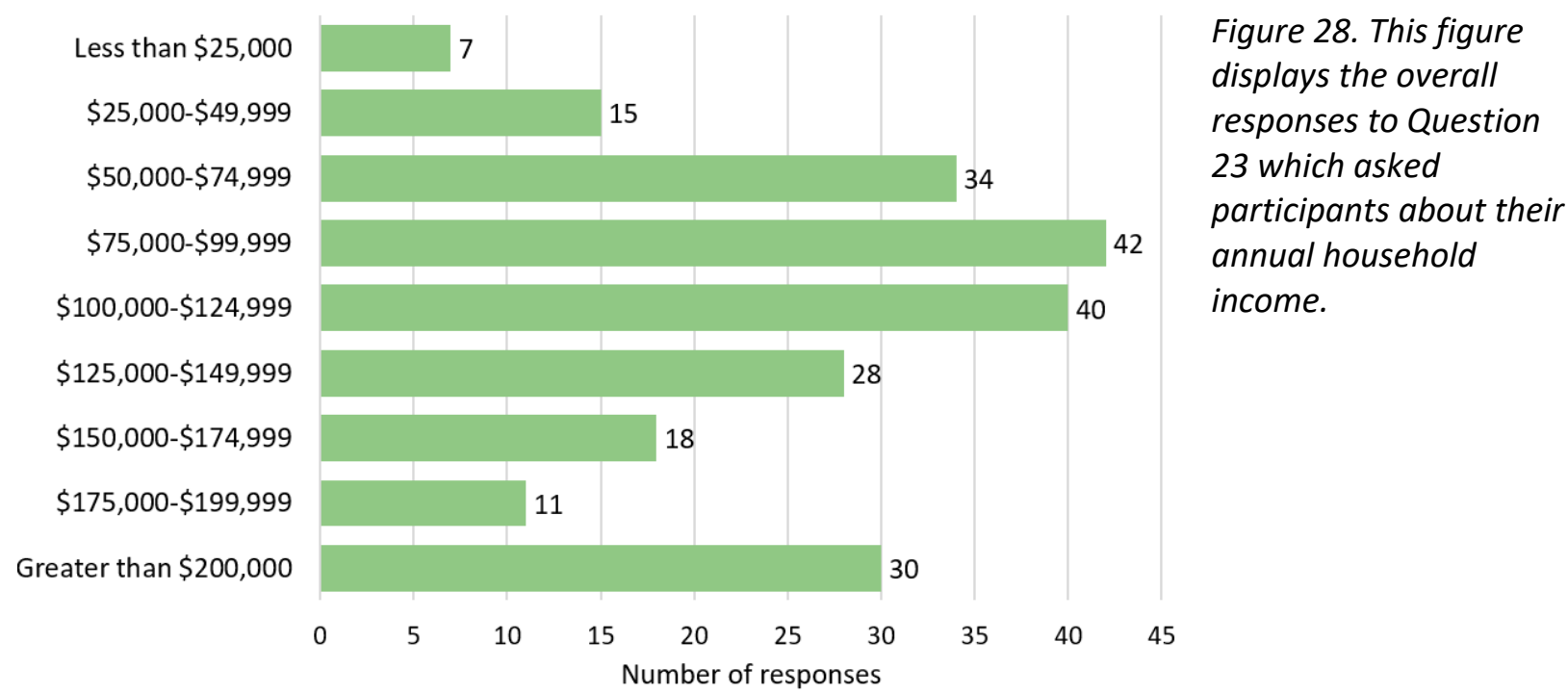

Table 34. This table shows the responses to Question 23 as percentages of the total.

\begin{tabular}{|ll|}
\hline Income & Percent \\
\hline $\mathbf{\$ 2 5 , 0 0 0 - \$ 4 9 , 9 9 9}$ & $3 \%$ \\
$\mathbf{\$ 5 0 , 0 0 0 - \$ 7 4 , 9 9 9}$ & $7 \%$ \\
\hline $\mathbf{\$ 7 5 , 0 0 0 - \$ 9 9 , 9 9 9}$ & $15 \%$ \\
\hline $\mathbf{\$ 1 0 0 , 0 0 0 - \$ 1 2 4 , 9 9 9}$ & $19 \%$ \\
\hline $\mathbf{\$ 1 2 5 , 0 0 0 - \$ 1 4 9 , 9 9 9}$ & $18 \%$ \\
\hline $\mathbf{\$ 1 5 0 , 0 0 0 - \$ 1 7 4 , 9 9 9}$ & $12 \%$ \\
\hline $\mathbf{\$ 1 7 5 , 0 0 0 - \$ 1 9 9 , 9 9 9}$ & $8 \%$ \\
\hline Greater than $\mathbf{\$ 2 0 0 , 0 0 0}$ & $5 \%$ \\
\hline Total & $13 \%$ \\
\hline
\end{tabular}




\section{Question 24 - Please select one option to rate whether you consider your political} attitudes to be more conservative or more liberal in nature.

\section{Political leanings}
Very liberal
Somewhat liberal
Neither conservative or liberal
Somewhat conservative
Very conservative

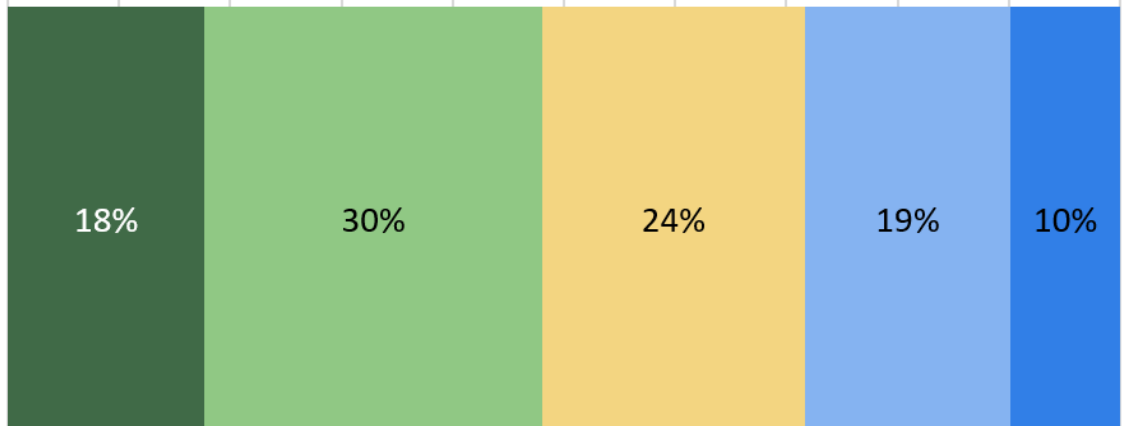

Figure 29. This figure shows the participants' reported political identity.

Table 35. This table displays the political identities of the participants as percentages within each water provider group.

\begin{tabular}{|llllllll|} 
& CRW & SWA & SFWB & LO & OLG & TEU & Total \\
& $n=46$ & $n=45$ & $n=88$ & $n=26$ & $n=34$ & $n=15$ & $n=254$ \\
\hline Very liberal & $7 \%$ & $16 \%$ & $20 \%$ & $23 \%$ & $26 \%$ & $13 \%$ & $18 \%$ \\
Somewhat liberal & $37 \%$ & $22 \%$ & $31 \%$ & $42 \%$ & $12 \%$ & $53 \%$ & $30 \%$ \\
Neither conservative or liberal & $26 \%$ & $27 \%$ & $23 \%$ & $19 \%$ & $21 \%$ & $27 \%$ & $24 \%$ \\
Somewhat conservative & $20 \%$ & $22 \%$ & $15 \%$ & $12 \%$ & $32 \%$ & $7 \%$ & $19 \%$ \\
Very conservative & $11 \%$ & $13 \%$ & $11 \%$ & $4 \%$ & $9 \%$ & $0 \%$ & $10 \%$ \\
\hline
\end{tabular}

Table 36. This table shows the mean motivation rating ( 0 being the lowest, 4 being the highest) of each political identity, the percent of all participants who marked "Definitely yes" to any of the actions provided in Question 12, and the percent of participants who requested information in Question 15.

\begin{tabular}{|lrrrr|} 
& $\begin{array}{r}\text { Motivation } \\
\text { mean }\end{array}$ & $\begin{array}{r}\text { Yes } \\
\text { Action }\end{array}$ & $\begin{array}{r}\text { Request } \\
\text { Info }\end{array}$ & $\mathrm{n}=$ \\
\hline Very liberal & 2.40 & $62 \%$ & $42 \%$ & 45 \\
Somewhat liberal & 2.24 & $42 \%$ & $39 \%$ & 77 \\
Neither conservative or & 1.97 & $48 \%$ & $23 \%$ & 60 \\
liberal & 1.78 & $36 \%$ & $23 \%$ & 47 \\
Somewhat conservative & 1.56 & $40 \%$ & $24 \%$ & 25 \\
Very conservative & $\mathbf{2 . 0 5}$ & $\mathbf{4 6 \%}$ & $\mathbf{3 1 \%}$ & $\mathbf{2 5 4}$ \\
\hline Average & & & &
\end{tabular}




\section{References}

1. Clackamas River Water Providers | About Us [Internet]. [cited 2019 Nov 23]. Available from: https://www.clackamasproviders.org/about-us/

2. Chen J, Chang H. Climate and Land Use Change Impacts on Water Quality and Quantity - Clackamas Watershed Resilience Project (Poster) [Internet]. Portland State University, Department of Geography; 2019 May [cited 2019 Aug 6]. Available from: https://drive.google.com/file/d/1uQszJvFfON1S5Ct9wN2lalq20okPN9Q/view?usp=embed_facebook

3. Chen J, Chang H. Projected Changes in river discharge and sediment load in Clackamas River Watershed [Internet]. Portland State University, Department of Geography; 2019 May [cited 2019 Aug 6]. Available from: https://drive.google.com/file/d/1cV4Jho1XnepwynErHf935eYrlOxqKBl8/view?usp=embed_facebook

4. Clackamas River Water Providers | Fish On The Run [Internet]. 2019 [cited 2019 Aug 6]. Available from: https://www.clackamasproviders.org/water-conservation/fish-on-the-run/

5. Ajzen I. The theory of planned behavior. Organizational Behavior and Human Decision Processes. 1991 Dec 1;50(2):179-211.

6. Rogers EM. Diffusion of Innovations. Free Press; 1983.

7. Clackamas County, OR | Data USA [Internet]. [cited 2020 May 22]. Available from: https://datausa.io/profile/geo/clackamas-county-or\#about

8. Larson D. Attitudes, Behaviors, and Archetypes in the Clackamas River Basin: A Model for Water Customer Analysis and Outreach for Watershed Protection and Conservation [Dissertation]. Portland State University; 2019.

9. Hurlimann A, Dolnicar S. Voluntary relocation - An exploration of Australian attitudes in the context of drought, recycled and desalinated water. Global Environmental Change. 2011 Aug 1;21(3):108494.

10. March H, Saurí D, Olcina J. Rising temperatures and dwindling water supplies? Perception of climate change among residents of the Spanish Mediterranean tourist coastal areas. Environ Manage. 2014 Jan;53(1):181-93.

11. Liang Y (Jake), Henderson LK, Kee KF. Running Out of Water! Developing a Message Typology and Evaluating Message Effects on Attitude Toward Water Conservation. Environmental Communication. 2018 May 19;12(4):541-57. 